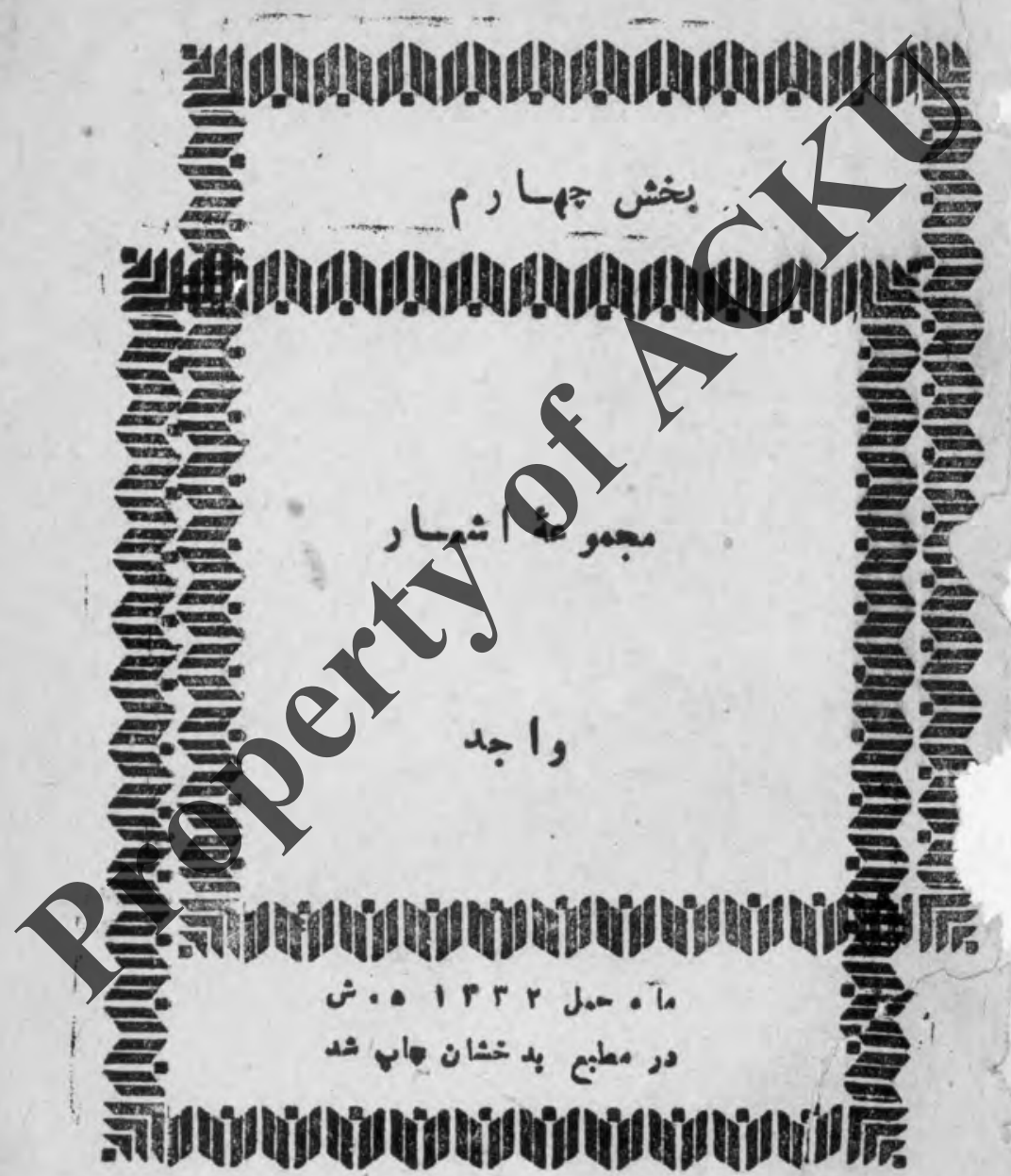




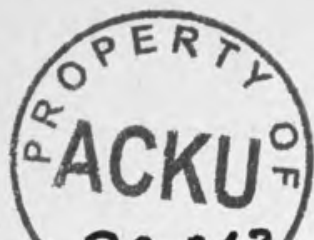

32213

雚

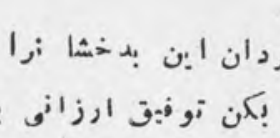

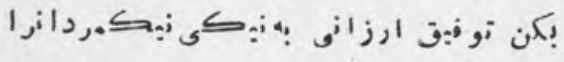

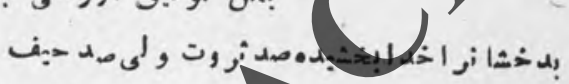

أنى

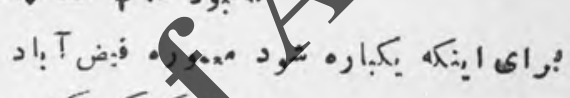

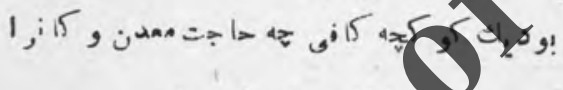

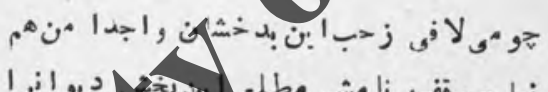

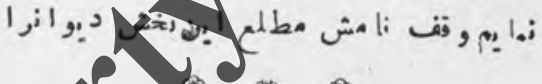

人र

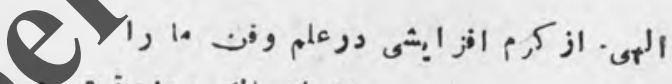

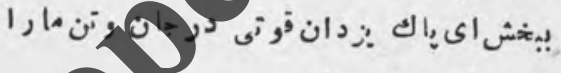

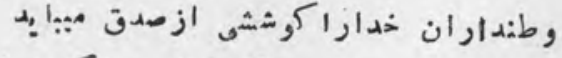

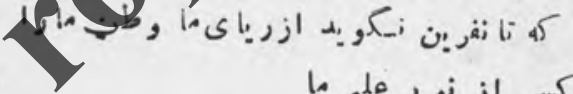

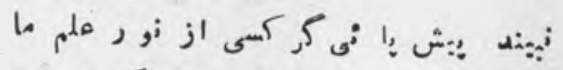

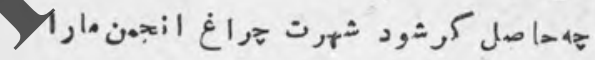

$$
\text { كنمبمازروى حاجت وارد ازأهريكه غله باز }
$$

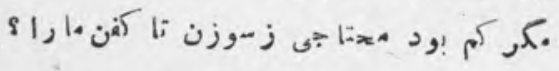

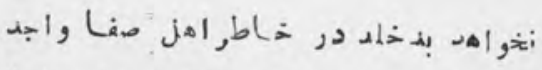

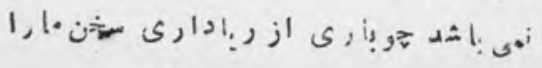




$$
=r=
$$

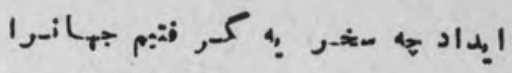

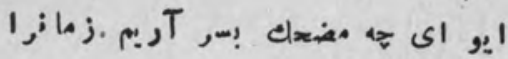

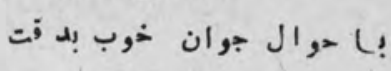

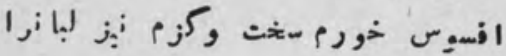

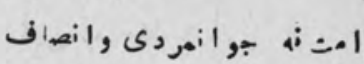

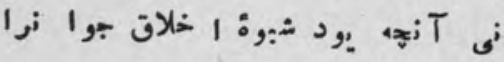

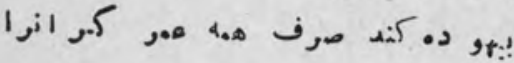

:

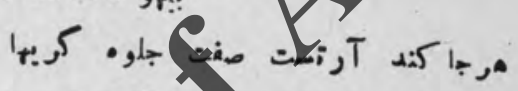

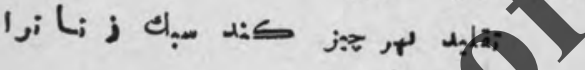

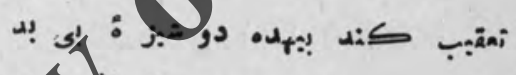

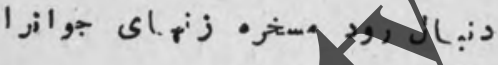

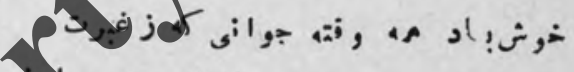

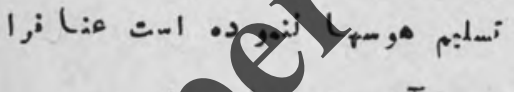

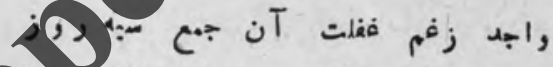

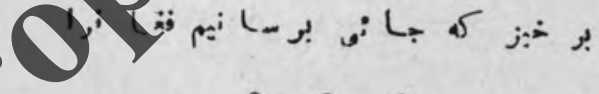

- 0

بكث:ـا ند هم درد عثق سو زا زرا

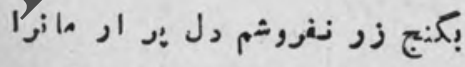

$$
\text { بر دلبست ^رابيخ:ر زك:ف و صل }
$$

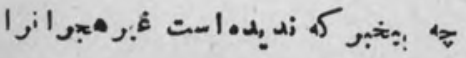

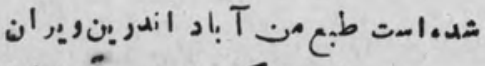

$$
\begin{aligned}
& \text { ازان م:شه دعا كو بماين بدخثا نرا }
\end{aligned}
$$




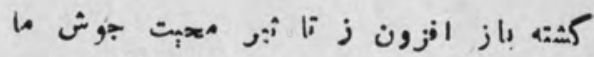

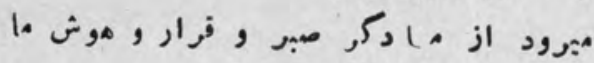

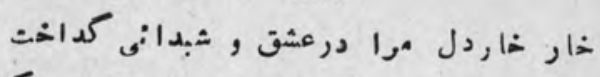

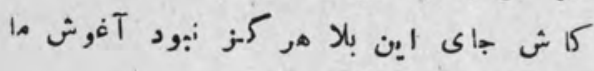

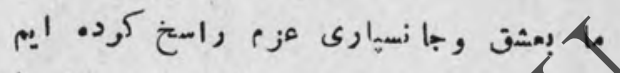

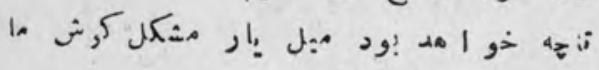

$$
\text { | }
$$

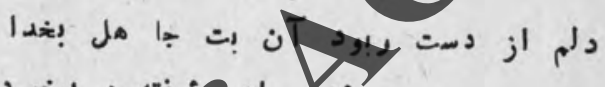

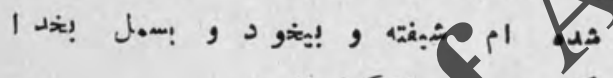



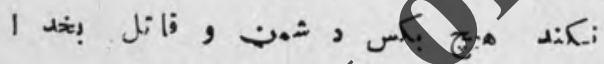

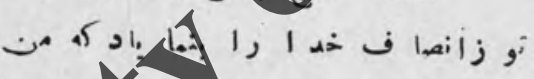

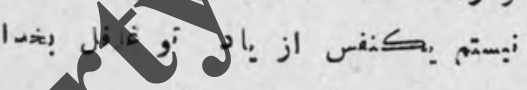

(1)

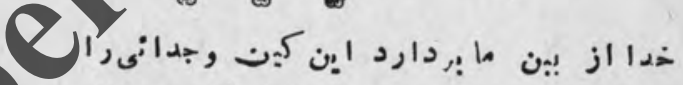

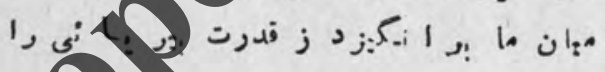

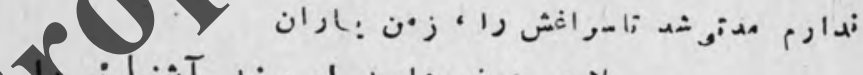

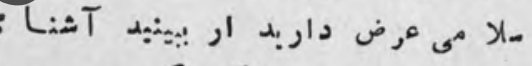

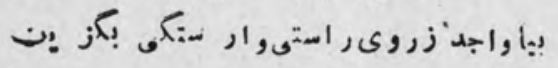

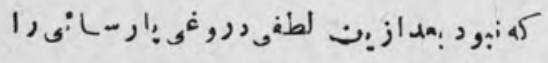

(1)

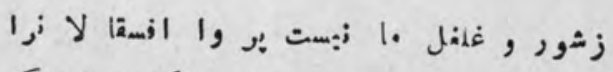

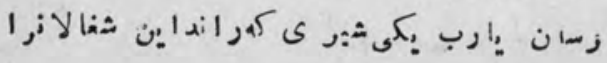




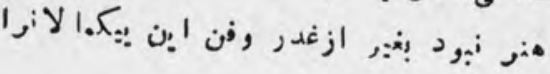

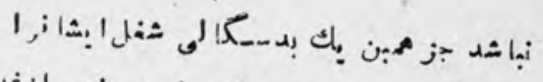

!t

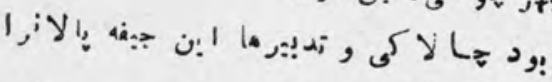

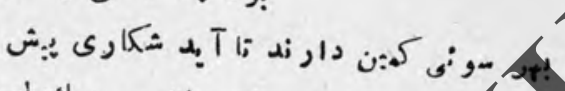

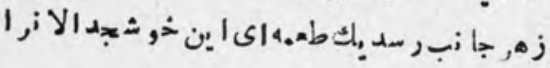

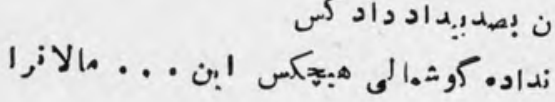

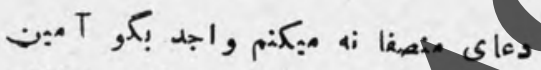

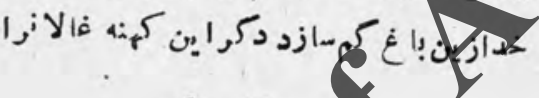

(9)

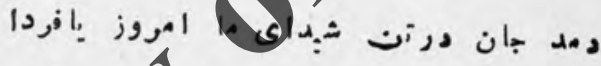

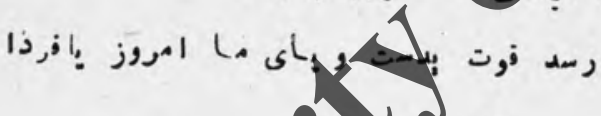

人)

T-

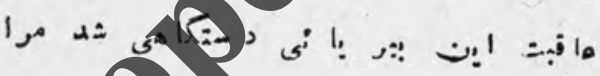

중

خيا ات زابرد ش:با زحشهم خواب ش:رين را

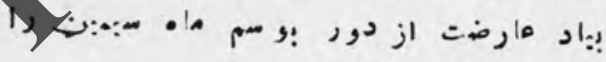

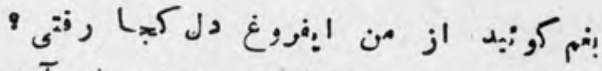

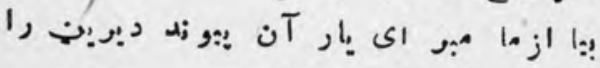

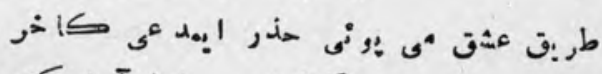

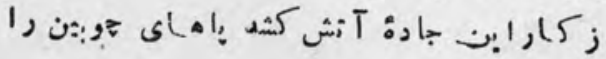




$$
\begin{aligned}
& =0
\end{aligned}
$$

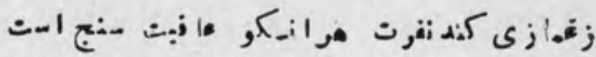

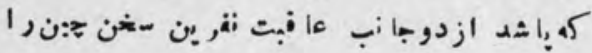

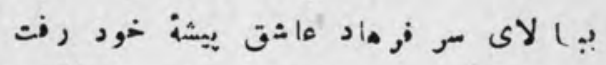

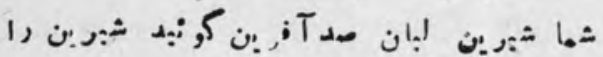

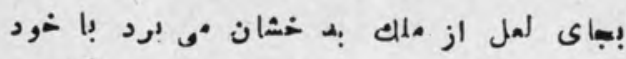

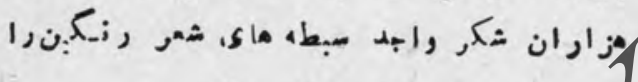

- 둔

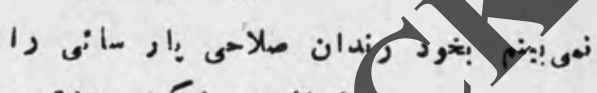

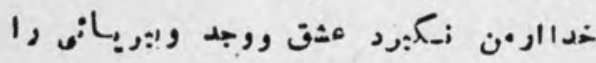
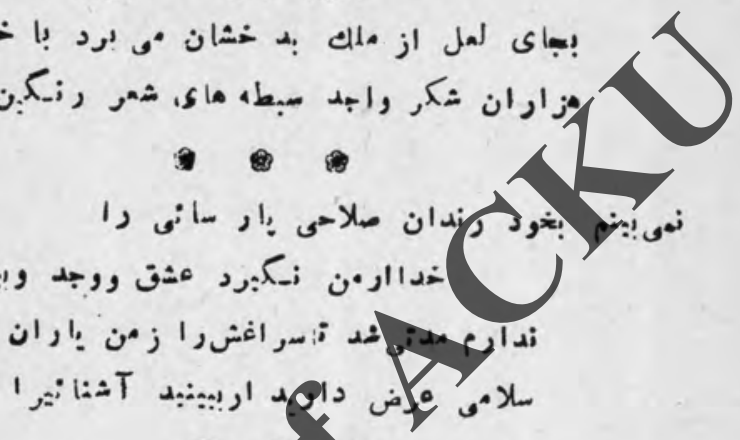

8

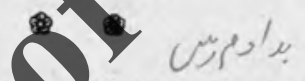

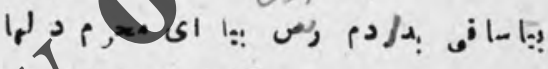

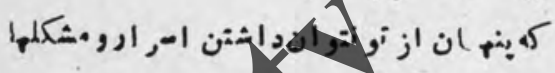

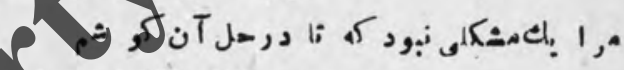

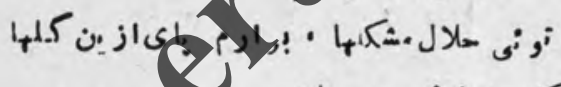

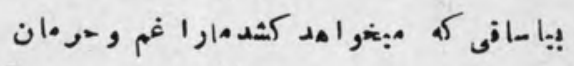

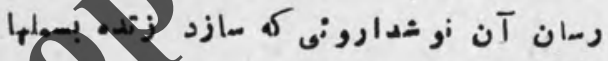

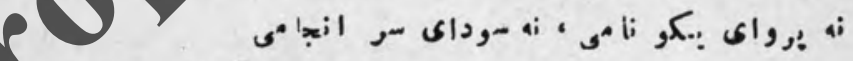

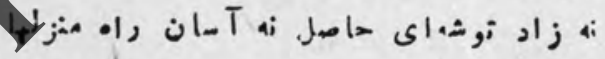

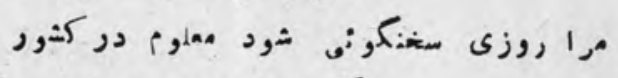

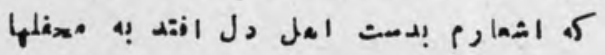

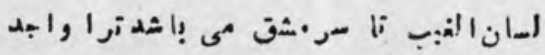

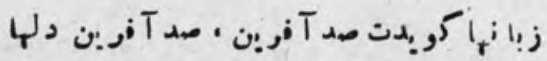

- 
L.

$$
\begin{aligned}
& \text { (2) }
\end{aligned}
$$

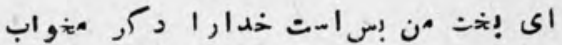

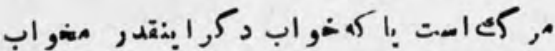

(2)

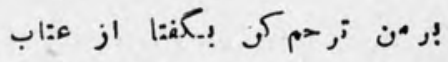

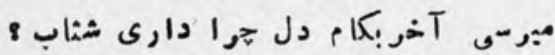

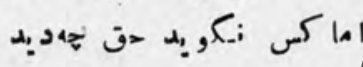

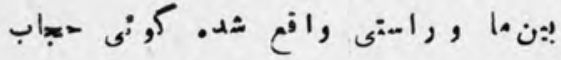

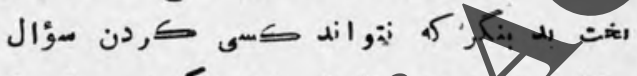

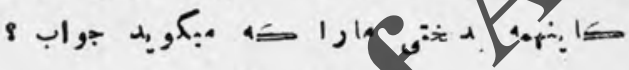

(6)

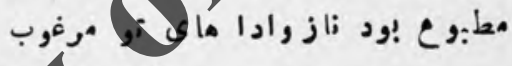

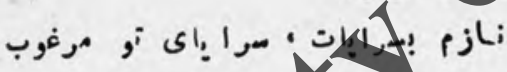

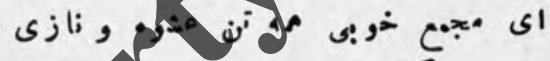

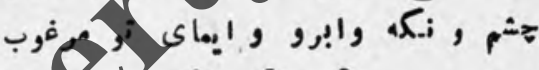

$$
\text { (3) }
$$

! اع:بار دو روزى اه:بار

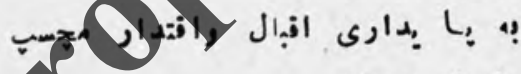

$$
\text { بهال وجاه دن خويش را بخ:ره •بته }
$$

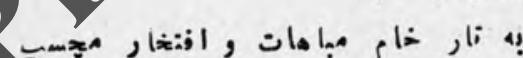

$$
\text { بدام iفس وهوى كير ه:شوى تحو هكس }
$$

جو ه:

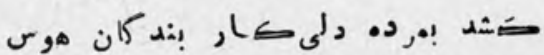

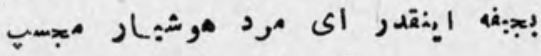

$$
\begin{aligned}
& \text { (2) }
\end{aligned}
$$




$$
=V=
$$

سخت بدفسهت كه ا!ن هاك بد خشان بوده است

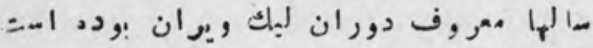

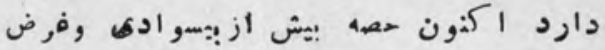

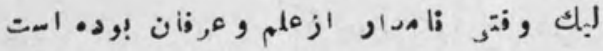

هركم حسب طا فت ازدل كرد خدهت بهرفوم

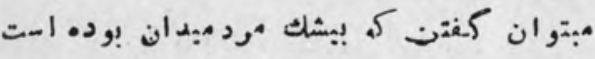

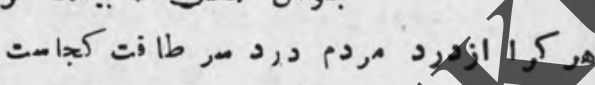

بار غم :ردن م:شه كار هردان :وده است

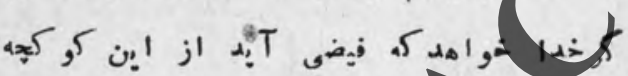

ه

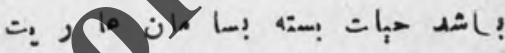

$\because$, le ن ن ;

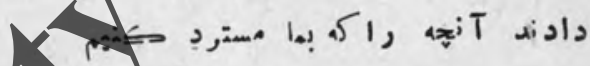

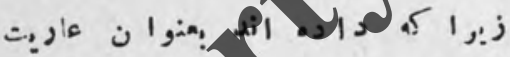

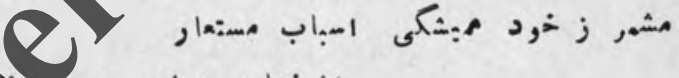

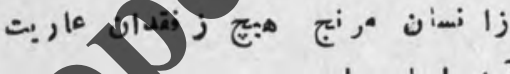

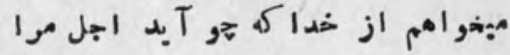

به:

$$
\begin{aligned}
& \text { واجد Aشو قسرده اك كر فى الهثل بn+ر }
\end{aligned}
$$

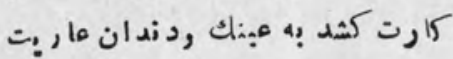

(2)

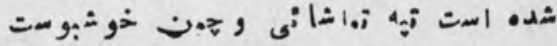

زجوش لاله خراغان بيام و در هرسوست 


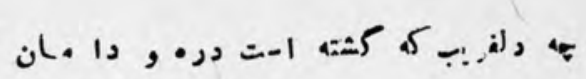

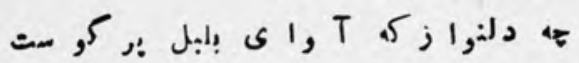

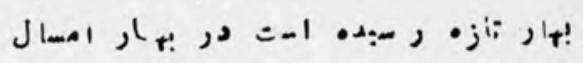

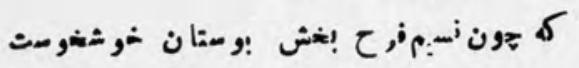

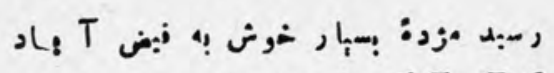

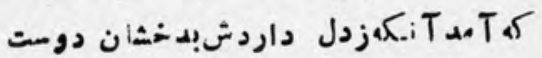

-

ت-1

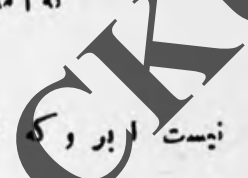

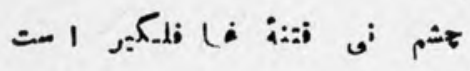

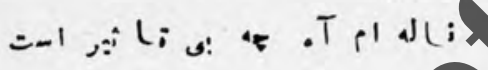

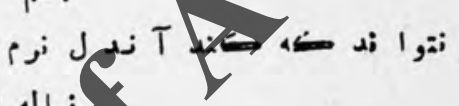

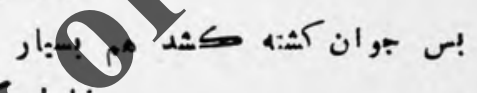

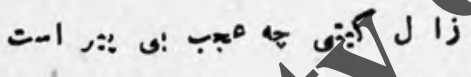

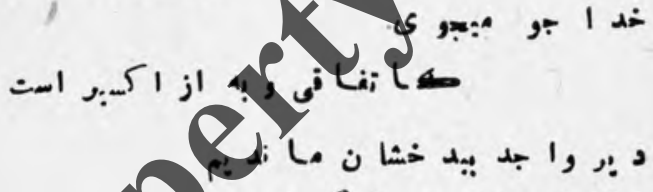

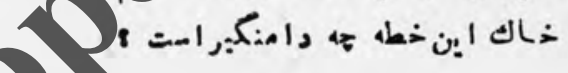

\section{- -}

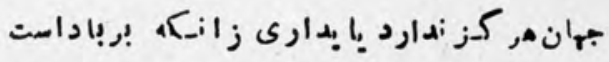

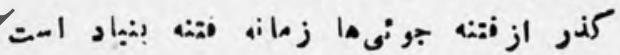

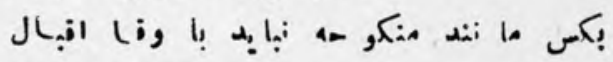

بحاتز

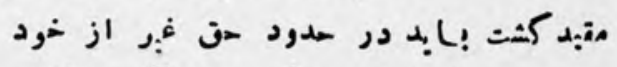

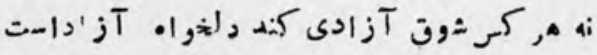




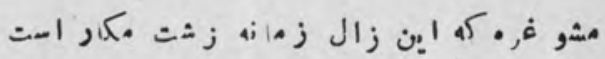

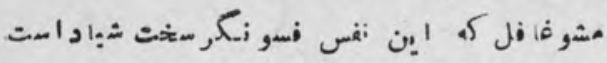

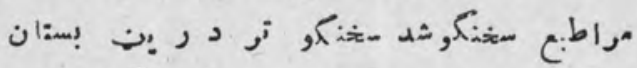

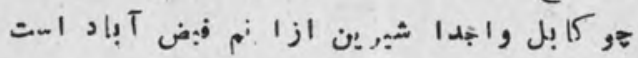

(8)

: آبكوشار رسانى داد و بيدادت

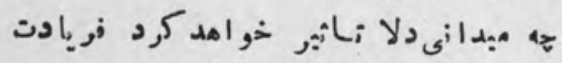

:

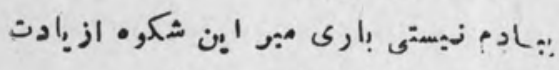

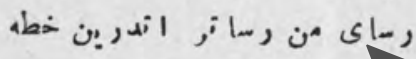

شوى

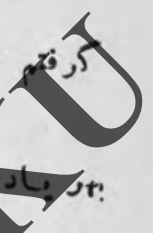

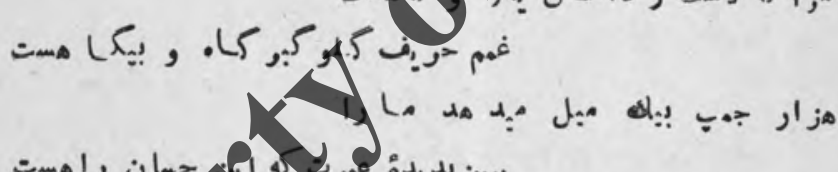

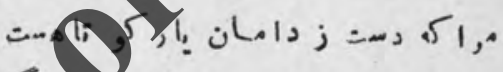

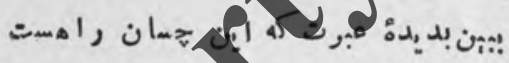

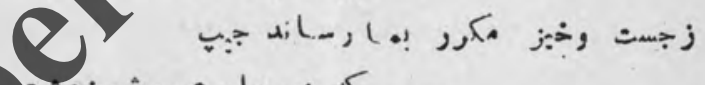

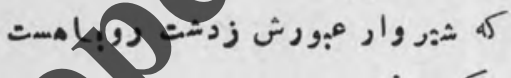

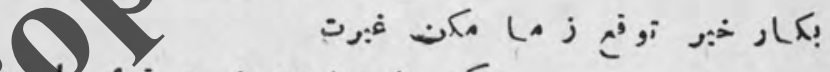

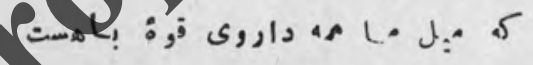

$$
\begin{aligned}
& \text { كس:كه لاف ز ز }
\end{aligned}
$$

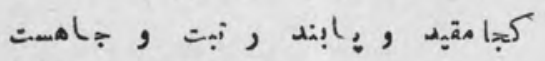

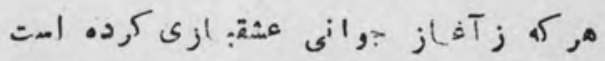

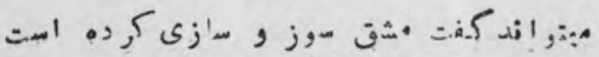




$$
=1 \cdot=
$$

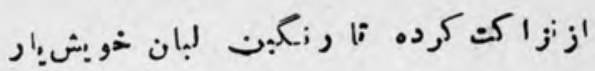

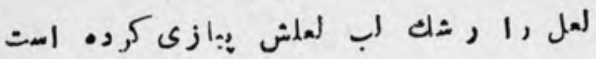

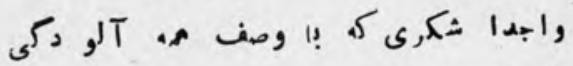

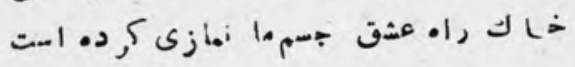

جن

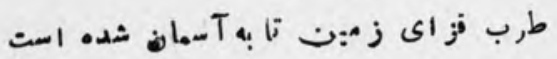

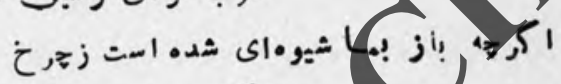

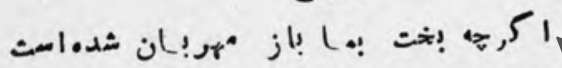

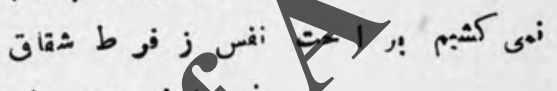

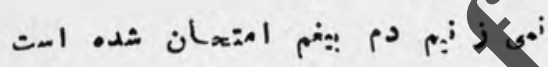

دو ا-ه:

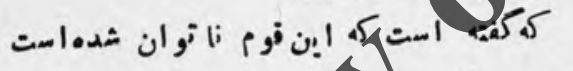

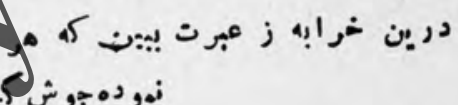

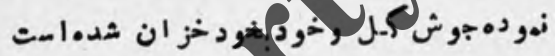

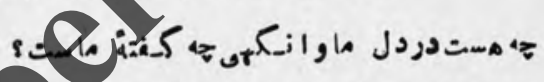

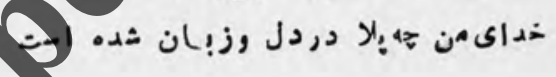

در بن زها نه كه نظهش بكار ب:ثو ند است

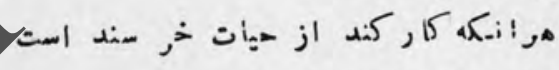

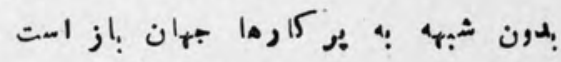

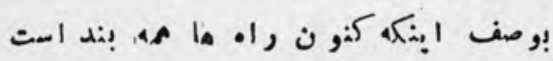

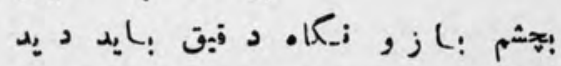

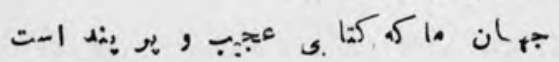


$-11=$

كSى ز

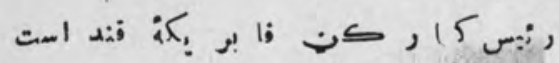

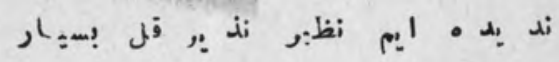

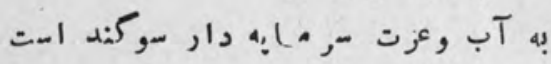

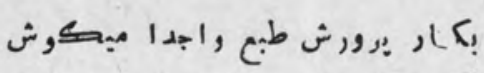

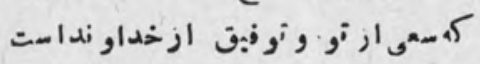

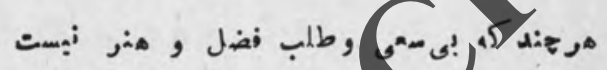

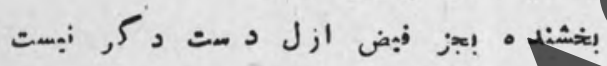

•:

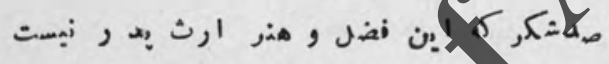

كو نى ز

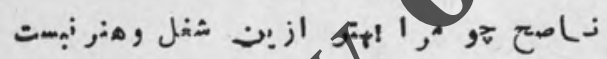

اAروز خر ى كث:4

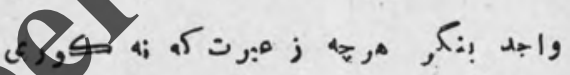

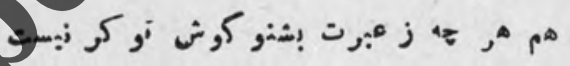

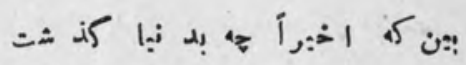

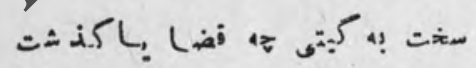

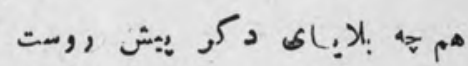

I

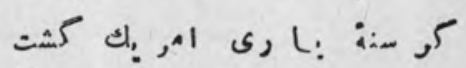

$=0$ 


$$
=15=
$$

لوربر عشق ;, بسو :بحث ر شور

!:ن •ن وابن ول ول شيدا كـذ شت

دوش مى ك.فت جوا نى ز زبد

,

גis

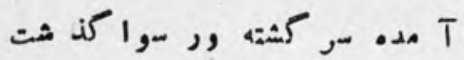

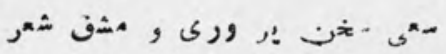

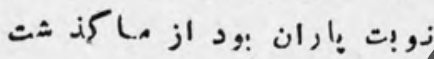

شد درون أتسر Tكآ آش كجا ست

:

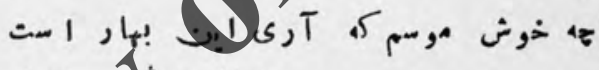

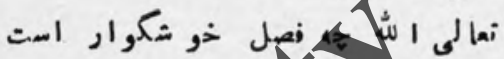

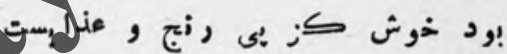

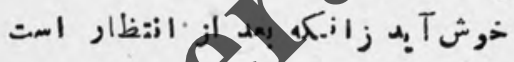

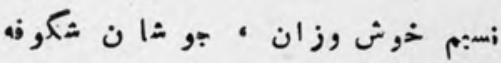

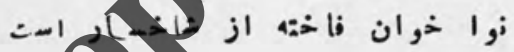

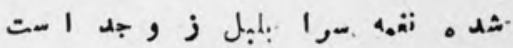

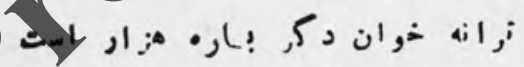

ز هر سو نى هز ار Tه:ك

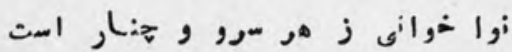

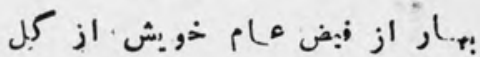

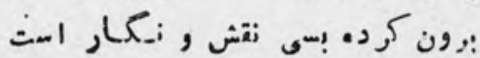




$$
\begin{aligned}
& -\operatorname{lr}= \\
& \text { د, ال , بام هر آباد , ويران }
\end{aligned}
$$

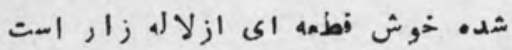

$$
\text { جه زيبا كشثه طرف انغ و, راغست }
$$

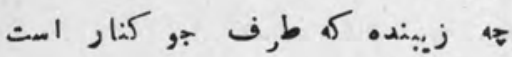

$$
\text { مان }
$$

جه روح انزا صـداى آبشار است

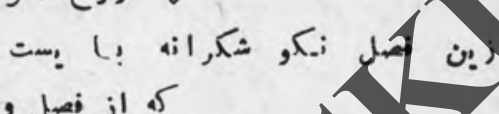

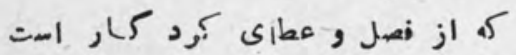

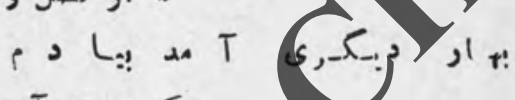

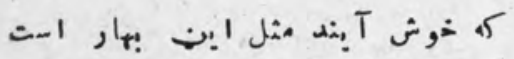

$$
\text { شبإب آ }
$$

每

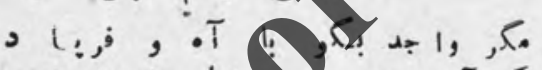

$$
\begin{aligned}
& \text { ك }
\end{aligned}
$$

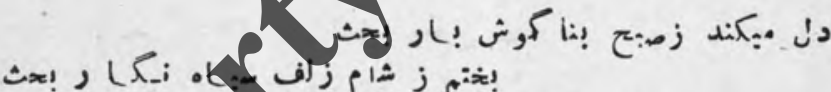

$$
\text { Q }
$$

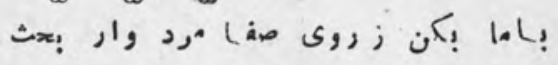

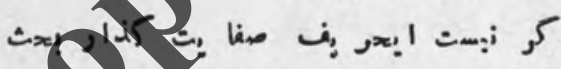

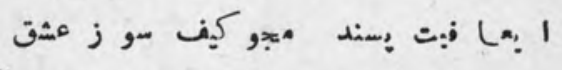

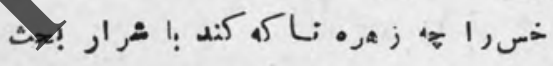

$$
\text { خا }
$$

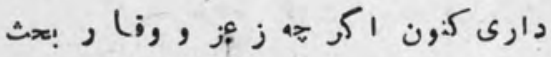

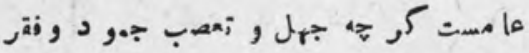

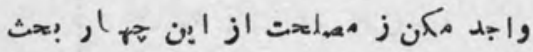

$$
\text { 영 } 8
$$




$$
=12=
$$

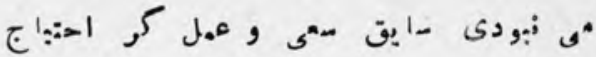

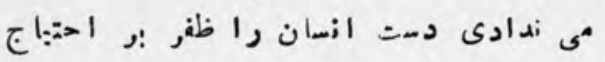

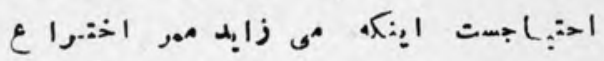

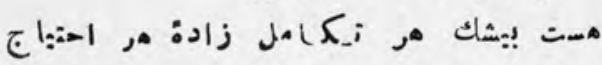

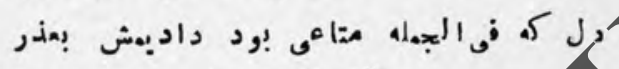

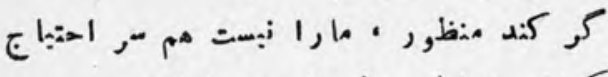

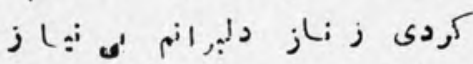

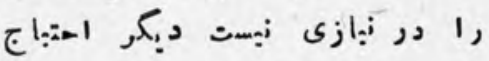

面

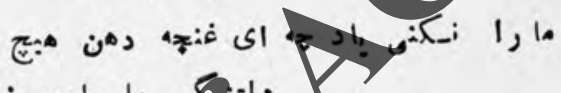

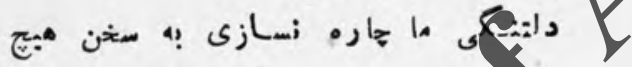

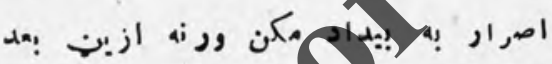

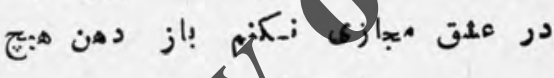

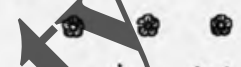

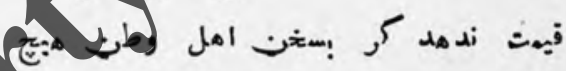

E:

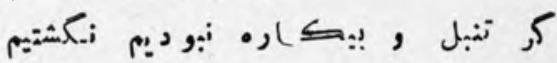

إز

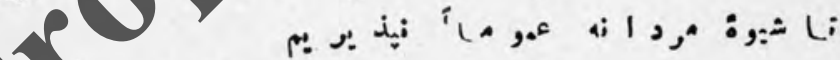

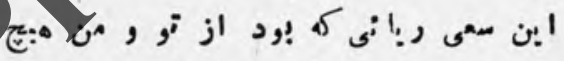

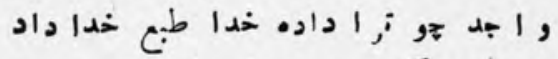

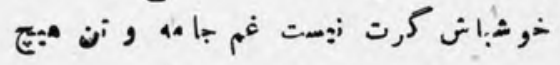

(1) (1)

بر خيز زخواب iiز - كن رو بخدا در صبح

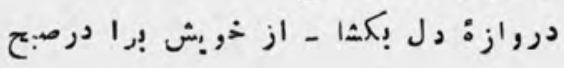




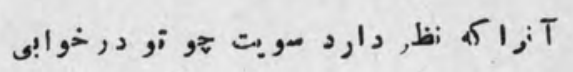

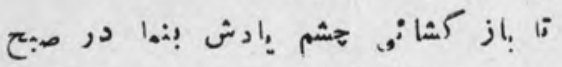

$$
\text { إى تشنه لب رح.ت - زانجه بودت مطنوب }
$$

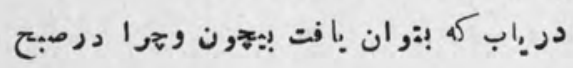

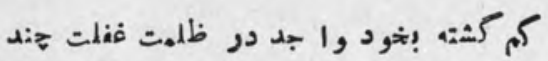

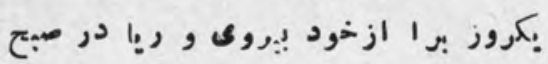

2.

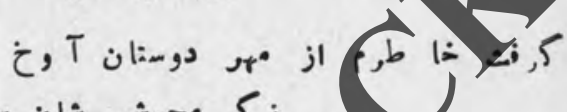

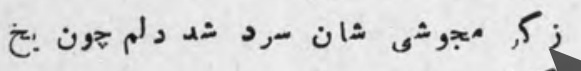

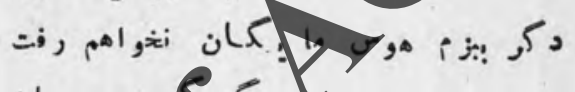

خ

$$
\text { Li L. ن }
$$

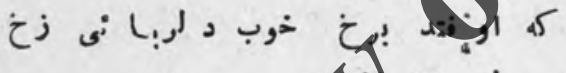

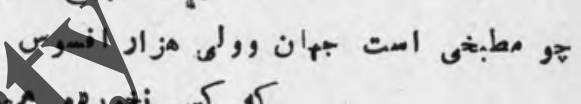

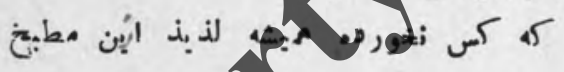

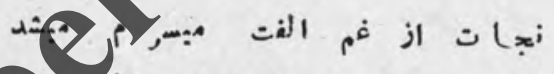

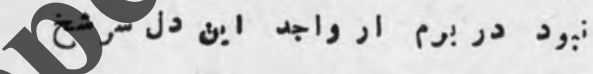

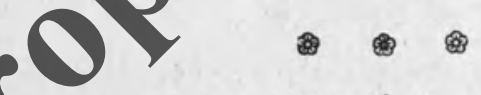

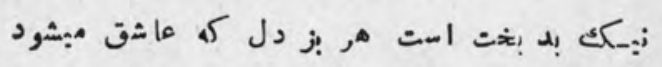

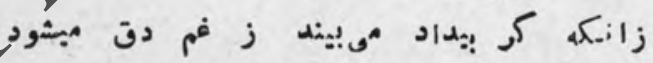

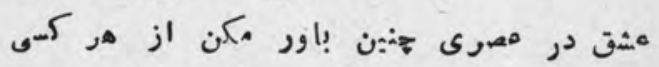

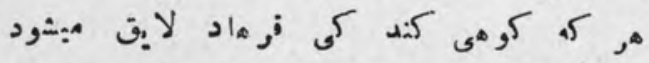

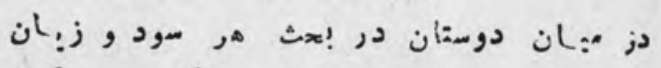

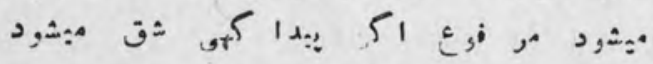




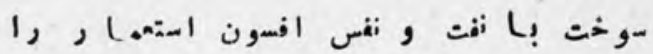

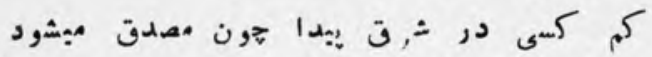

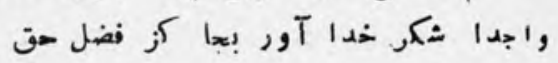

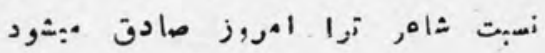

(․ㅜ

من

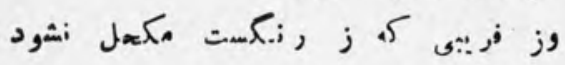

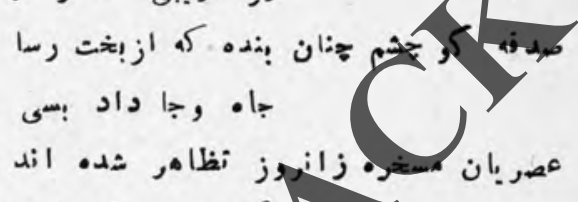

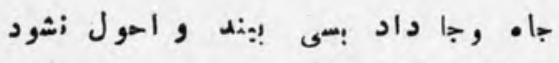

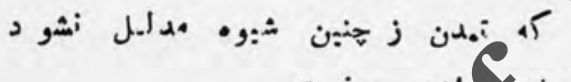
ج:ش طبش

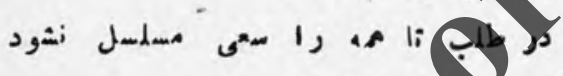

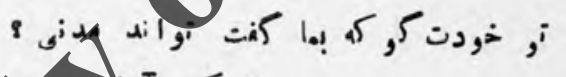

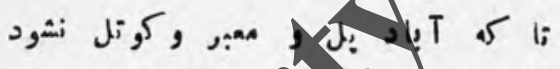

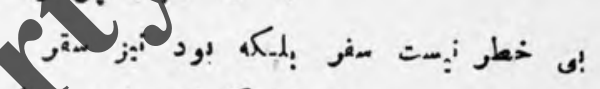

2.

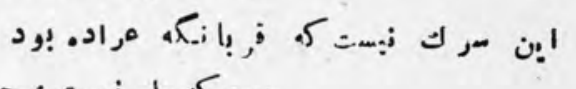

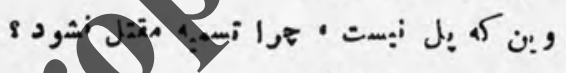

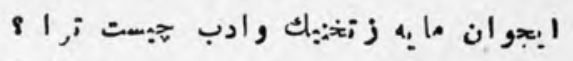

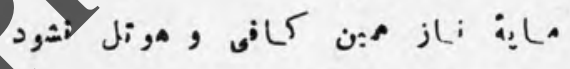

كار وان بشرى ب:ش رود هرشب ور روز

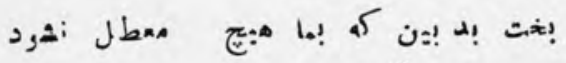

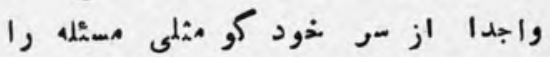

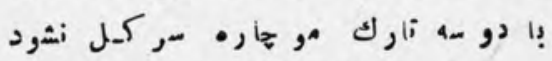

(1) 뭉 


$$
=\mid v=
$$

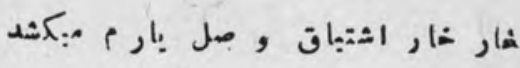

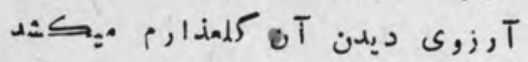

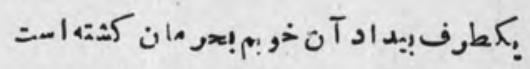

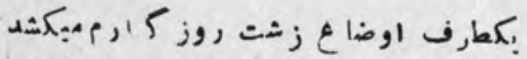

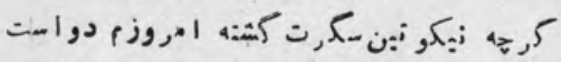

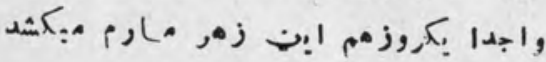

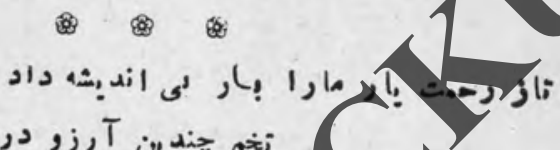

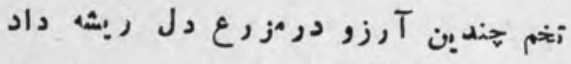

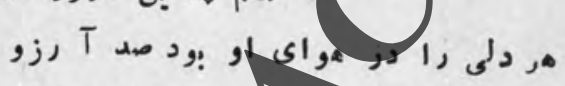

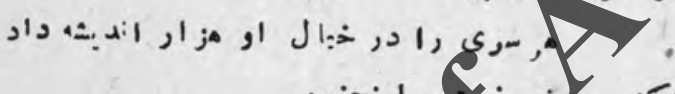

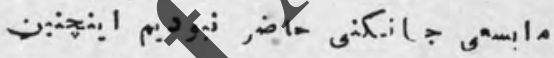

:

$$
\text { كان }
$$

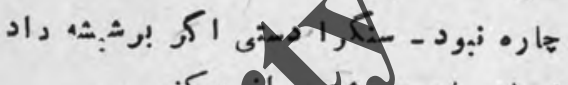

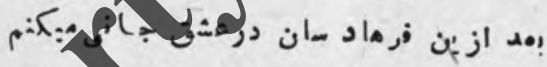

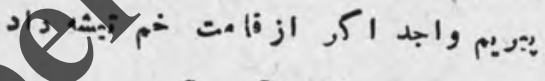

*3 8

• رخت

\section{(1)}

di l l la la

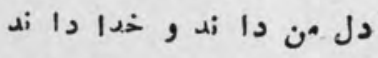

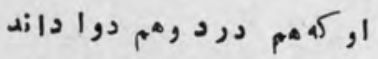

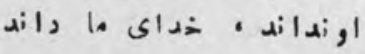

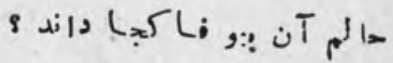

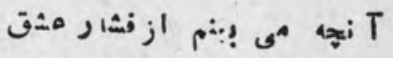

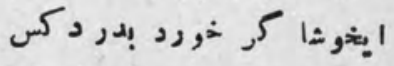
دوست داريم بخترش ازئان 


$$
=11=
$$

$$
\begin{aligned}
& \text { أو جه دانى د لاكه آن مغر ور }
\end{aligned}
$$

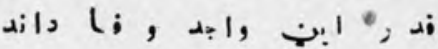

(8) क

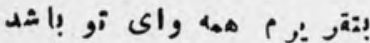

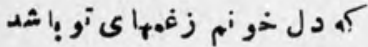

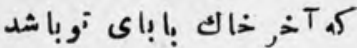

غم اثر وز وفرداى تو باشيد

بسر بسئر سوداى أو باشه ت 死

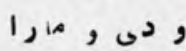

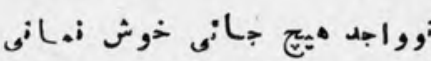

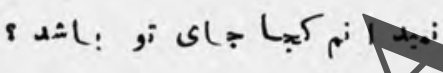

(2)

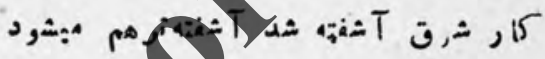

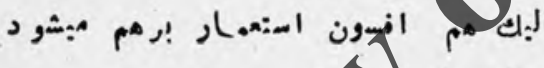

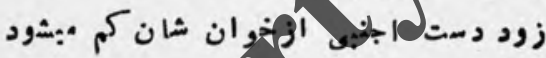

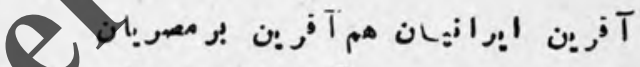

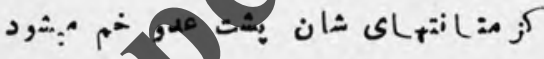

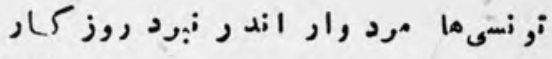

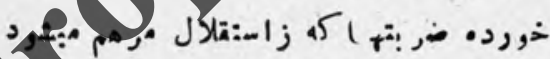

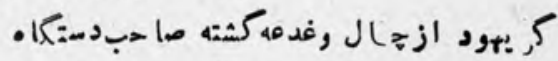

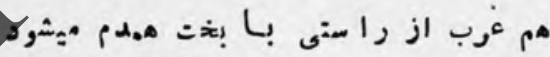

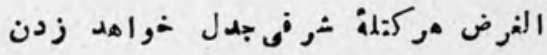



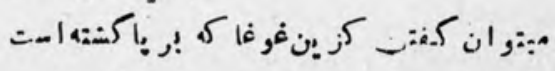

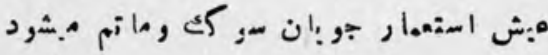




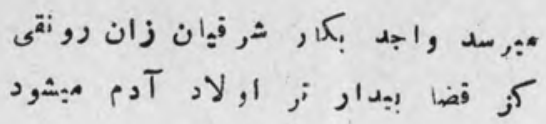

(1)

يجون هارا طال سركمثن خود به ن:ود

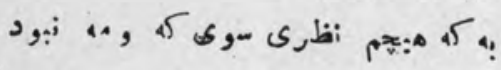

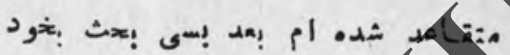

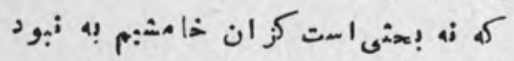

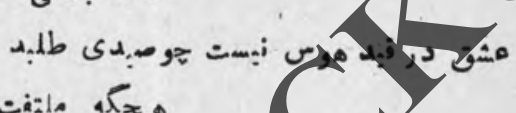

ه

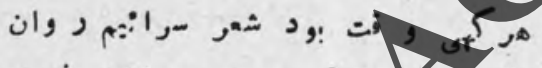

$$
\begin{aligned}
& \text { طن }
\end{aligned}
$$

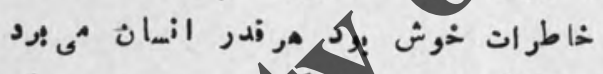

•

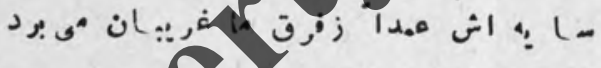

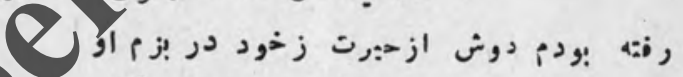

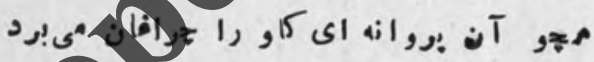

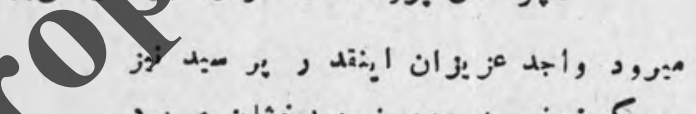

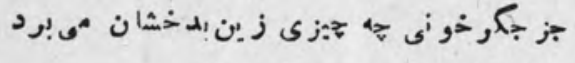

(2)

i

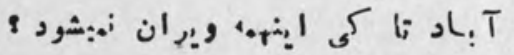

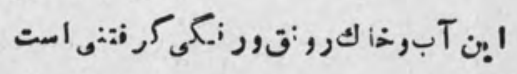

2, : 
از بأس بز ضرر ن:وان بإ نتى نثر

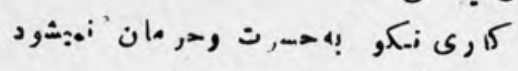

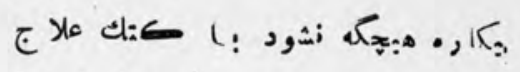

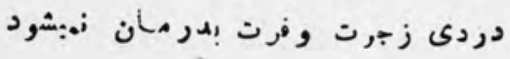

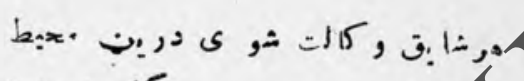

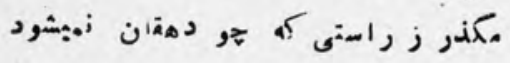

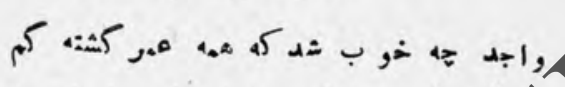

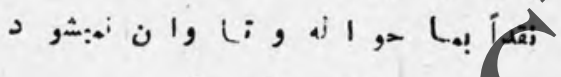

(1)

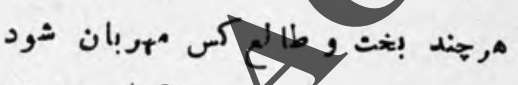

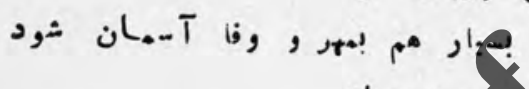

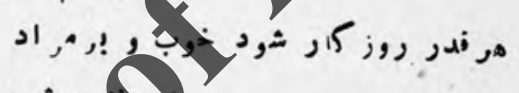

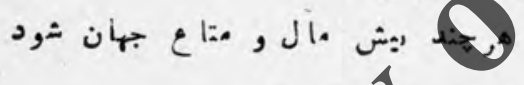

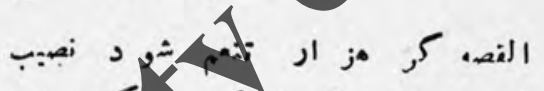

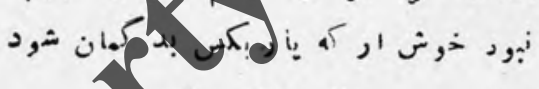

Q

- ,

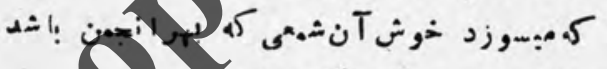

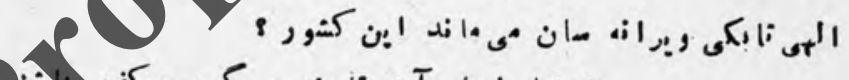

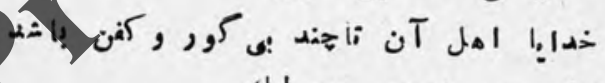
ز

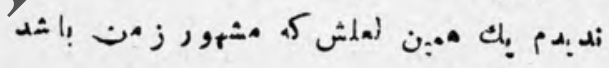

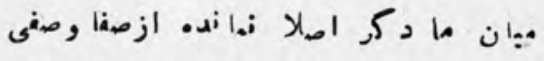

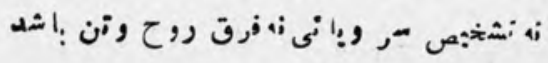

(1) 
كر ازيكلس:نان شدى iا بود ازدنيا مجب م:شد

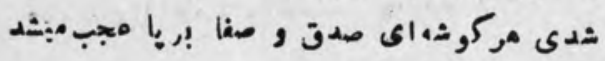

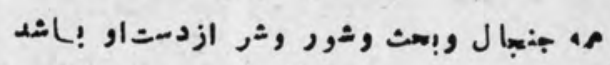

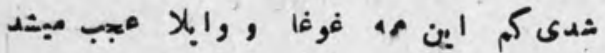

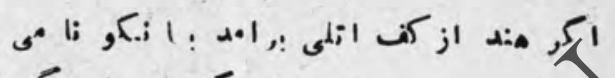

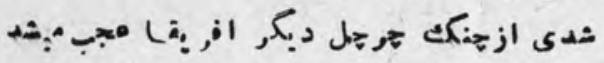

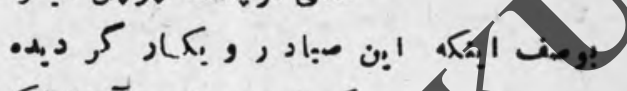

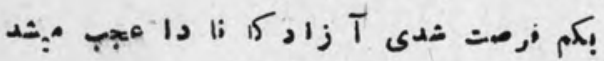

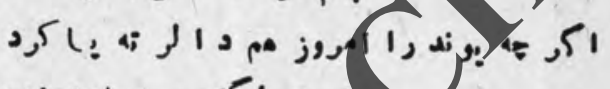

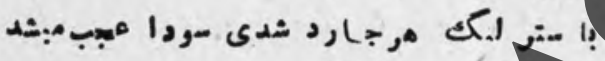

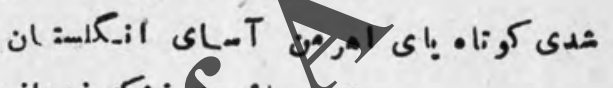

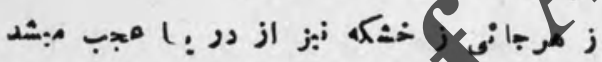

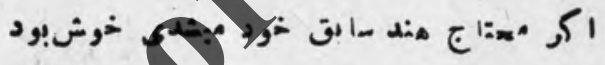

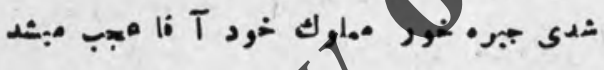

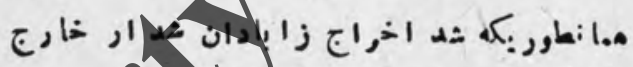

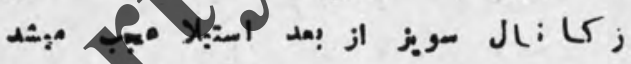

Q - -

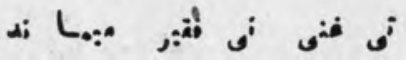

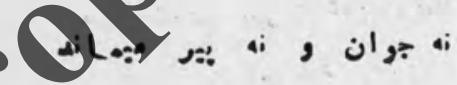

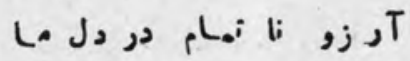

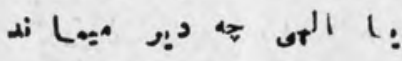

- 1 . ․ㅜㄴ

.

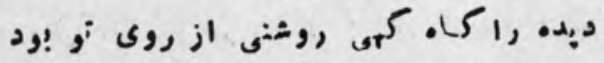

$\therefore$ (-) 


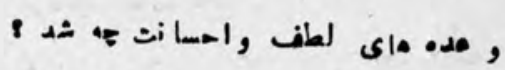

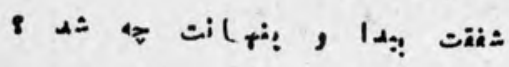

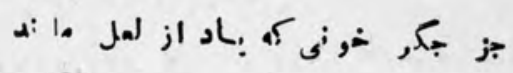

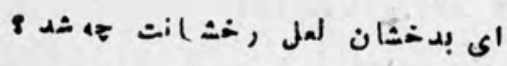

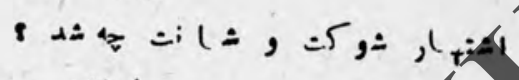

1املات

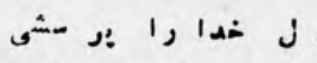

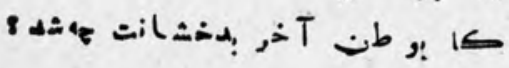

$$
\begin{aligned}
& \text { ثمثن } \\
& \text { إنهاز }
\end{aligned}
$$

(2)

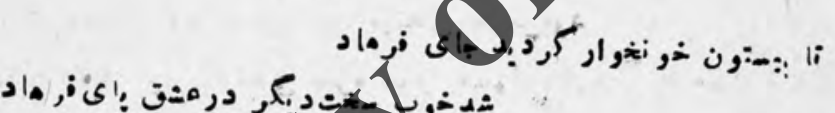

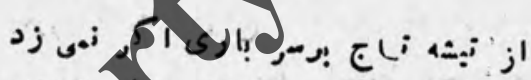

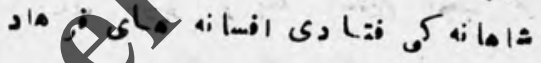

6 -

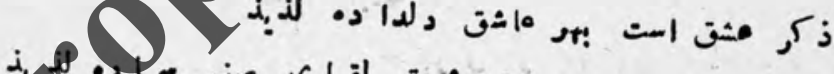

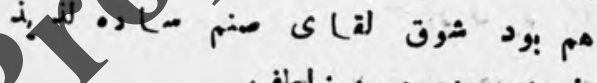

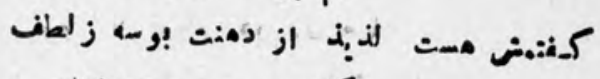

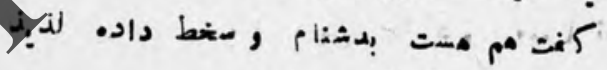

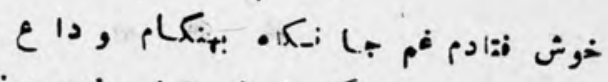

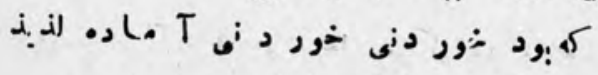

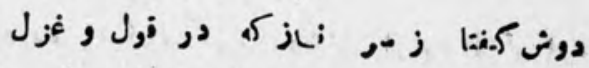

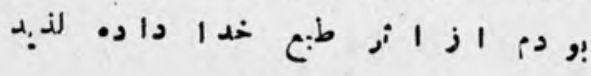




$$
=r r-
$$

كغ:هش طبع خدا داد كه :5غنيا بجو, اب

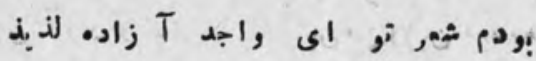

إ:جان بكא ام داد مه ع:ش داده ك:ر

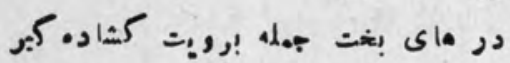

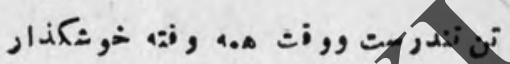

برخوان هميثه زهـت الروان نهاده كمر

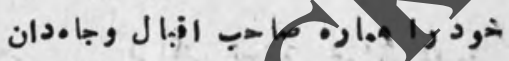

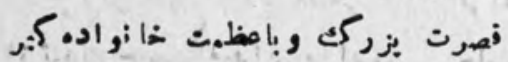

2,

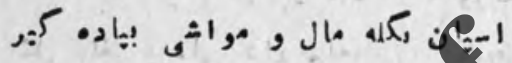

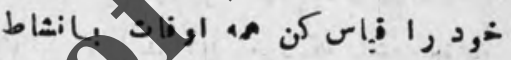

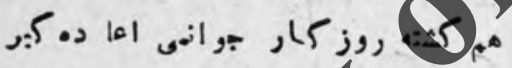

$$
\text { روز و, شيان به كما هروا:ت, كنش:ه درلن }
$$

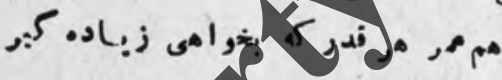

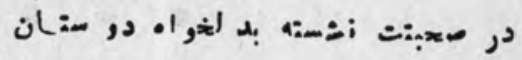

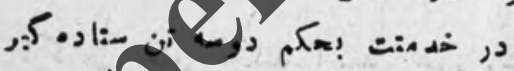

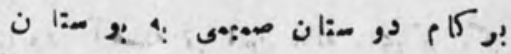

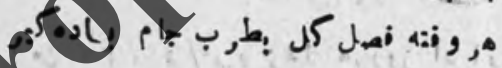

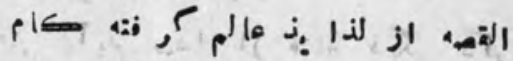

هر كر, هر صراد ؛

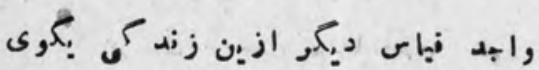

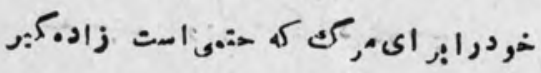




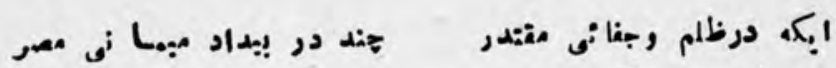

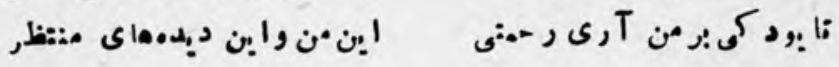

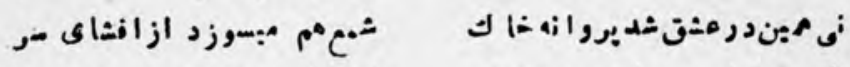

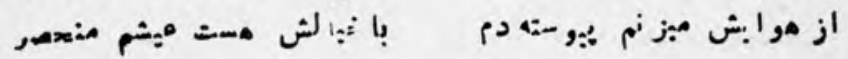

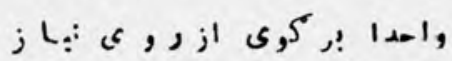

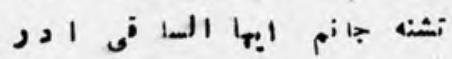

- 1

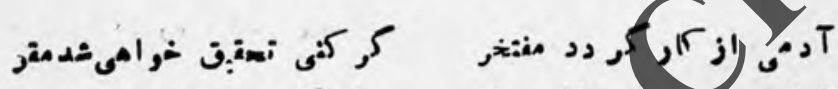

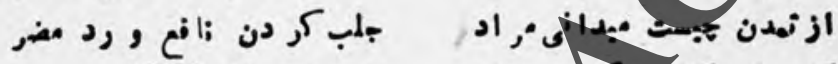

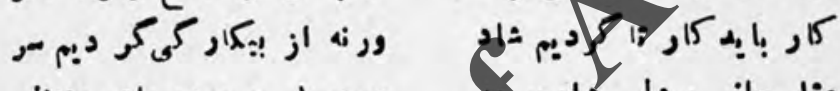

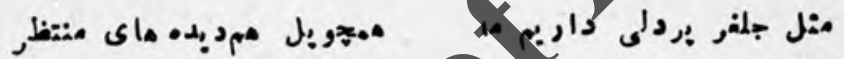

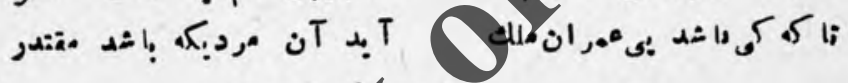

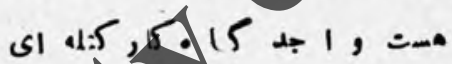

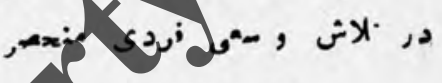

\section{Q - .}

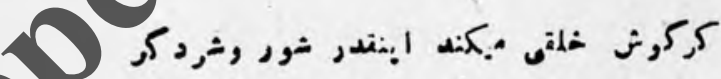

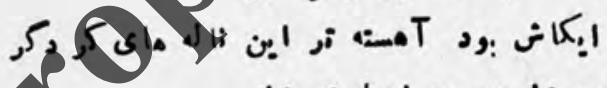

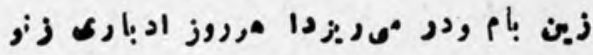

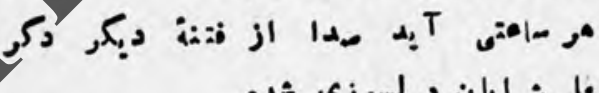

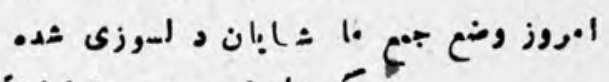

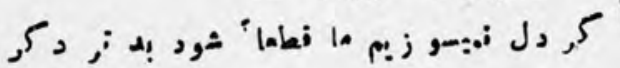

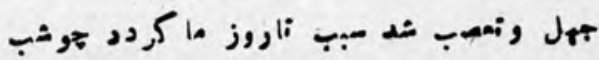

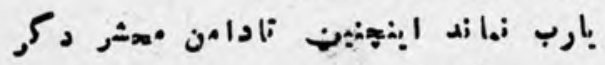

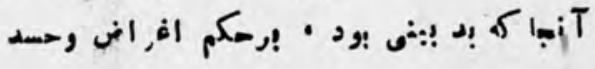




$$
=r o=
$$

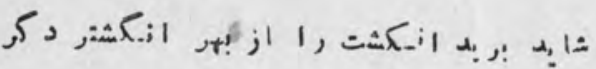

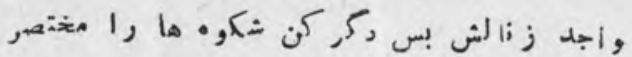

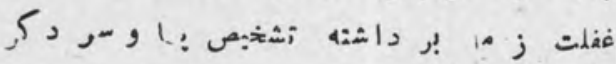

(2)

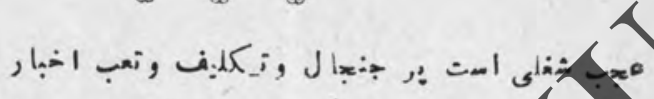

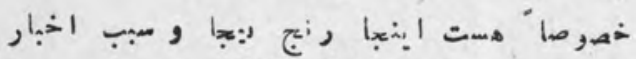

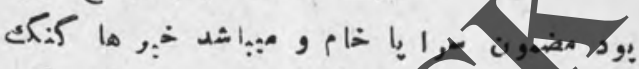

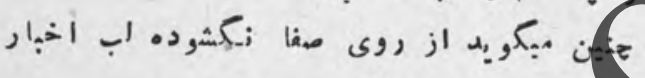

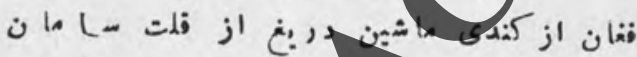
!

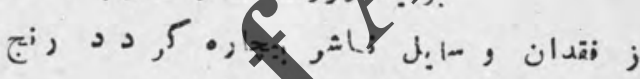

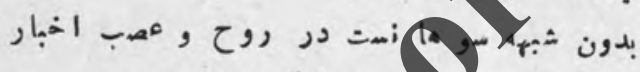

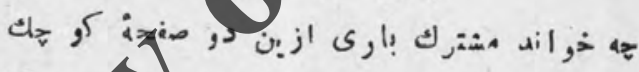

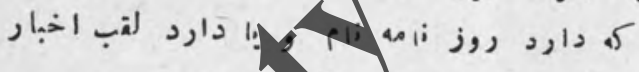

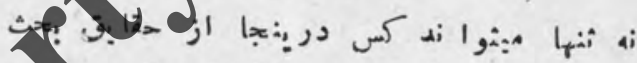

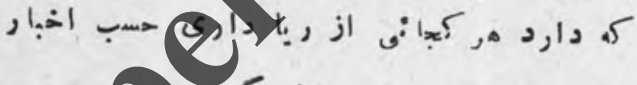

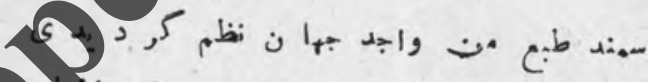

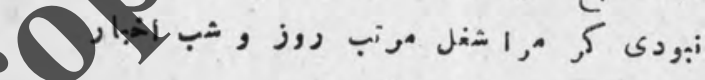

$$
\text { (1) }
$$

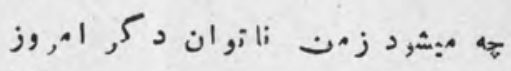

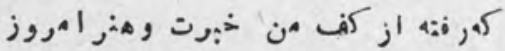

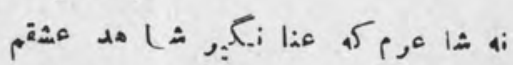

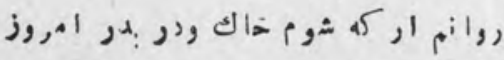

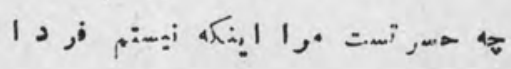




$$
=r y=
$$

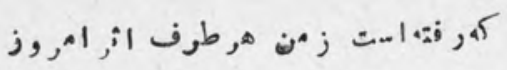

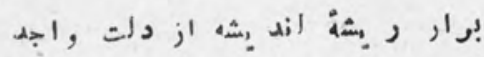

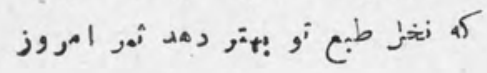

(6)

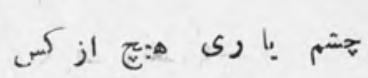

خد ا أند م بود فرياد رس بس

$$
\text { जा } \int_{x \neq \infty}
$$

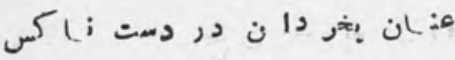

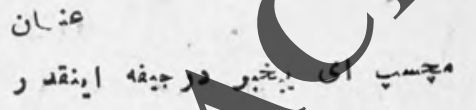

مردار مادت مAجو كركس

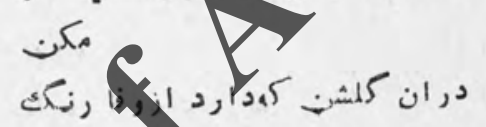

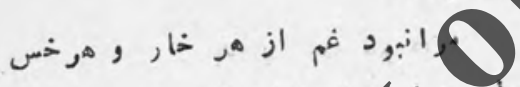

$$
\begin{aligned}
& \text { هis } \\
& \text { r, ك } \\
& \text { 人) }
\end{aligned}
$$

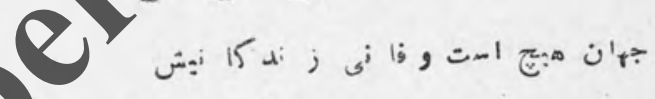

إنها

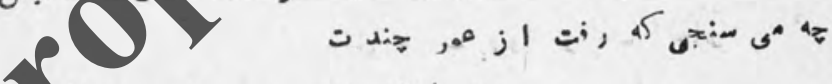

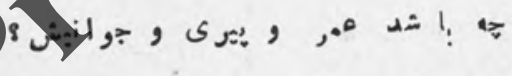

(6)

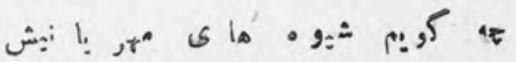

ش: ا

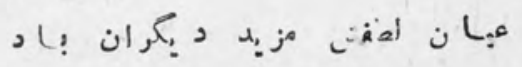

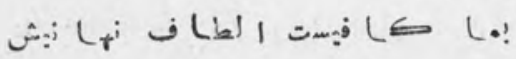




$$
-r V=
$$

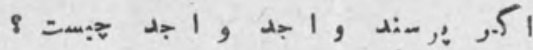

$$
\begin{aligned}
& \text { iي } 12 \text { a: }
\end{aligned}
$$

\section{(2)}

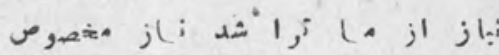

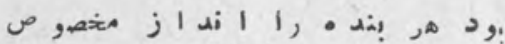

$$
\text { !' }
$$

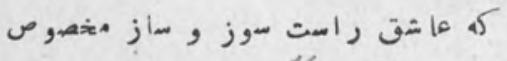
صدا: كه شيدا را بو ز

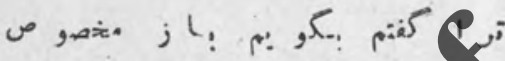

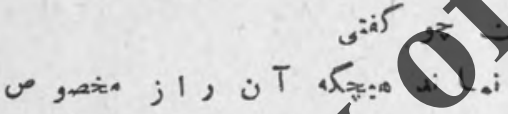

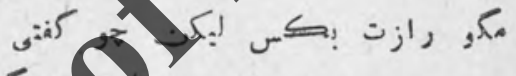

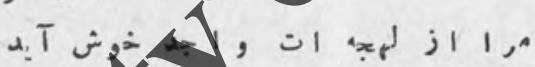
ك 017 : ض

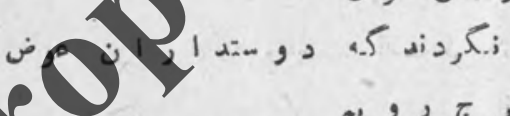

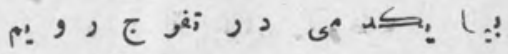

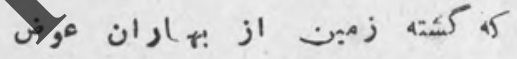

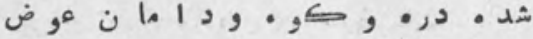

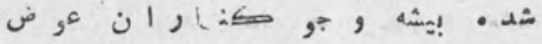

(3) 9

L. $c^{i, 2, ~}$ ض, 


$$
\begin{aligned}
& =r \wedge=
\end{aligned}
$$

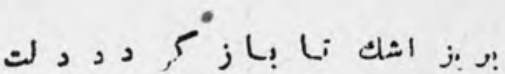

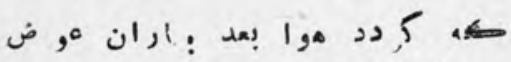

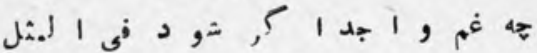

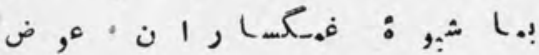

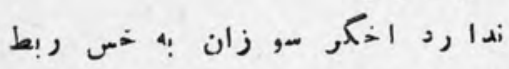

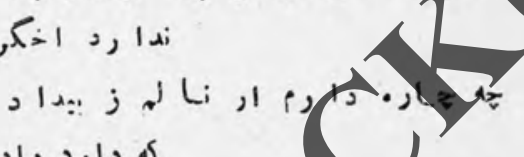

نه

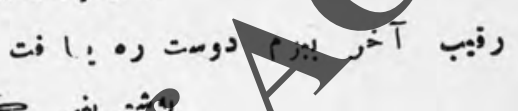

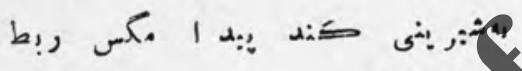

i

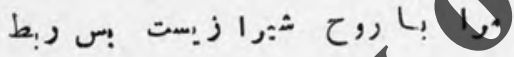

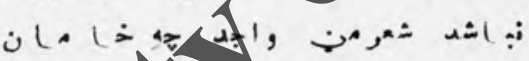

$$
\begin{aligned}
& \text { b: }
\end{aligned}
$$

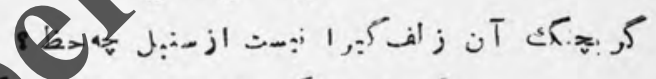

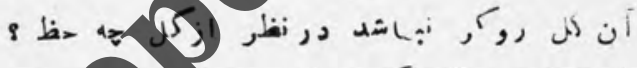

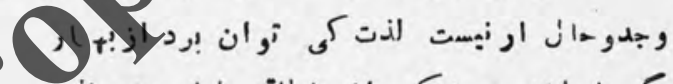

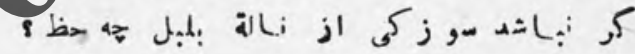

(1) (3)

$$
\text { : }
$$

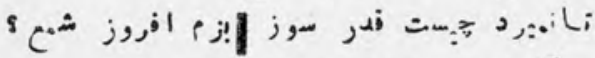

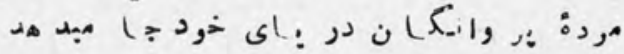

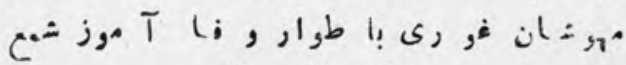

(6) 8영 


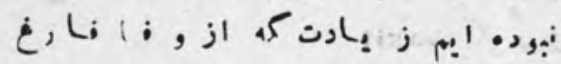

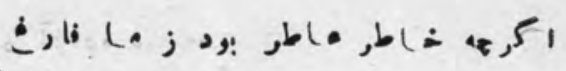

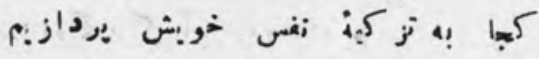

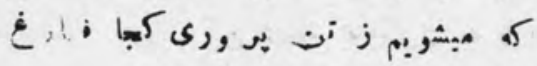

-

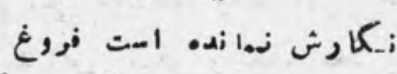

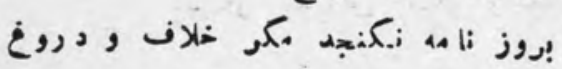

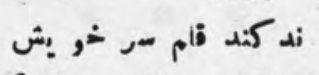

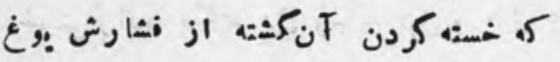

$$
\text { : : }
$$

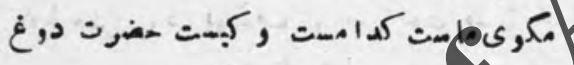

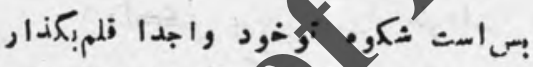

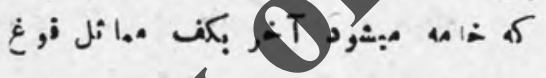

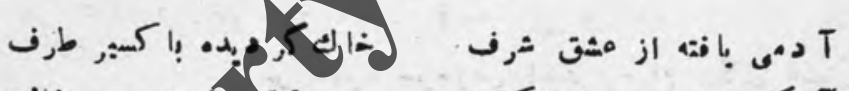

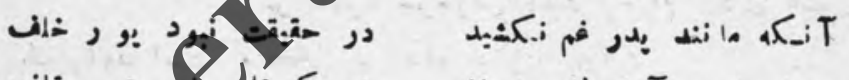

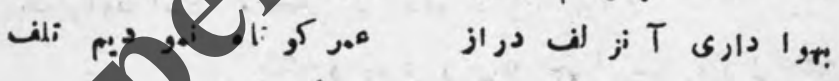

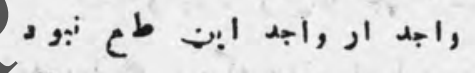

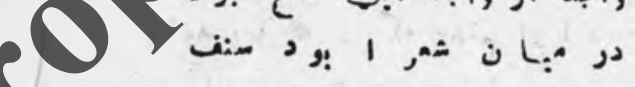

\section{- 1}

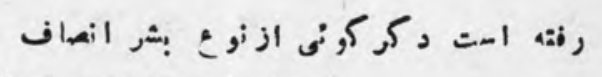

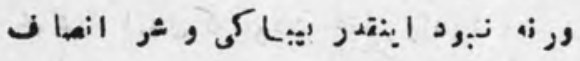

$$
\begin{aligned}
& \text { - } 1
\end{aligned}
$$

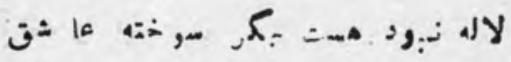

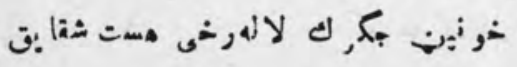




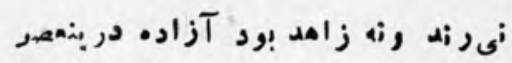

ازتاد. :

$$
\text { جز }
$$

آن

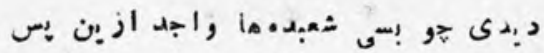

ز. لإ:

(क)

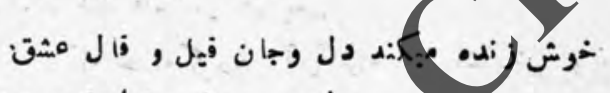

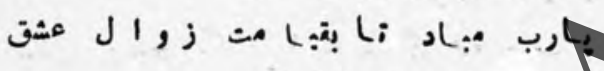

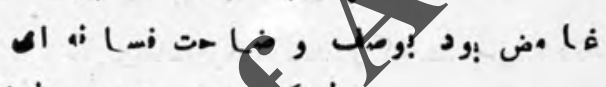

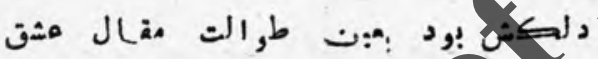

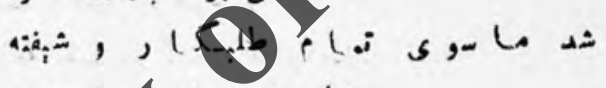

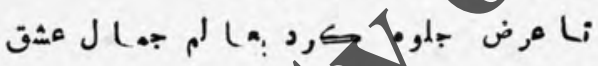

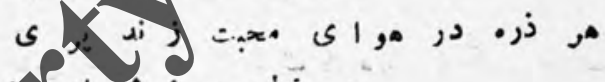

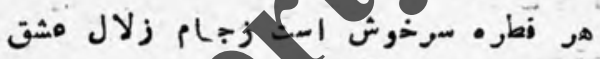

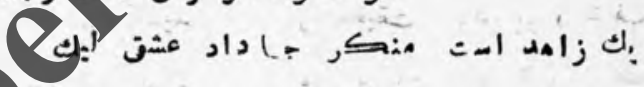

Aلف

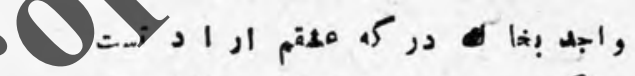

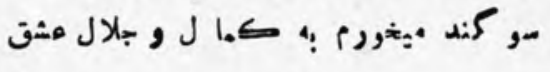

$$
\text { 인 }
$$

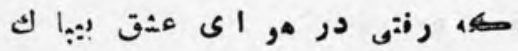

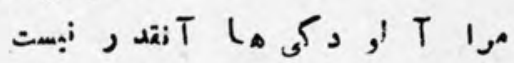

el 1 : 
$-\mu \nu=$

مراز إين عشق ابن التظا ر است

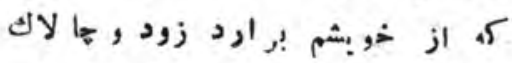

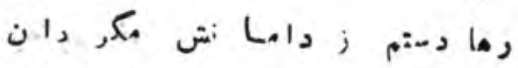

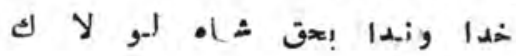

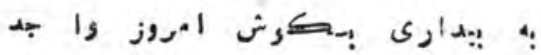

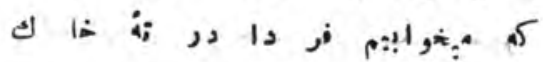

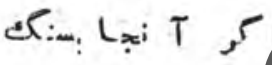

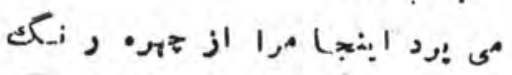

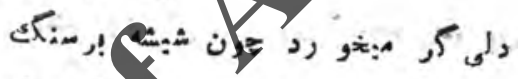

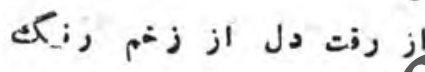

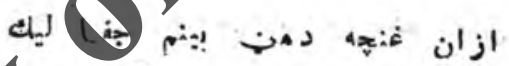

ائم,

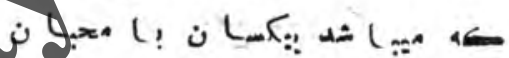

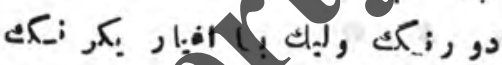

كند Ti

!و

خسته شد خاطر لذ بجث فا ل و زبل

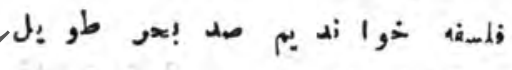

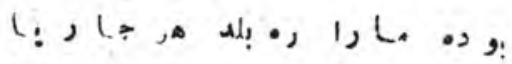

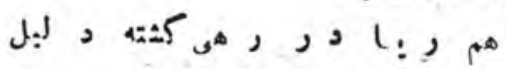

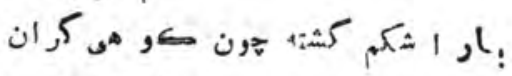

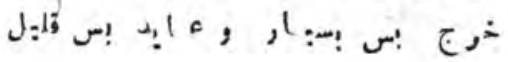




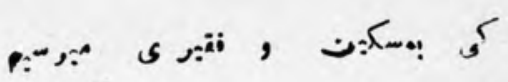

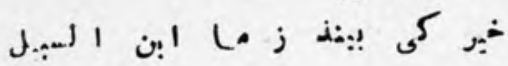

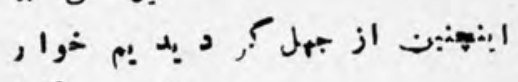

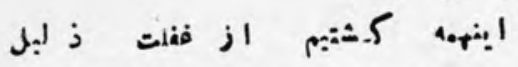

ت:

-

-

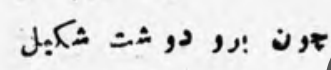

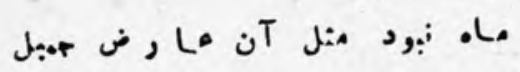

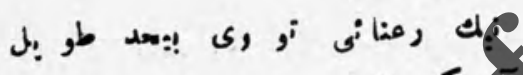

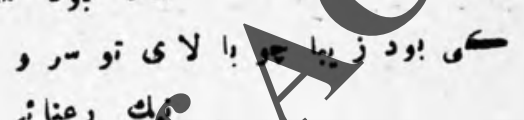

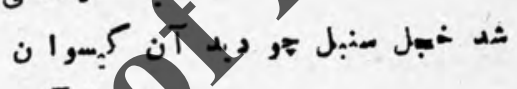

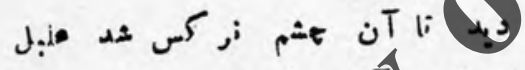

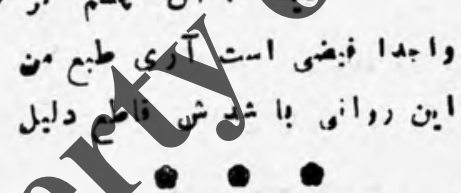

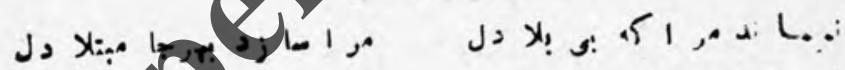

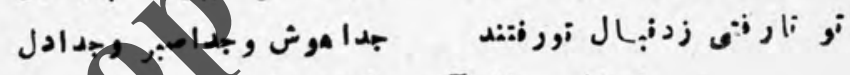

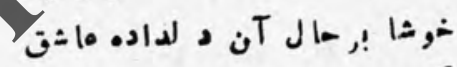

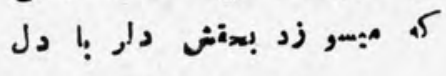

- 10

$$
\text { " }
$$

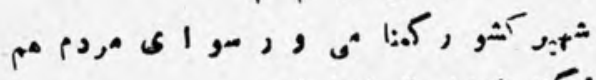

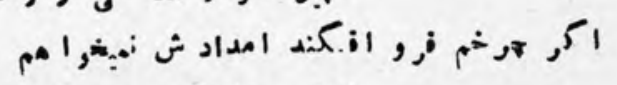

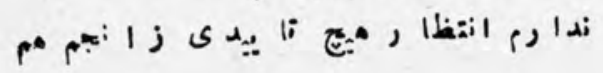




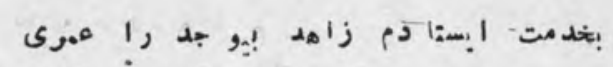

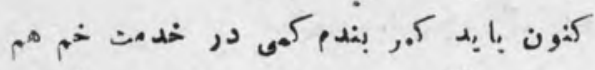

$$
\text { ز }
$$

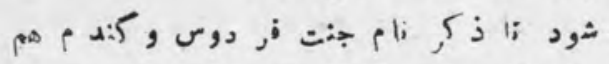

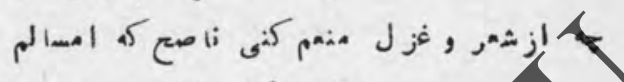

ز ز

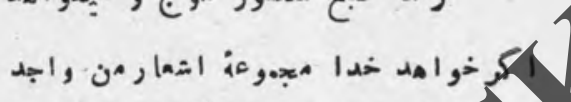

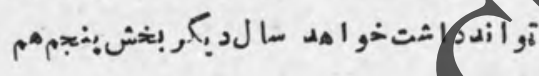

(2) 웅

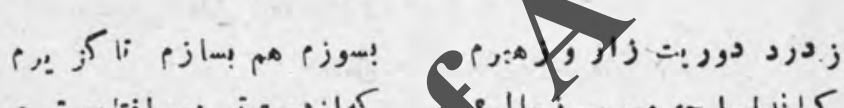

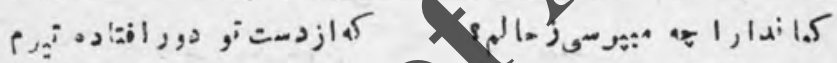

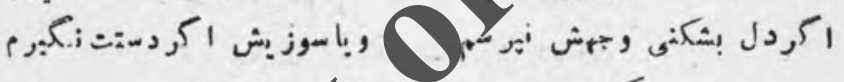

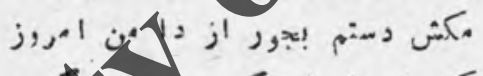

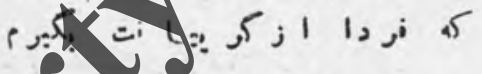
(1)

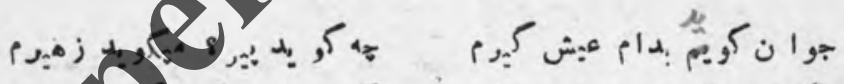
.

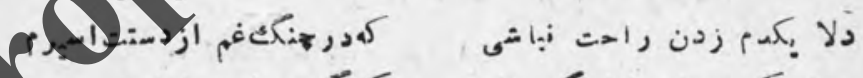
ind

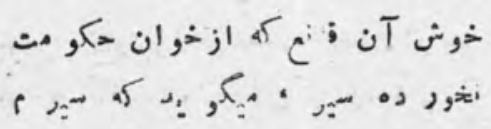

(2)

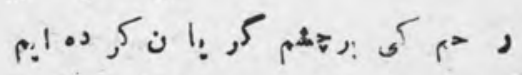

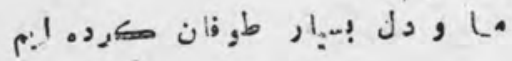




$$
-\mu \varepsilon=
$$

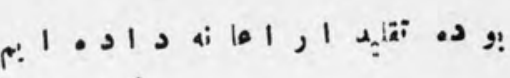

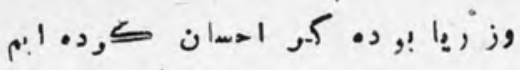

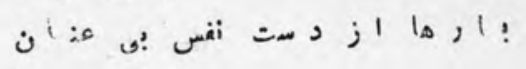

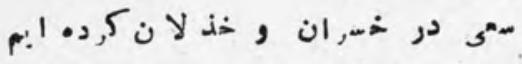

$$
\begin{aligned}
& \text { •. }
\end{aligned}
$$

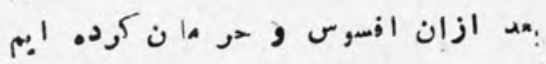

$$
\begin{aligned}
& \text { (3) क्ष }
\end{aligned}
$$

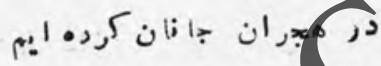

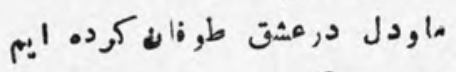

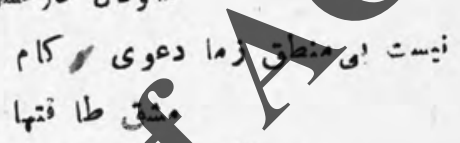

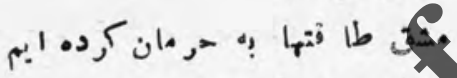

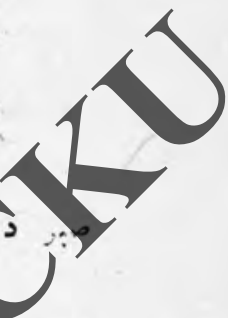

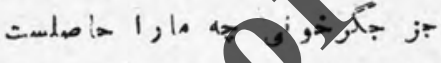

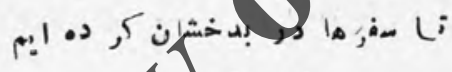

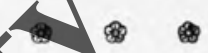

48

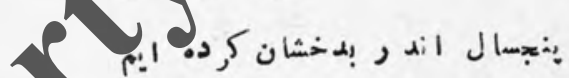

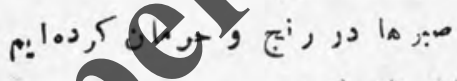

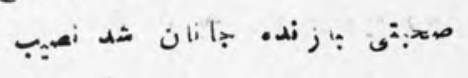

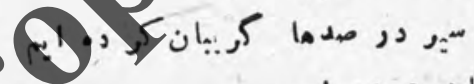

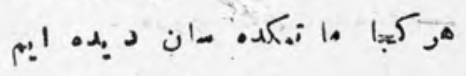

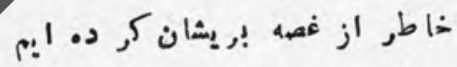

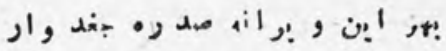

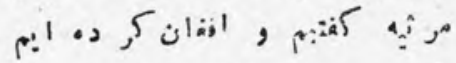

중

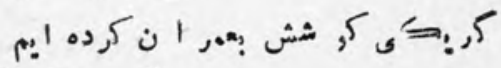

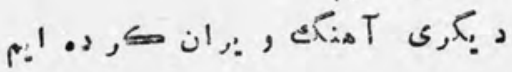




$$
\begin{aligned}
& -\infty w_{0}= \\
& \text { د }
\end{aligned}
$$

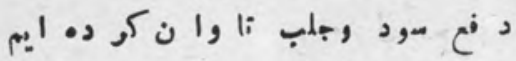

$$
\text { L. }
$$

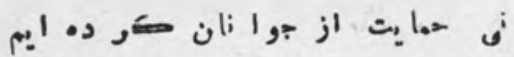

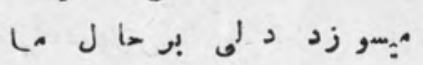

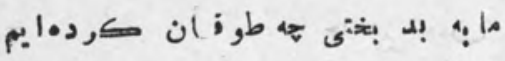

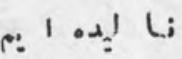

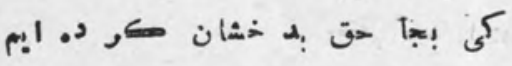

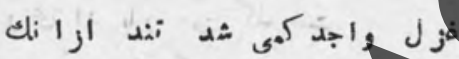
ا أسـان

(1)

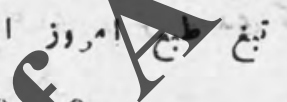

is

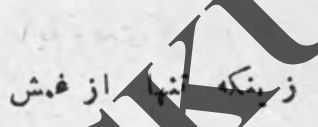

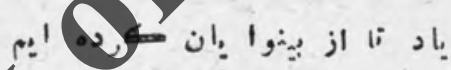

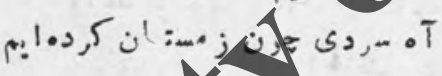

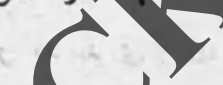

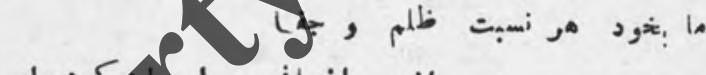

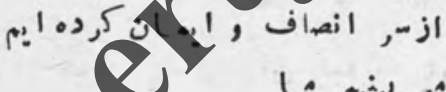

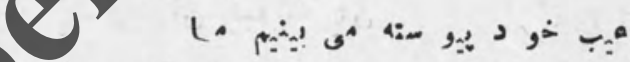

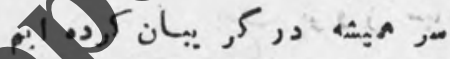

$$
\text { كر i, } 1 \text { : } 1 \text { : } 1 \text { : }
$$

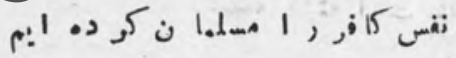

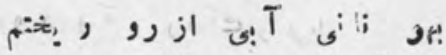

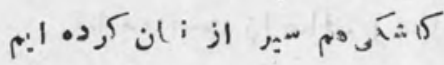

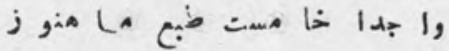

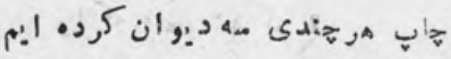

(2) 


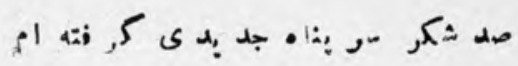

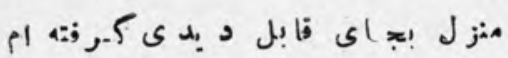

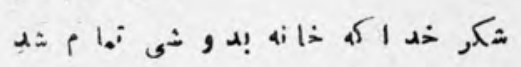

.

$$
\text { ن }
$$

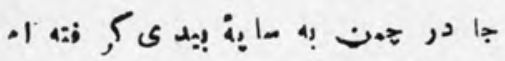

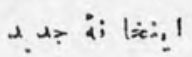

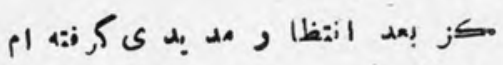

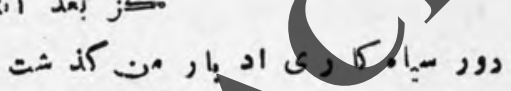

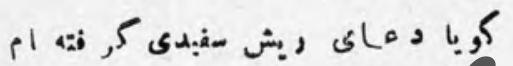

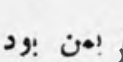

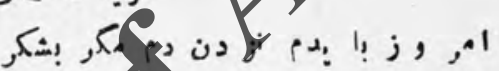

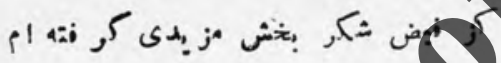

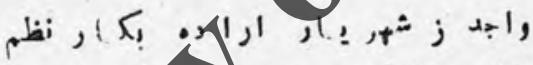

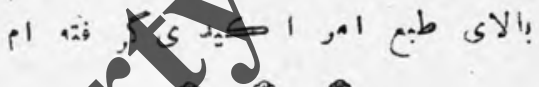
(1)

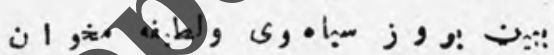

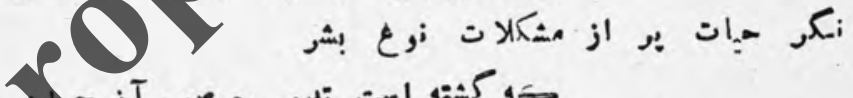

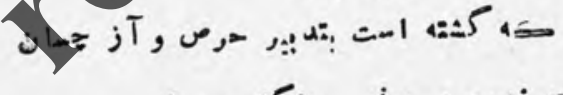

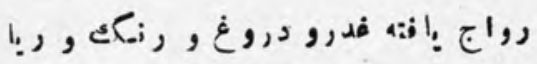

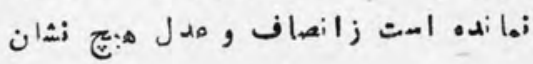

- अ

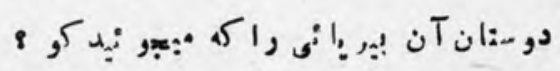

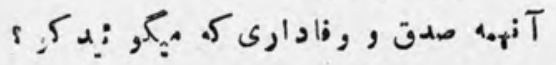




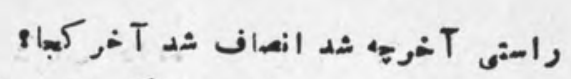

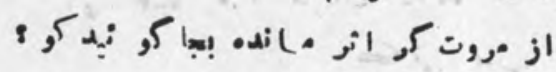

$$
\text { - . }
$$

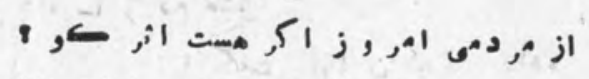

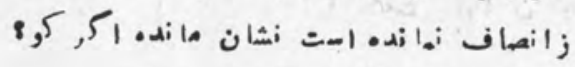

$$
\text { بهث is }
$$

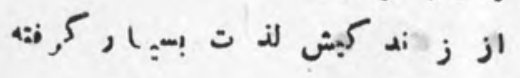

ش

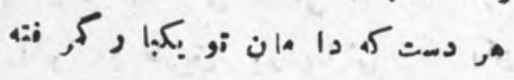

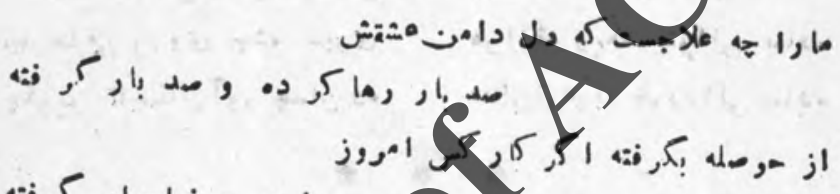

:

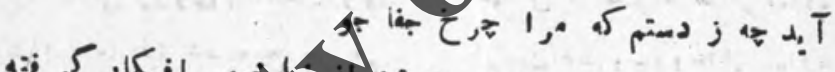

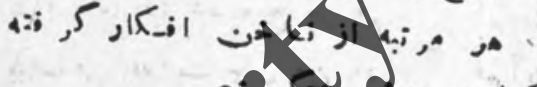

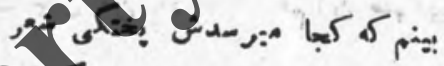

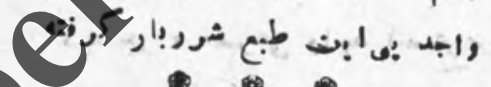

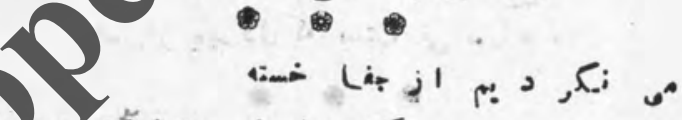

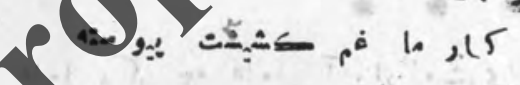

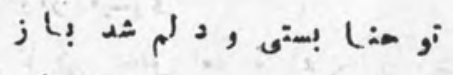

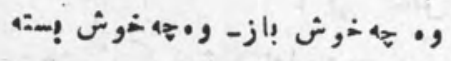

क

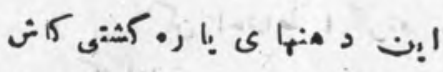

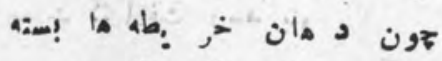

(2) 


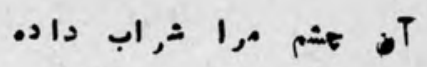

ا

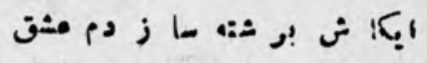

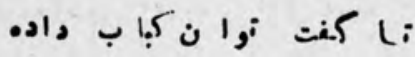

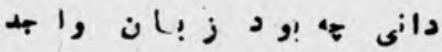

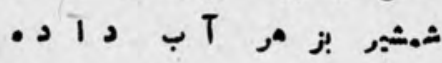

-

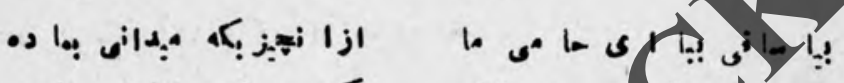

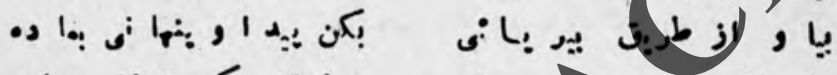

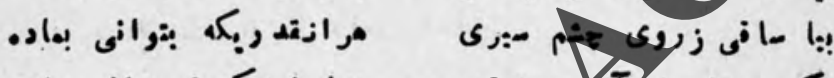

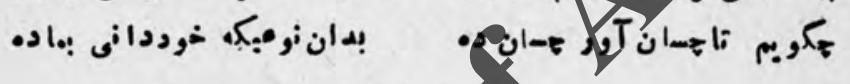

-

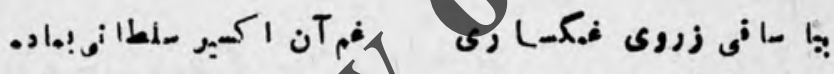

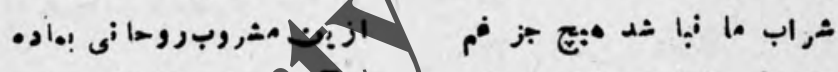

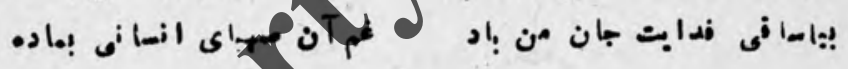

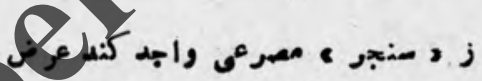

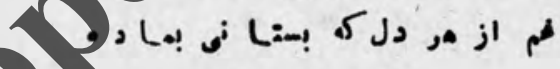

e 1

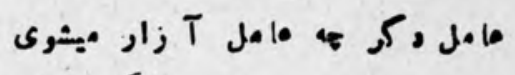

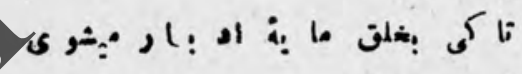

$$
\text { اه, وز }
$$

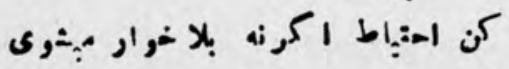

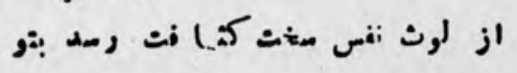

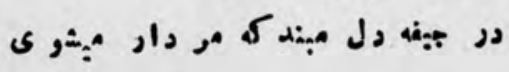




$$
\begin{aligned}
& =r a= \\
& \text { دوزى رسد كא عثم بـ:رت كثا بد ثت }
\end{aligned}
$$

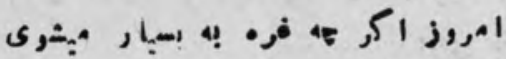

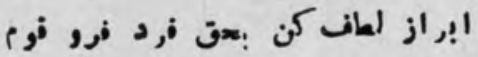

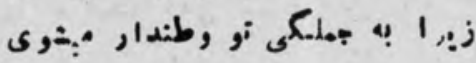

- -

$$
\text { از بك أكهى راه دل ها زده إى }
$$

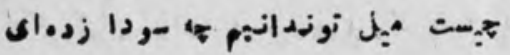

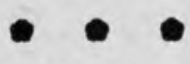

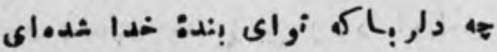

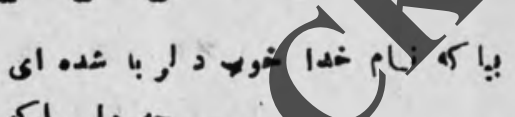

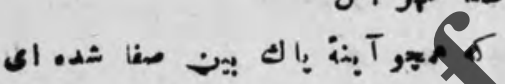

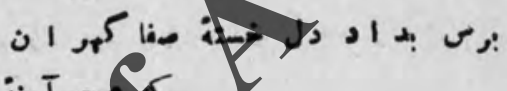

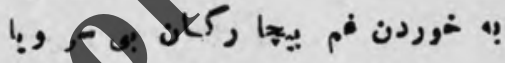

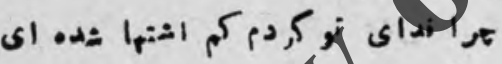

$$
\begin{aligned}
& \text { Jl- }
\end{aligned}
$$

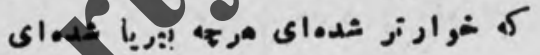

$Q$

1

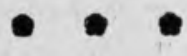

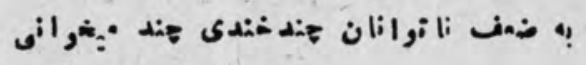

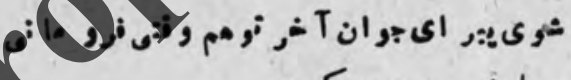

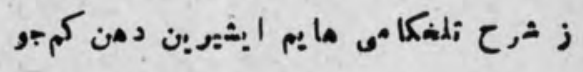

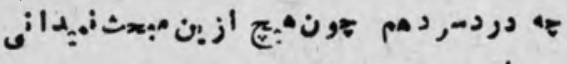

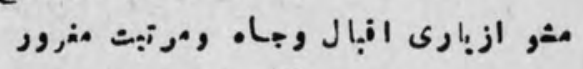

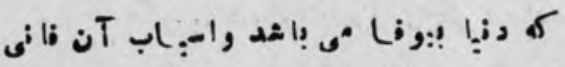

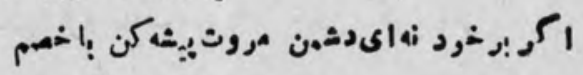

رفا ازدو هـت همكن قدر هر فدر بكه ب:ترانى 
نب! يد اء:بار , وزت وبا داد و زور و زر

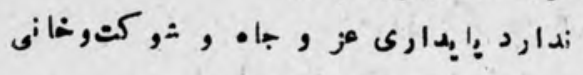

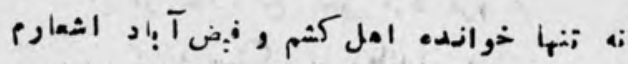

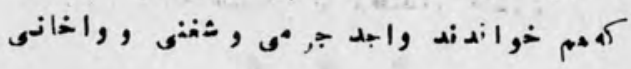

-

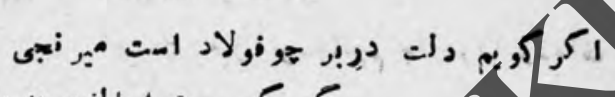

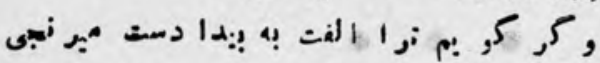

- 1

دل وم:ر,

لן

-

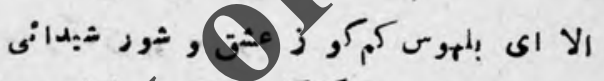

كه 15 ,

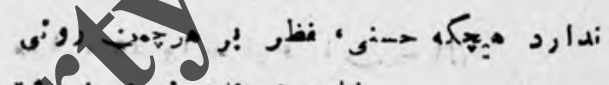

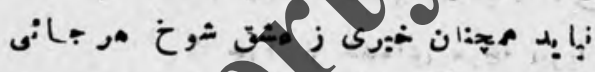

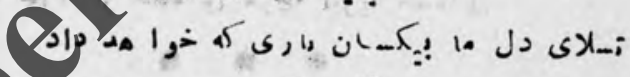

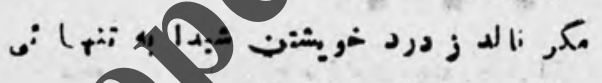

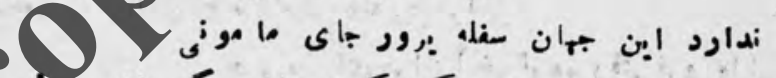

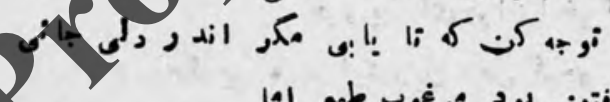

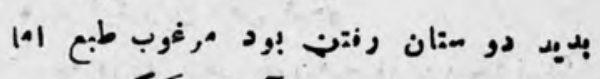

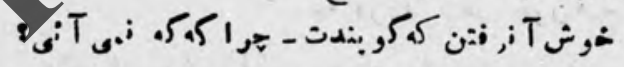

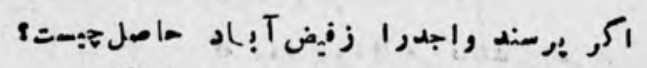

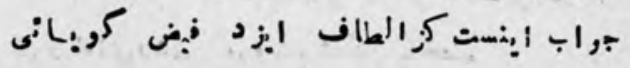

- (1) 


\section{f.al}

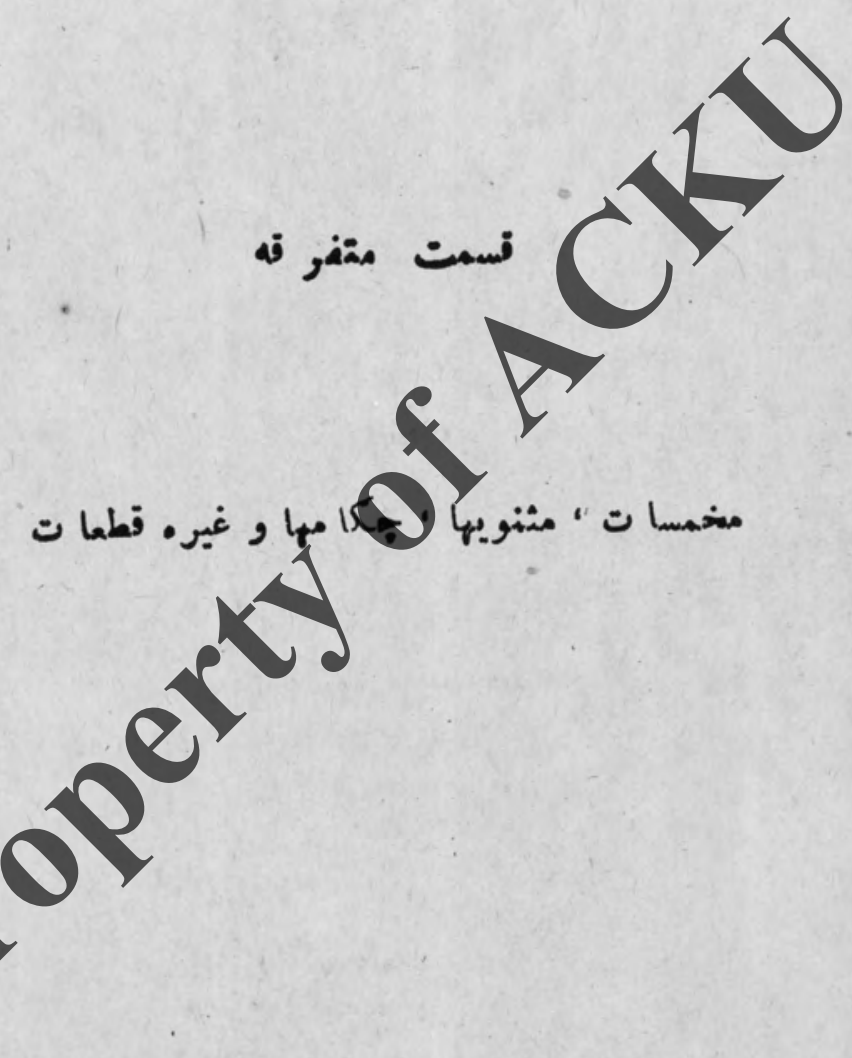




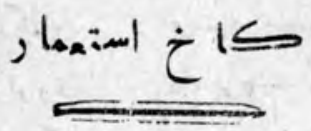

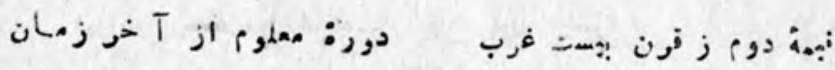

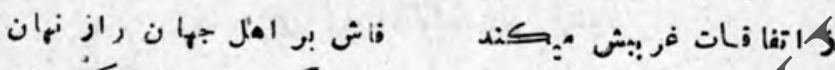

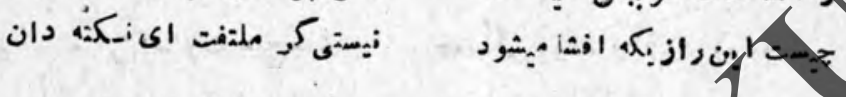

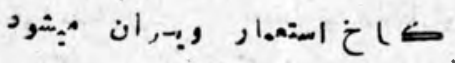

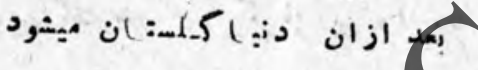

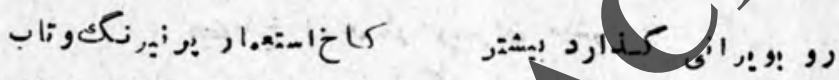

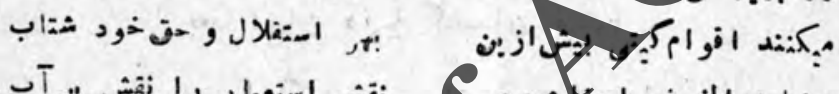

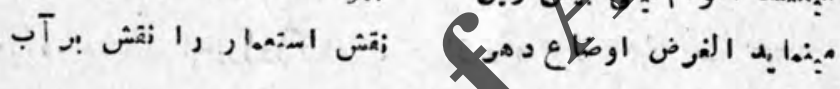

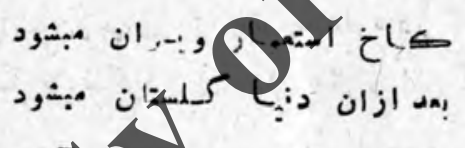

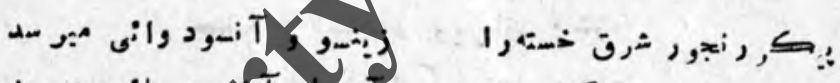

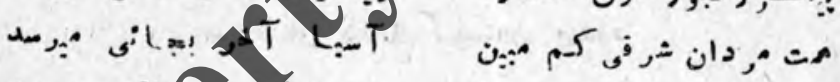

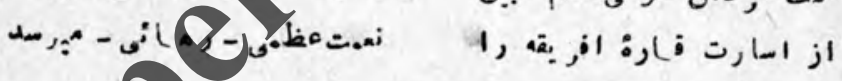

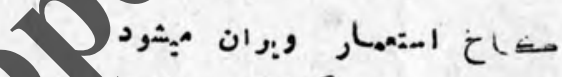

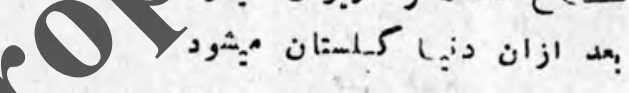

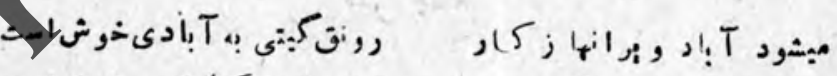

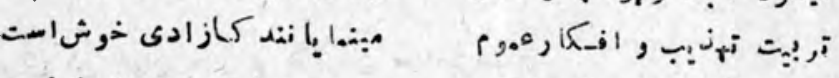

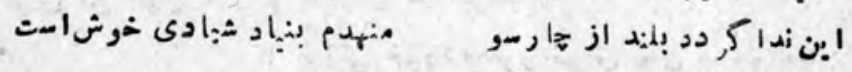

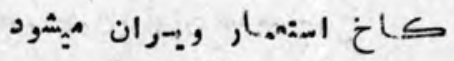

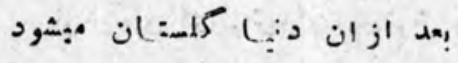




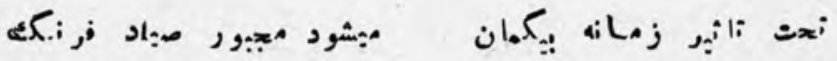

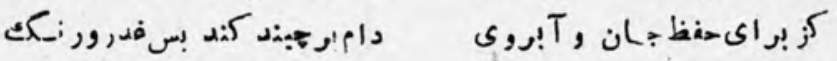

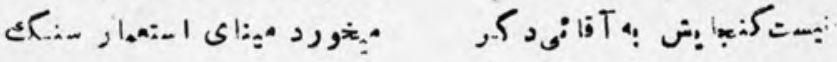

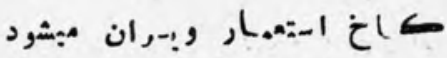

$$
\begin{aligned}
& \text { : }
\end{aligned}
$$

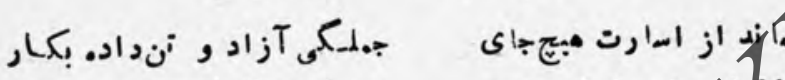

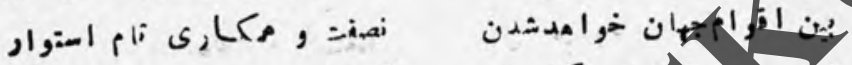

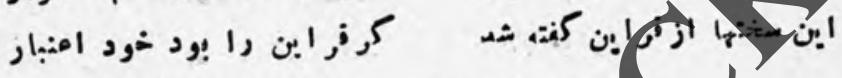

$$
\begin{aligned}
& \text { كان }
\end{aligned}
$$

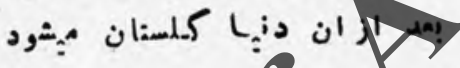

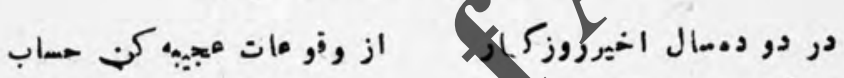

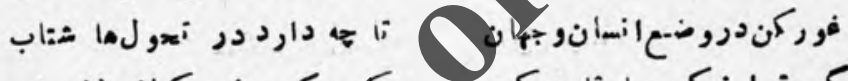

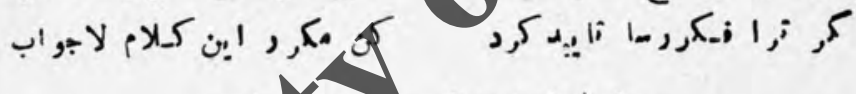
每

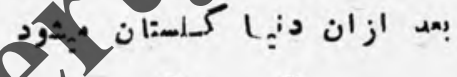

-

$$
\begin{aligned}
& \text { - } \\
& C^{-3} \cdot
\end{aligned}
$$

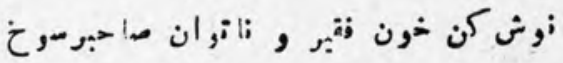

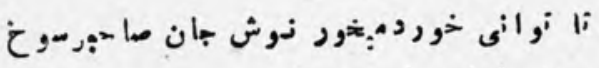

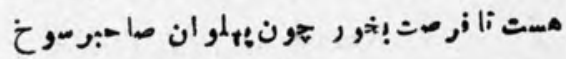

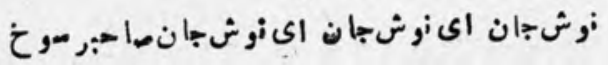




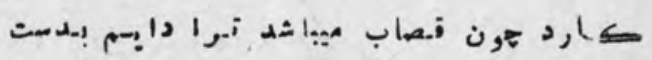

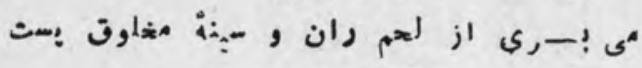

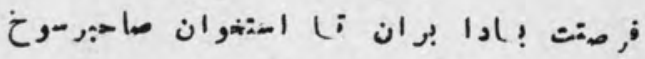

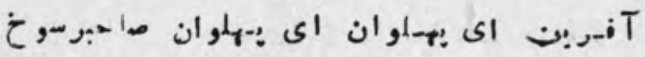

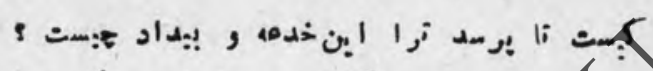

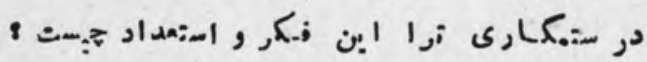

i

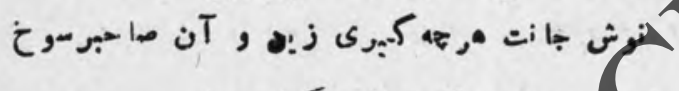

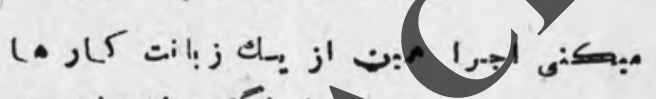

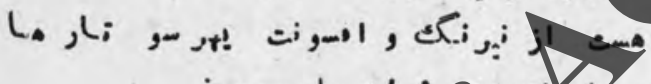

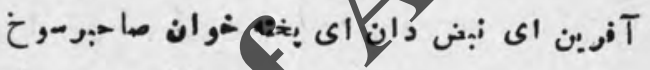

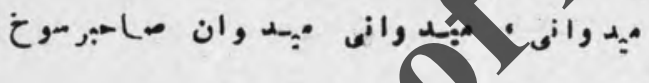

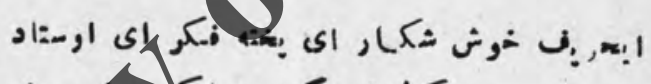

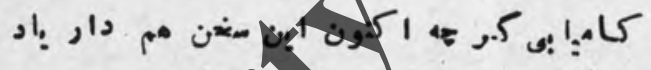

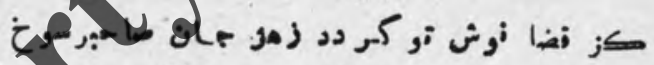

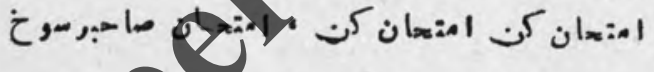

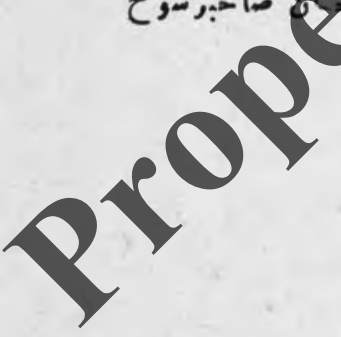

둥

.

뭉

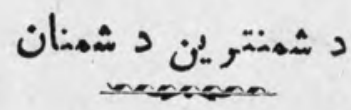

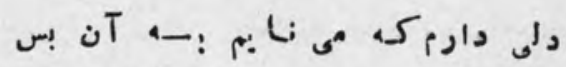

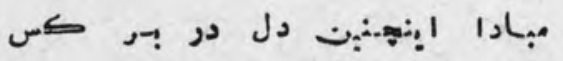

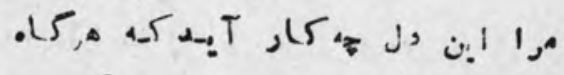

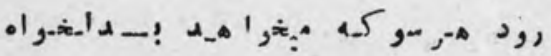




$$
=\varepsilon \varepsilon-
$$

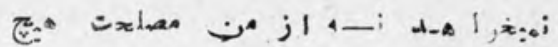

E:

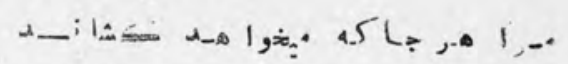

-i أ-

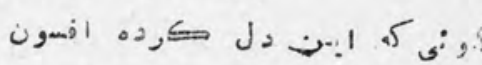

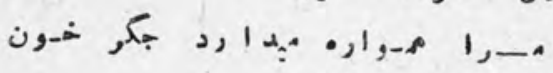

$$
\text { bI, } 1.5 \text {. }
$$

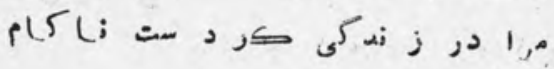

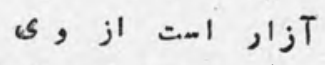

•

$$
\begin{aligned}
& \text {. } \\
& \text { A 1,... }
\end{aligned}
$$

앙

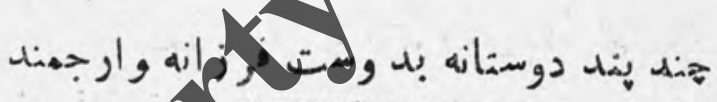

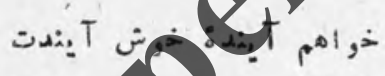

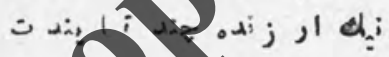
خون

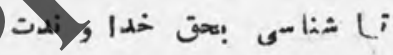

\% أش

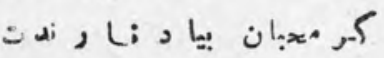

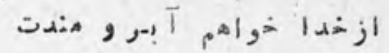
ه

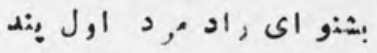

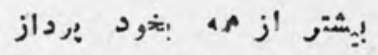

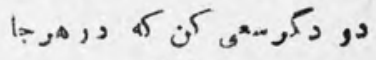

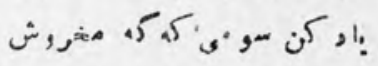

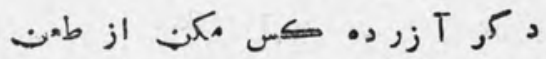

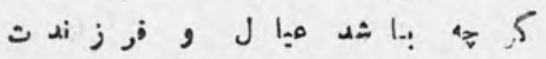

(2) (2) 


\section{$5 \omega$}

\section{هن}

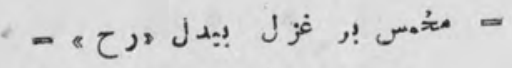

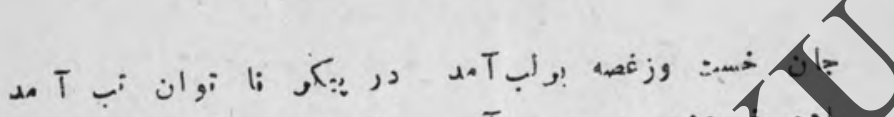

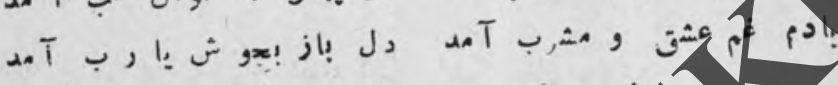

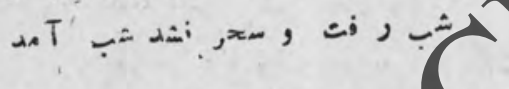

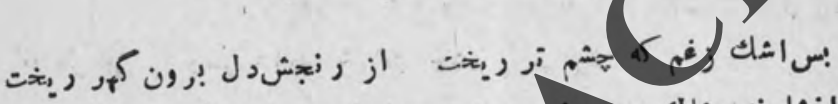

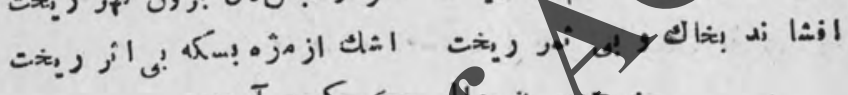

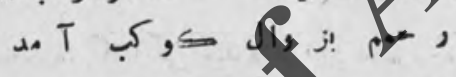

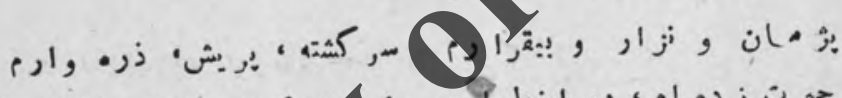

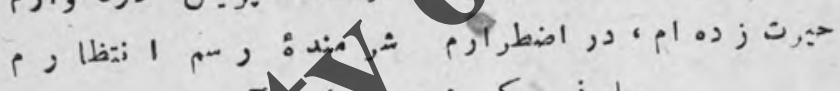
A. Th

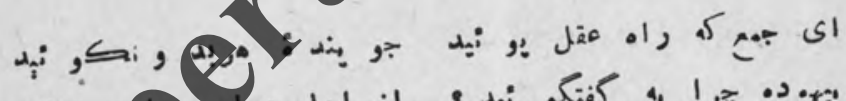
:

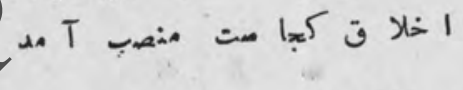
0

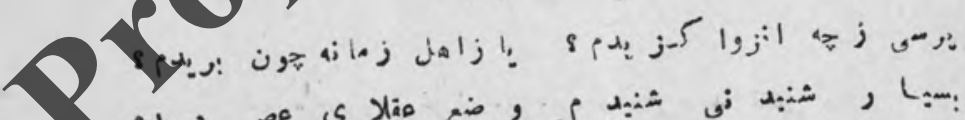

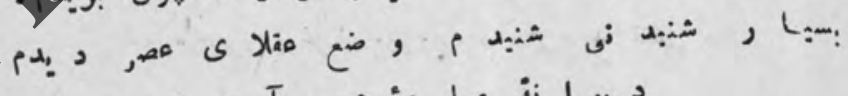

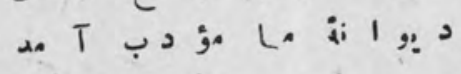

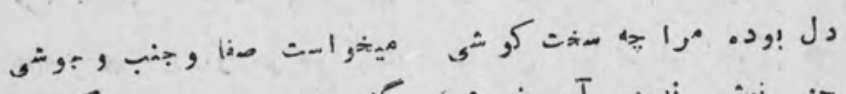

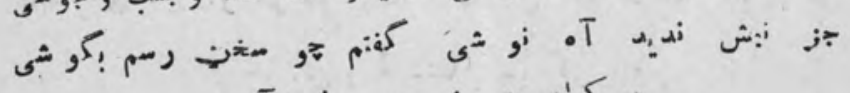

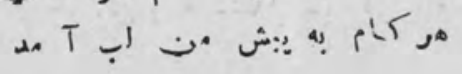




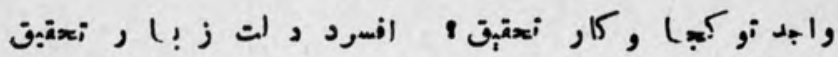

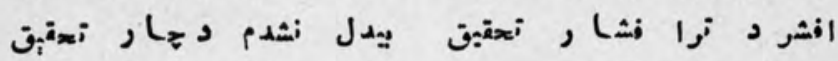

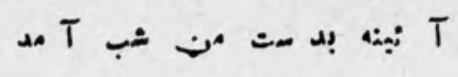

*

-

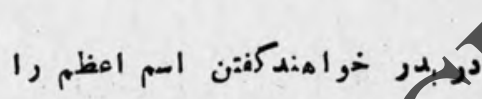

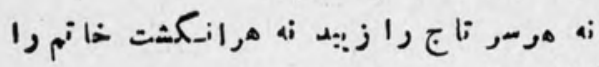

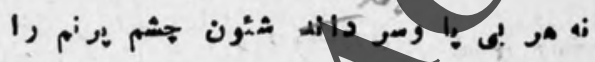

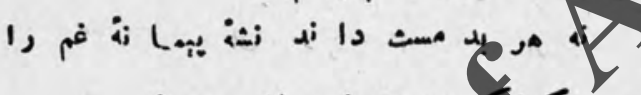

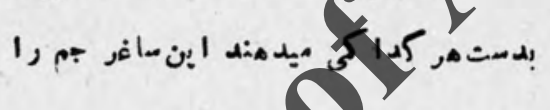

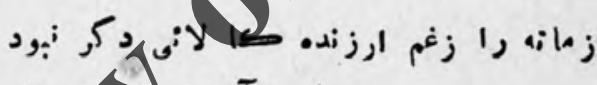

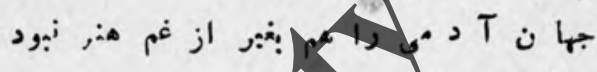

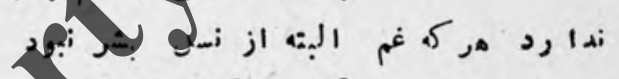

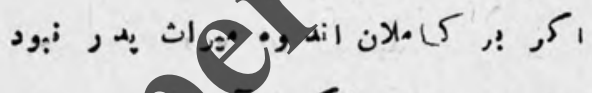

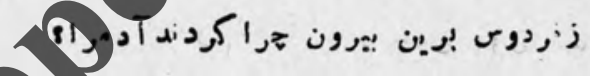
$\rho$

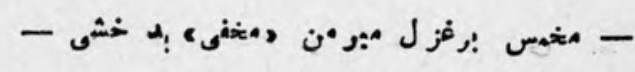

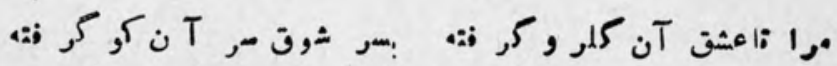

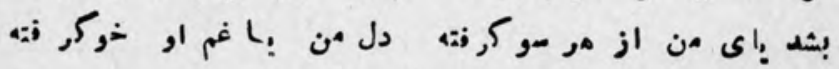

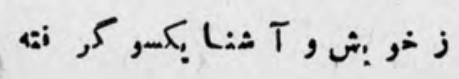




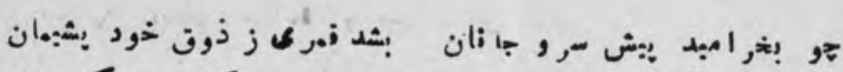

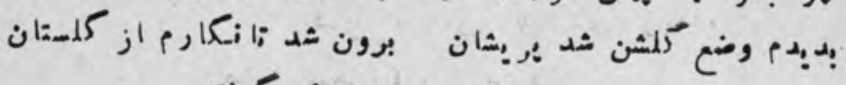

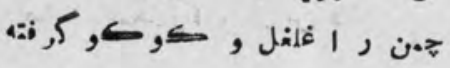

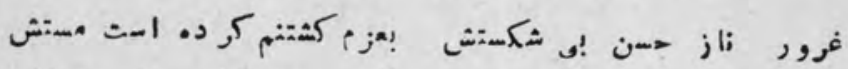

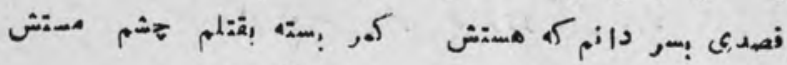

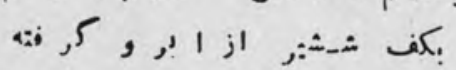

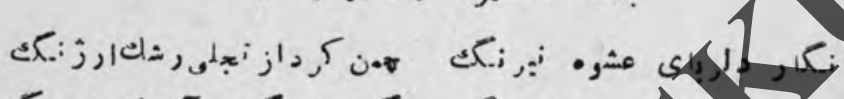

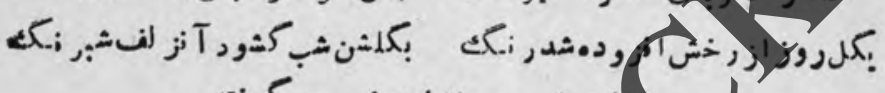

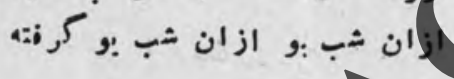

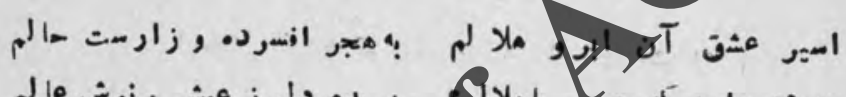

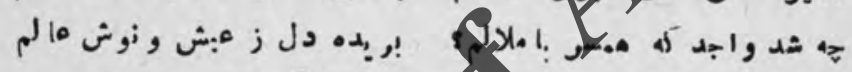

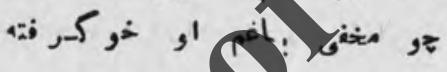

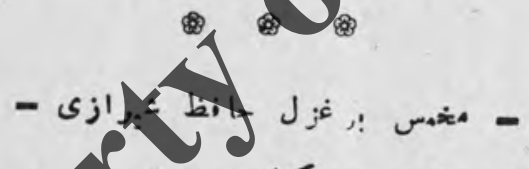

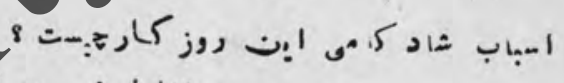

$8=0$ a

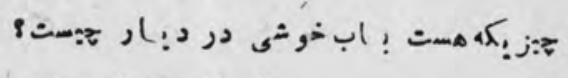

خ

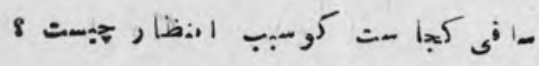

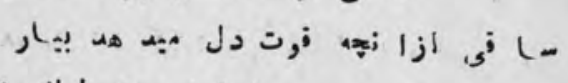

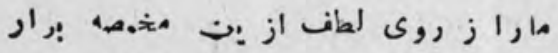

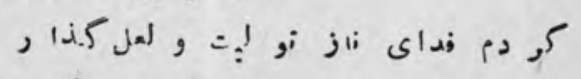

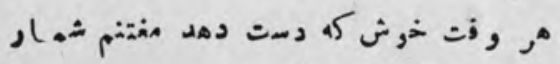

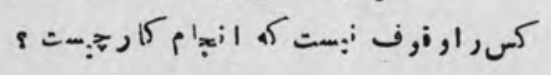




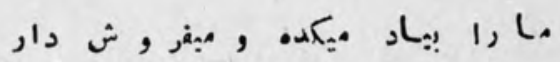

دري اد هثق وبنغردى ورو وجد و جوش دار

$$
\text { عر ض:ثت هنلصا نه iكا را , ركو ش دار, }
$$

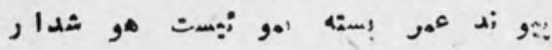

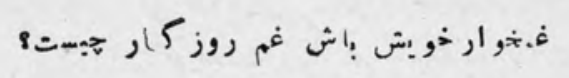

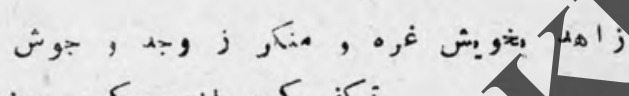

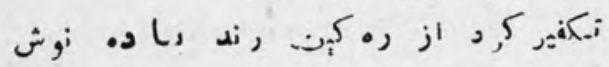

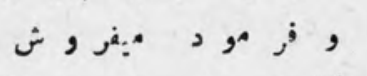

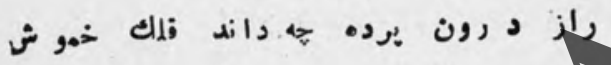

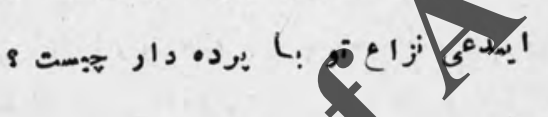

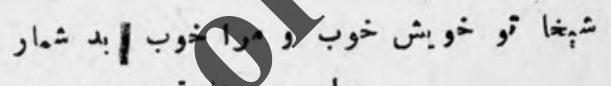

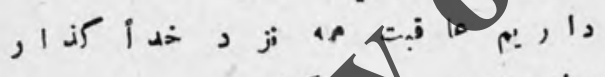

, IS

\&

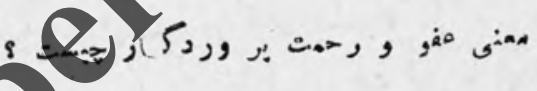

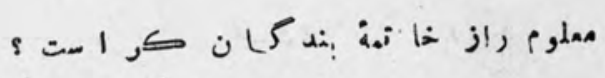

,

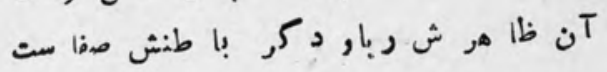

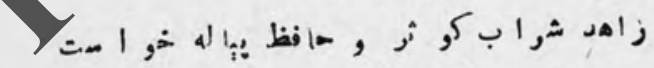

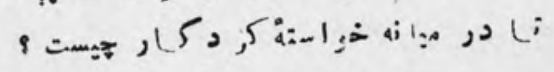




\section{9

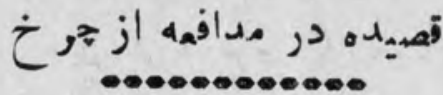

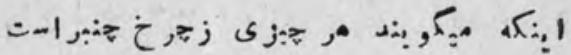

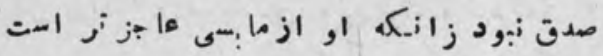

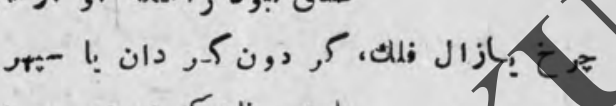

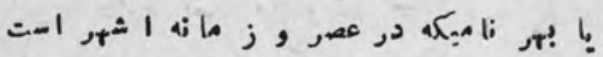

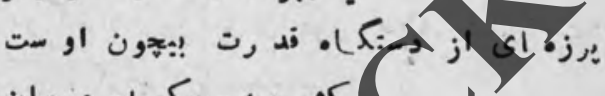

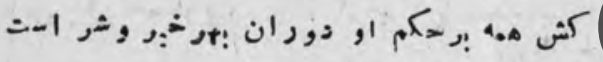

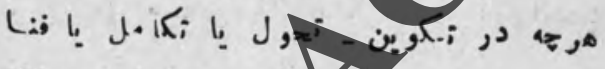

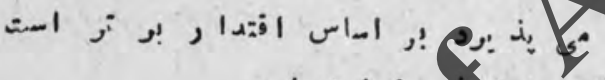

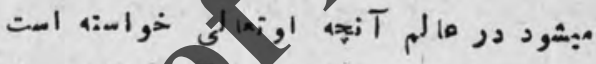

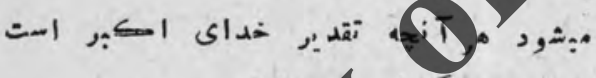

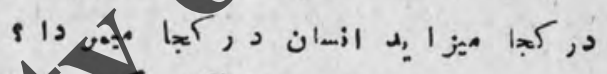

\&

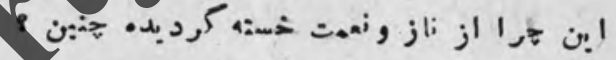

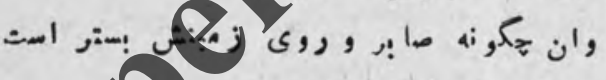

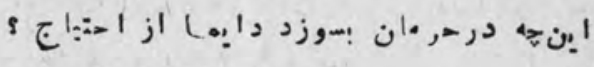

وان

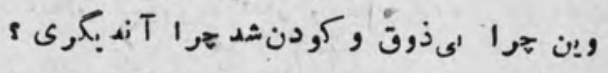

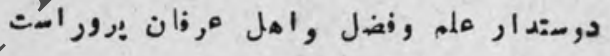

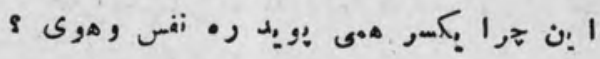

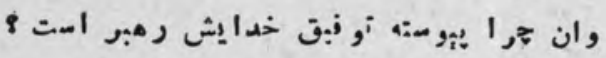

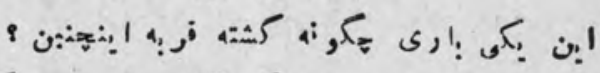

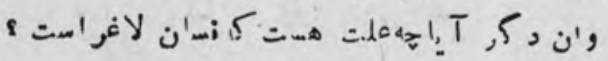




$$
=0 \cdot=
$$

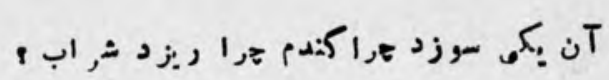

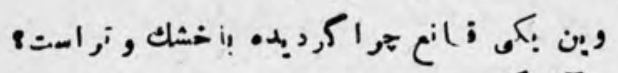

促

\&

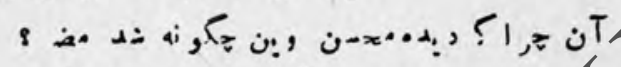

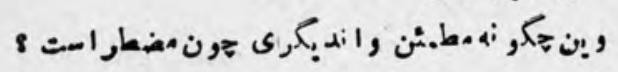

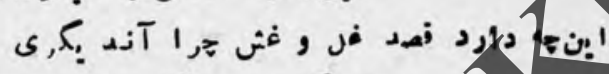

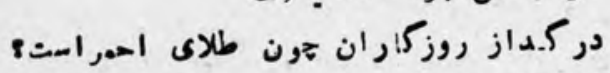

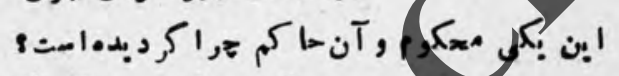

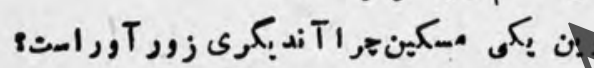

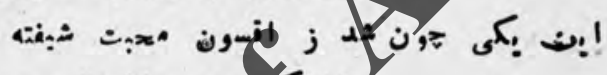

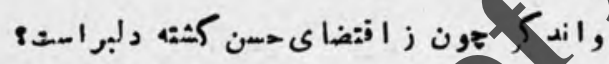

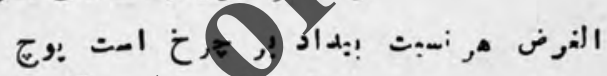

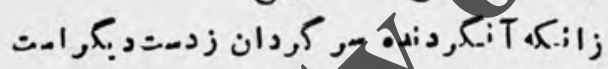

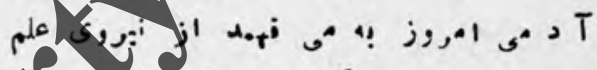

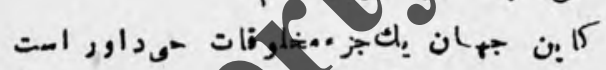

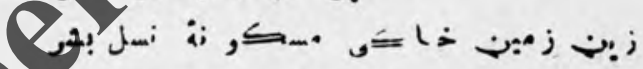

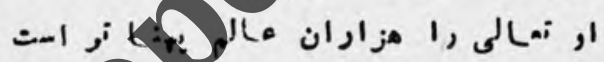

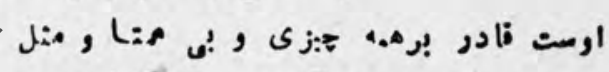

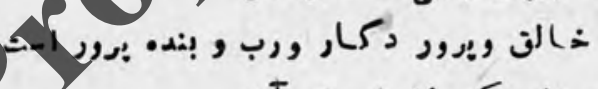

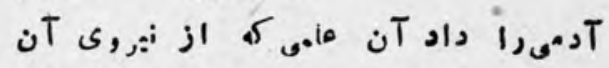

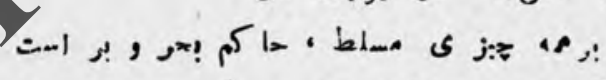

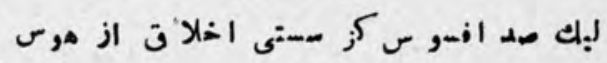

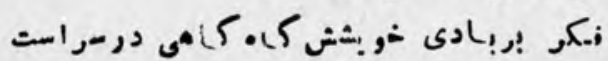

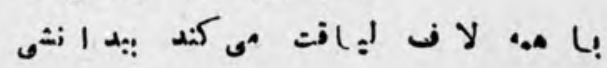




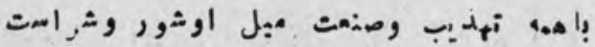

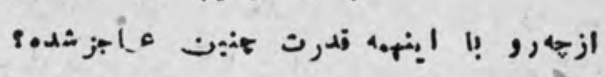

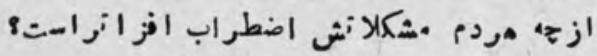

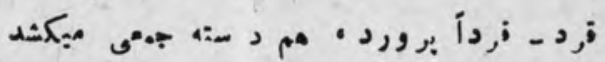

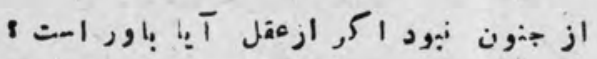

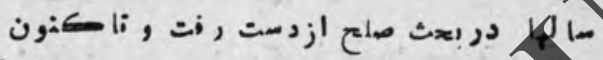

حسن i:

'

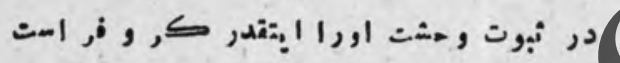

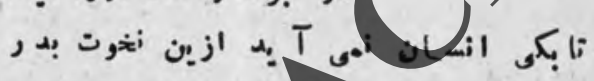

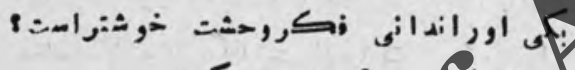

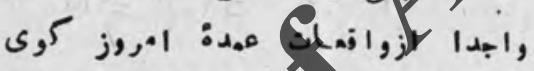

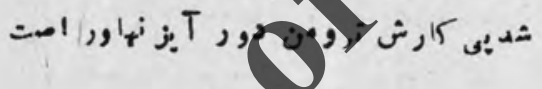

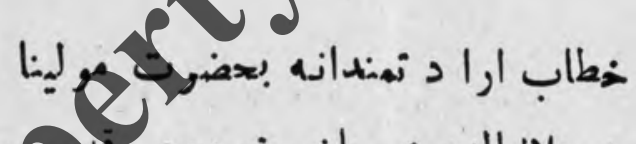

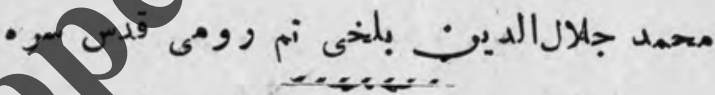

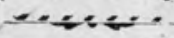

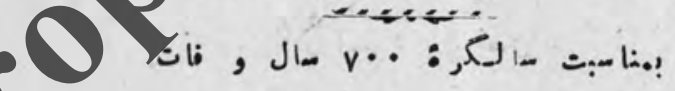

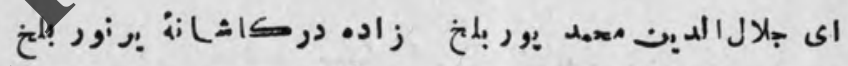

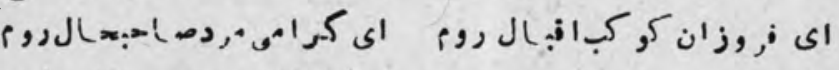

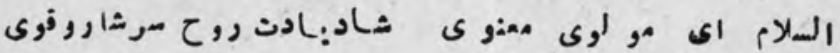

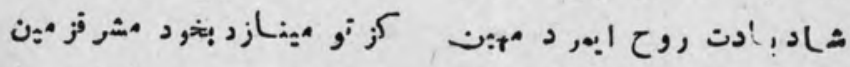

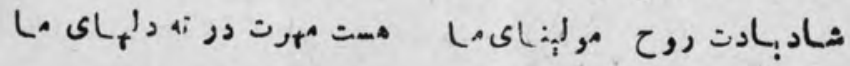




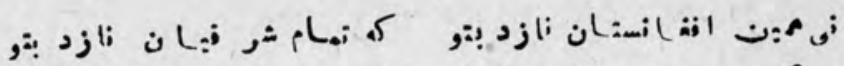

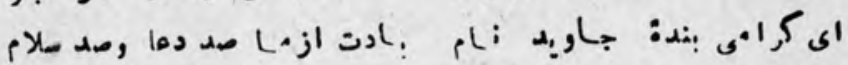

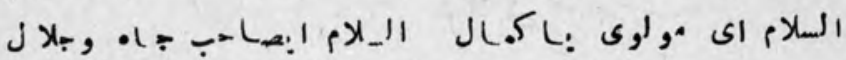

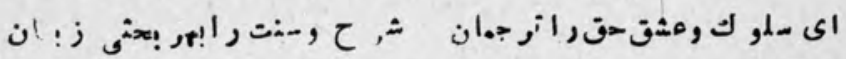

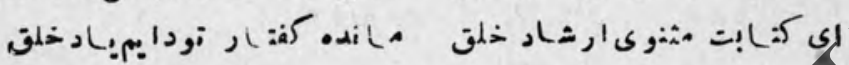

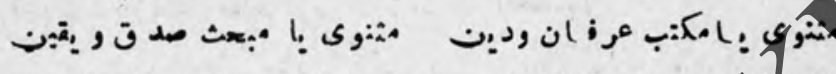

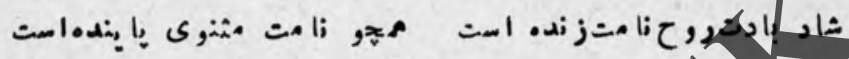

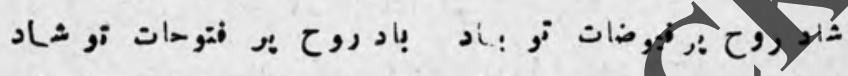

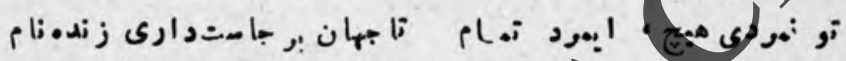

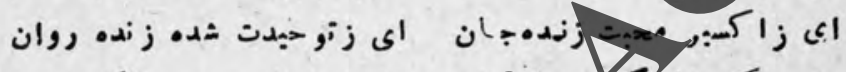

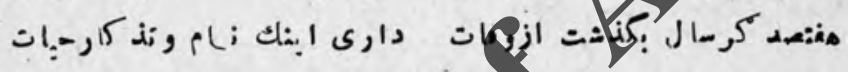

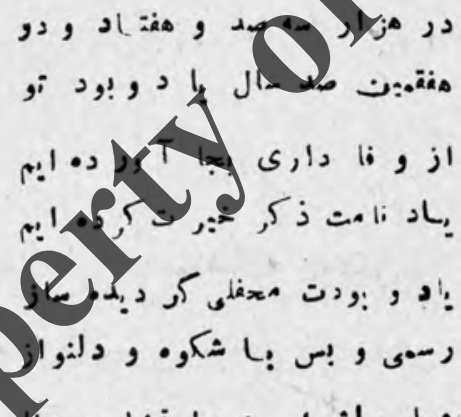

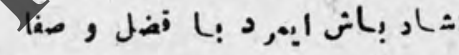

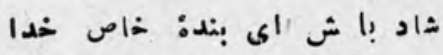

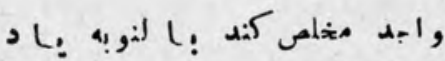
اى كراث

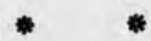




\section{دئه

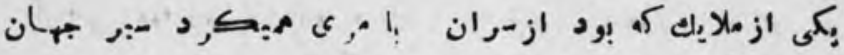

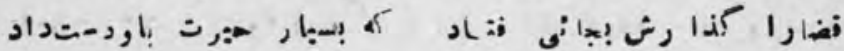

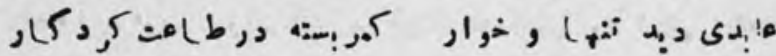

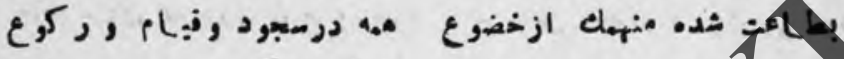

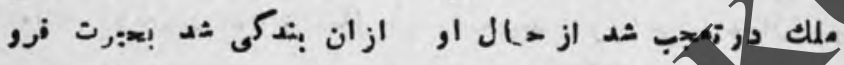

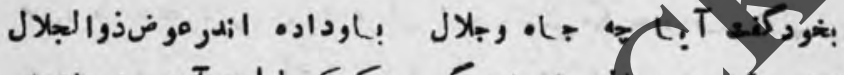

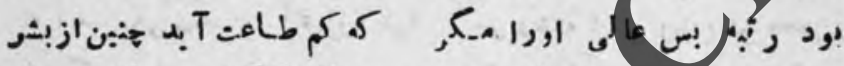

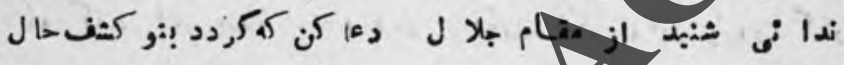

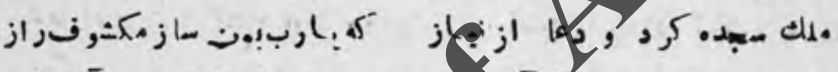

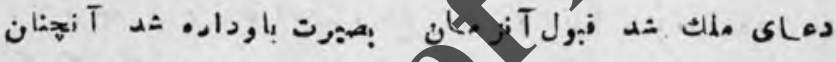

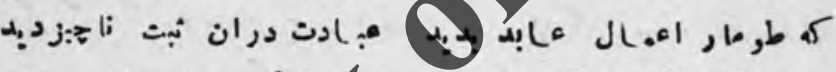

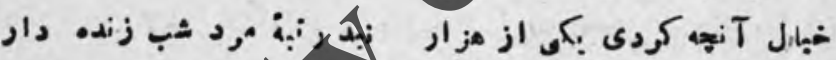

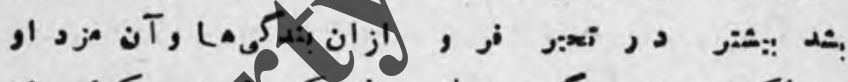

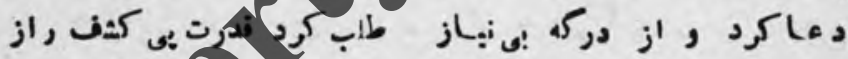

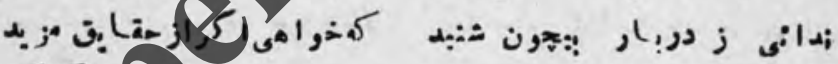

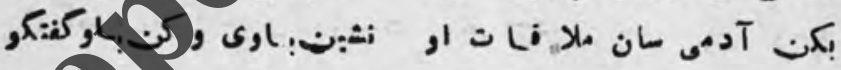

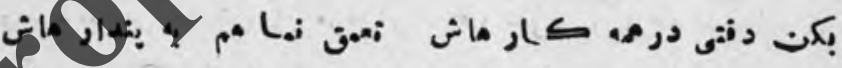

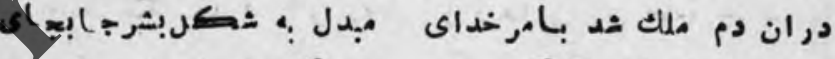
-وى دران

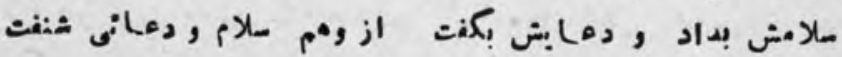

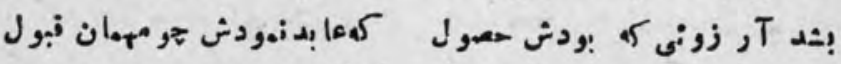

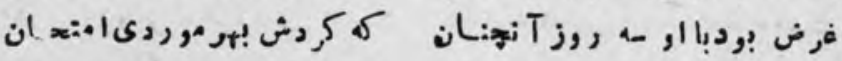

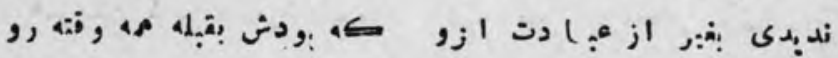




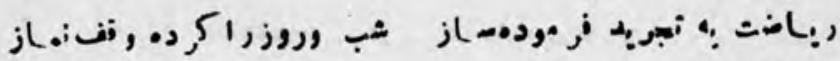

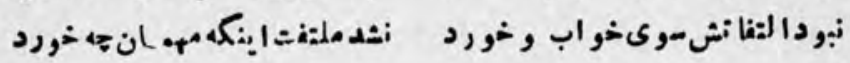

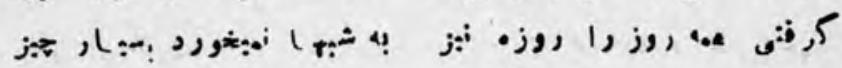

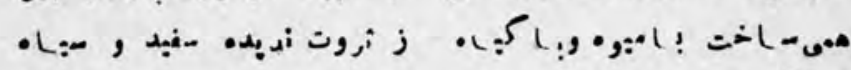

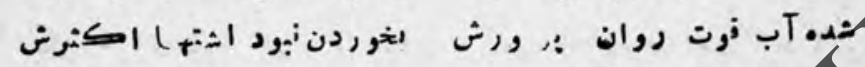

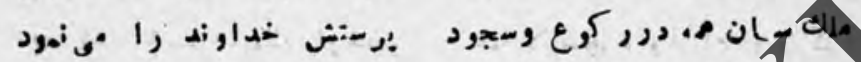

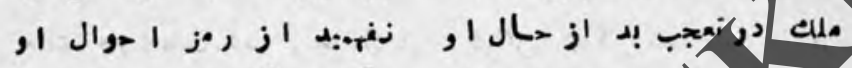

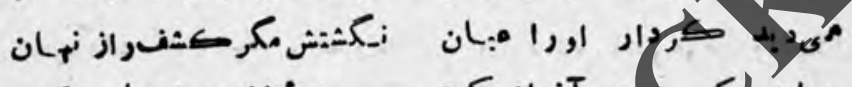

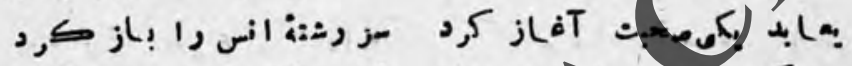

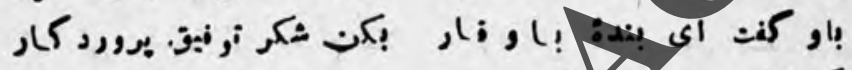

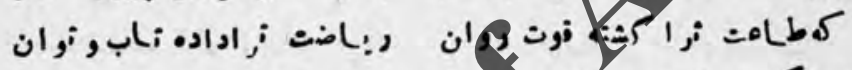

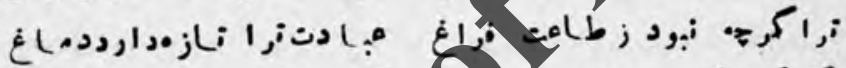

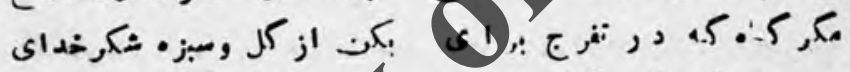

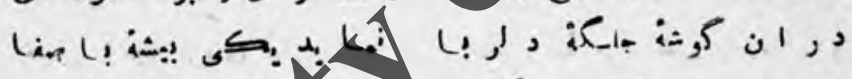

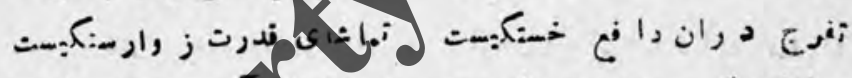

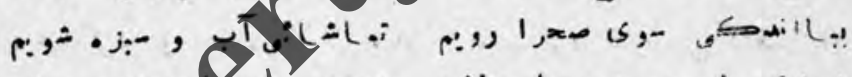

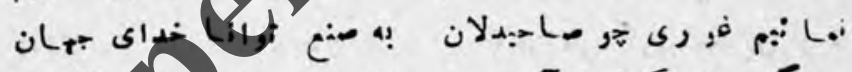

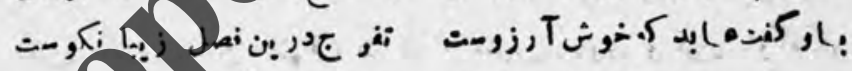

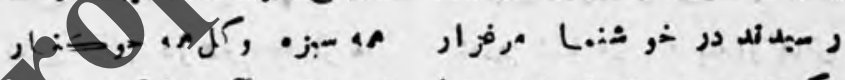

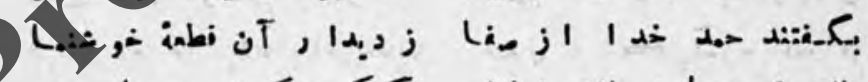

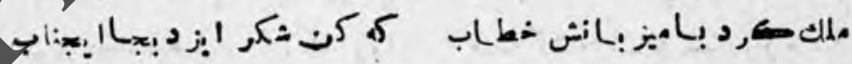

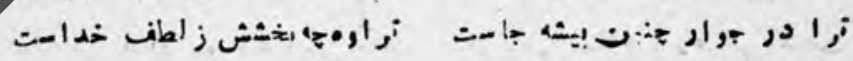

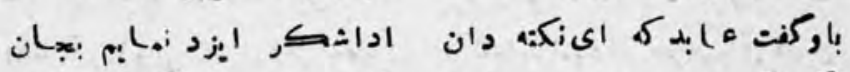

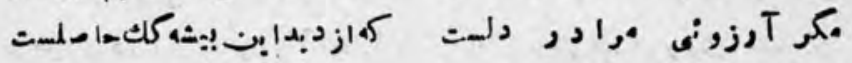

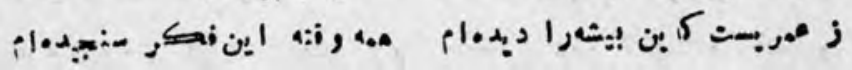




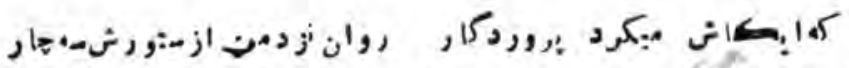

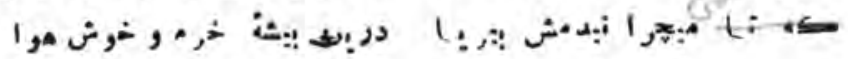

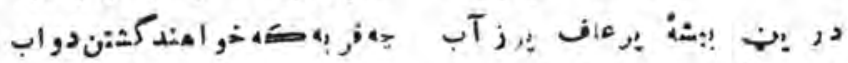

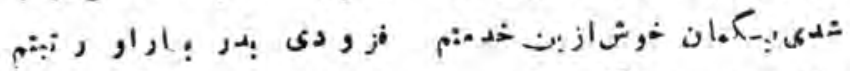

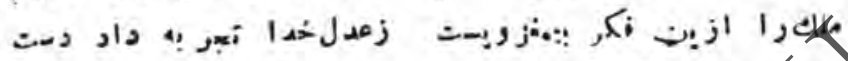

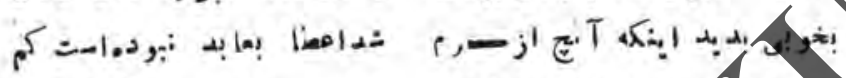
د:i之,

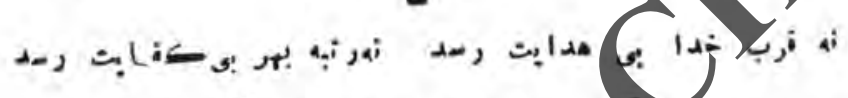

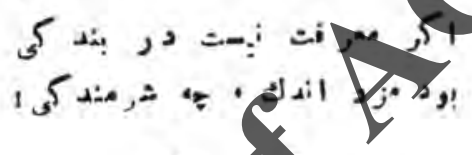

․ㅡㄴ
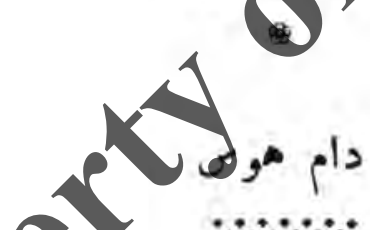

$O$

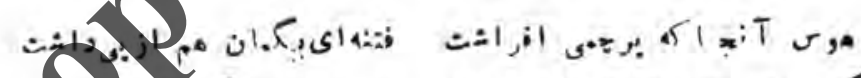

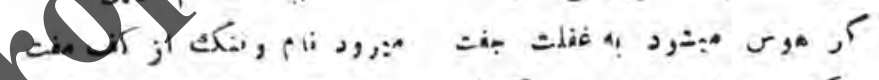

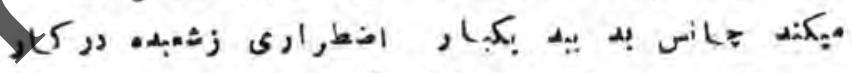

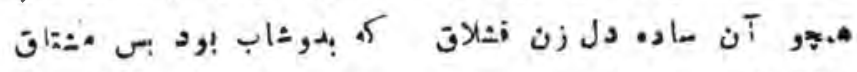

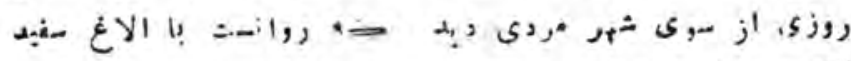

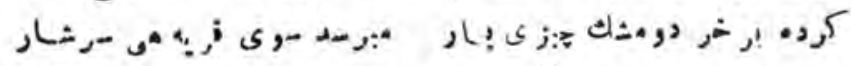

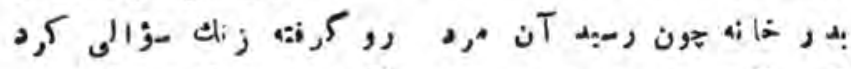
然 


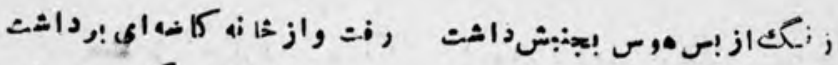

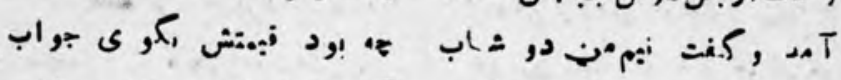

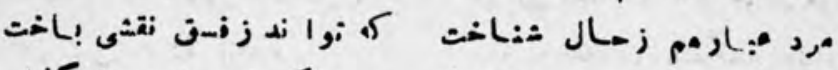

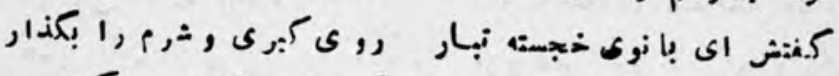

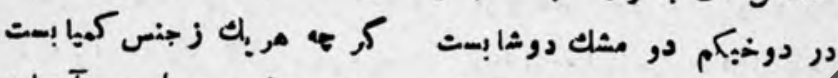
•

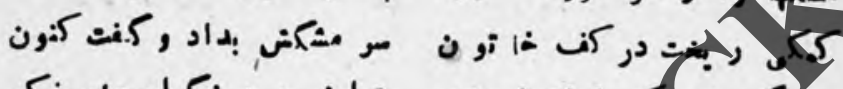

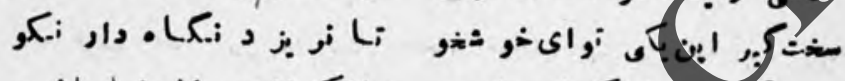

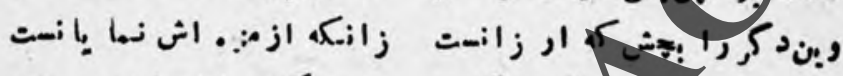

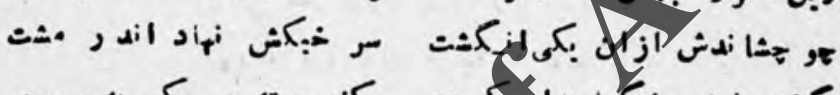

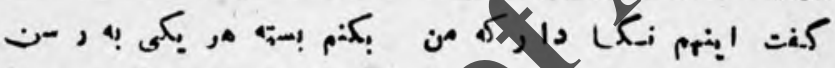

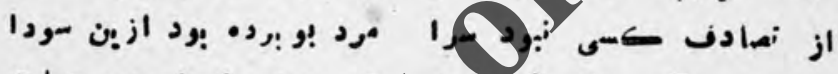

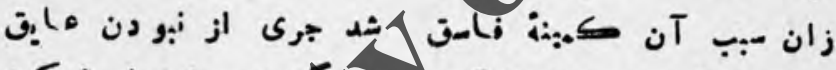

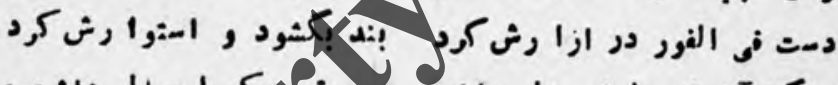

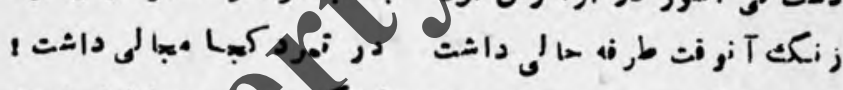

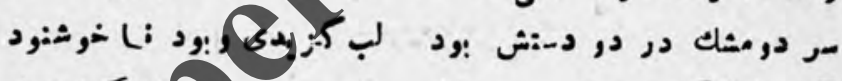

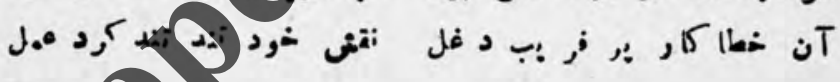

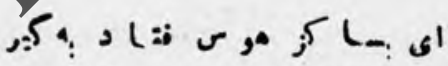

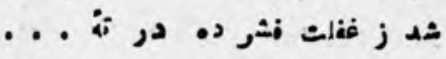




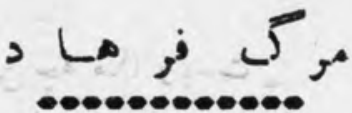

$$
\text { ا فن تير مر د يد و غر بد, عد }
$$

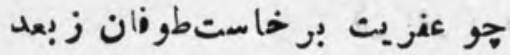

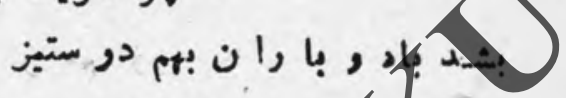

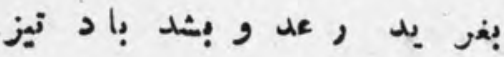

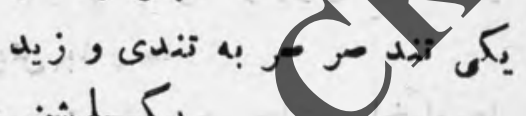

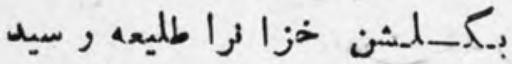

ز طوفا ن خوانئا

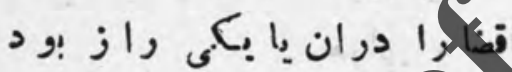

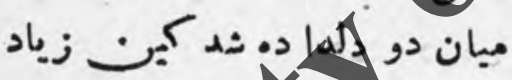

درين وقت عصر انفا في فتا د

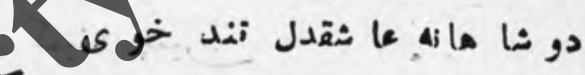

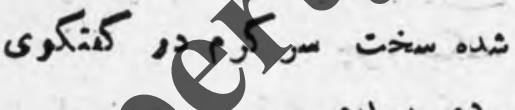

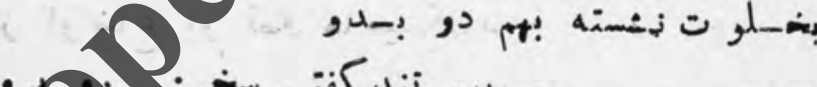

P.

$$
\text { زخسرو نو كنتى خرد رفته بوده }
$$

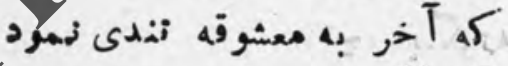

$$
\text { به شير.بن خود بعد آن آ شتى آخ }
$$

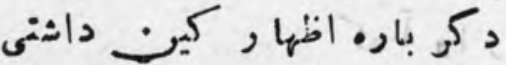

$$
\text { به شير ين خطا بى جنان ستخت كر }
$$

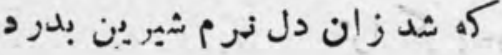




$$
\text { - ON - }
$$

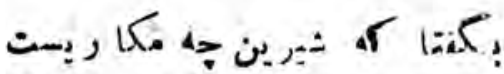

ز زباتت بهنطق مجب جا ريست

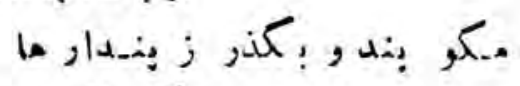

كن اقرار ر بـكذار ر انكار ما ما

تو نو نود بكر از از روى انصافكر

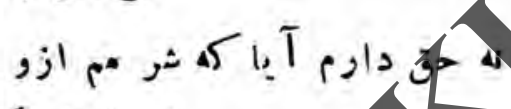

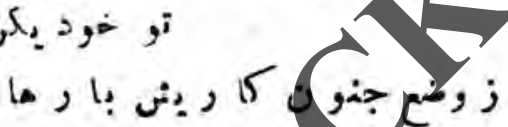

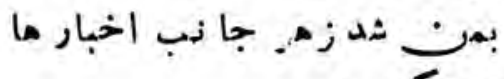

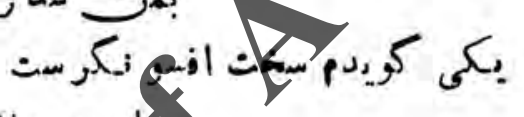

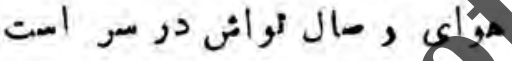

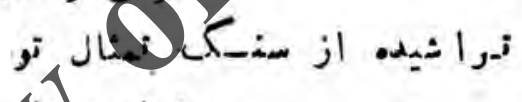

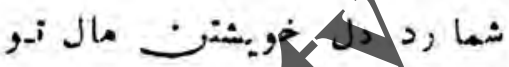

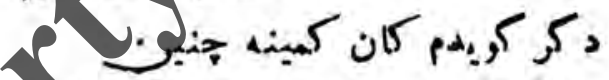

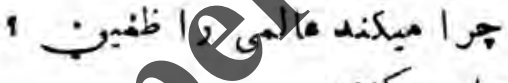
ز اوضاع او فه ها ميكيكند

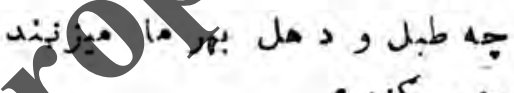

جه آخر در ين بيستون مبكنده

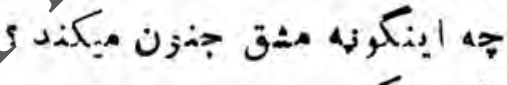

$$
\text { •- }
$$

كم آ وا ر. ابسرا بينم رقيب

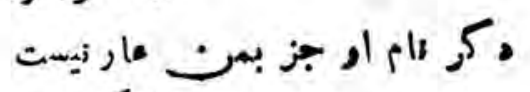

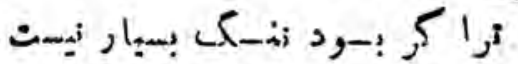




\section{نباشم مبـ ويا البا شهد خهور د او}

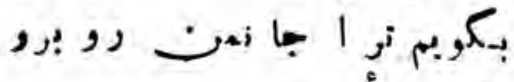

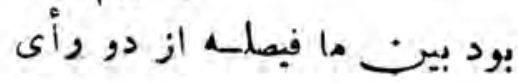

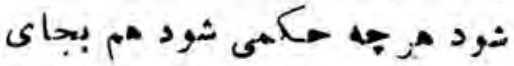

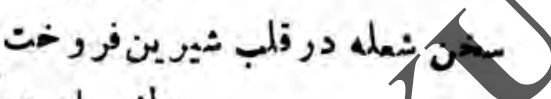

دار بار دي-كر به سختى بـرخت

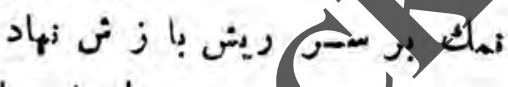

در اعها ب او اضط ادر ابق فتاد

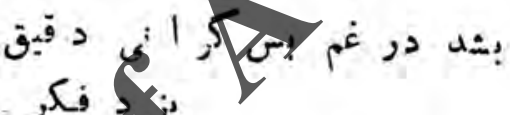

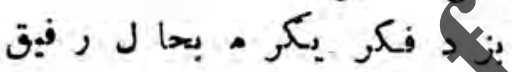

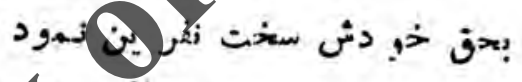

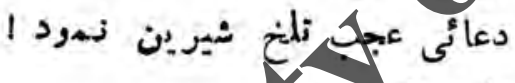

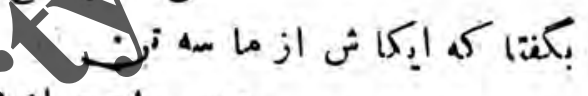

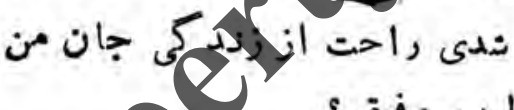

جكويم خدايا جو الب رفيق كا

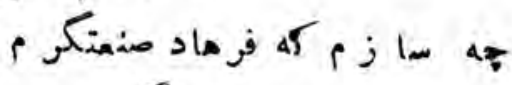

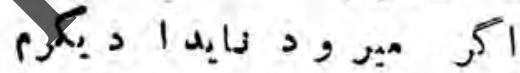

$$
\text { خدابا جه سا زم كه اد بإ رئم }
$$

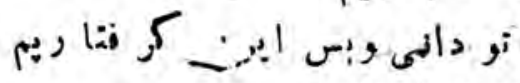

$$
\text { جسان كثته ناحجارم إئو الجلال }
$$

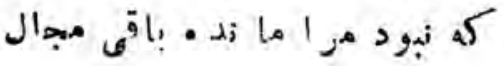


نوئى و اقفاى يُاك بزدان ز راز جها ن آ فريذا نوئى جارو...ساز

$$
\text { سه كنجه مرا مشكلم هست يثن ني }
$$

كه از فكر حلثردالم كثته ريش

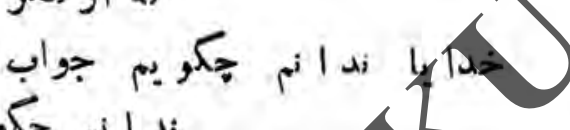

ند الم جكم جكو يم كه كويم صواب

كه خسرو به أندى خطا بث كهود

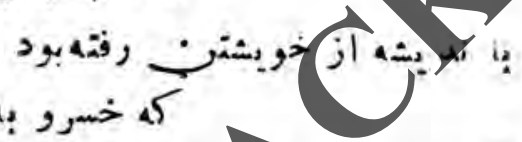

$$
\text { بكو جانمس يعلى خجد بيد ريغ }
$$

1

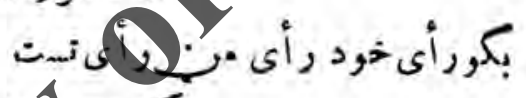

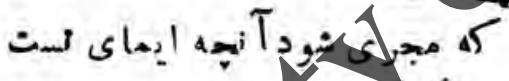

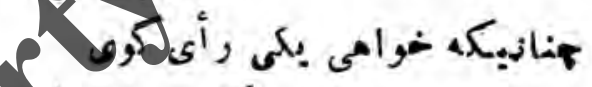

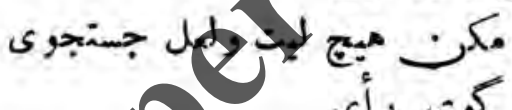

مزن طنر• جانا و بركوىى رأى ज小

بيكبار سيماى نيربئ كرزت

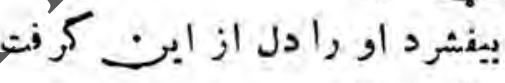

بكمن اي فهنشا. عالى جناب

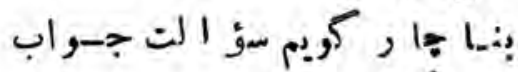

كأى من آنسه كان رأى نست

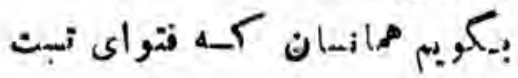


بكار نو كر خورده كيرم خطاست ولى يك سيخن كويمت كان بجاست

نو كردى دوين باببس سخت باى

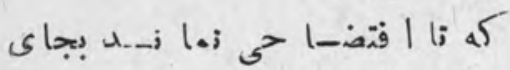

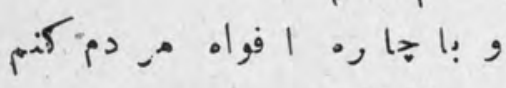
كه Tآواز0, 1,51

نمير كارك

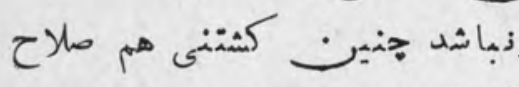

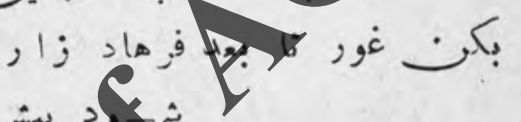

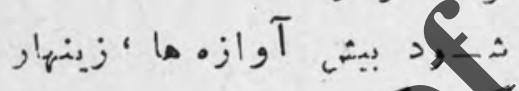

ازين حرف >

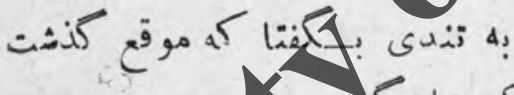

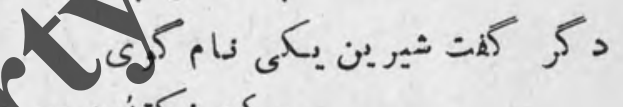

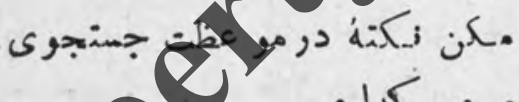

بكو, نا ز فرهاد يا مه كمام

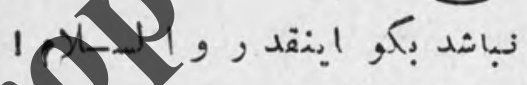

جو شيرين ازينكوزه اخطار شيد

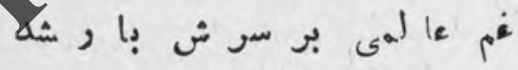

$$
\text { زدا نست ديكر ز بانش جه كأنت }
$$

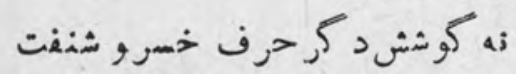

$$
\text { بحا لر كه جشمان او سته بود }
$$

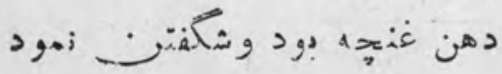


جنين ك5فت با يد زما i لد بجاي

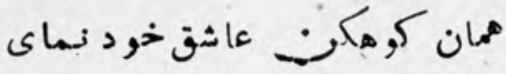

$$
\text { ز استا دى فن جر ا لا ف زد ؟ هان }
$$

كو عنقا جرا خيمه دروقاف زد

بمئح

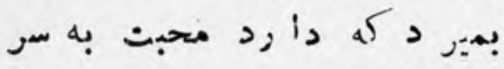

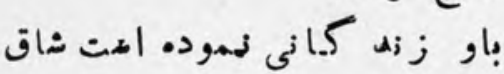

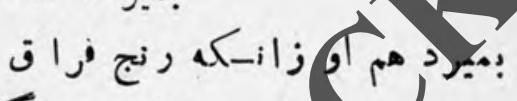

ب.

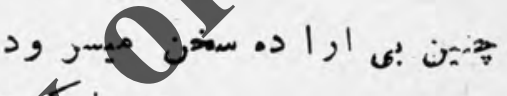

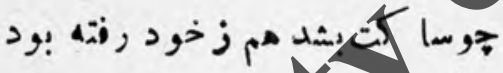

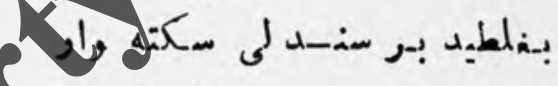

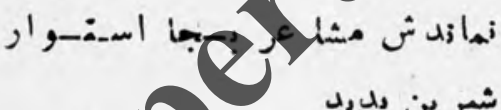

تو خسرو جنان حال ثبر ين بد بد

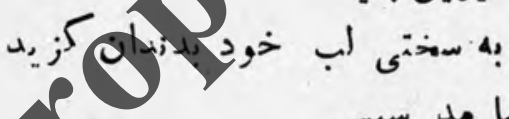

به آ هنته نا د ر بيا مد سيس

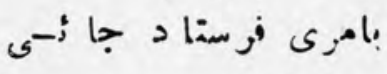

$$
\text { ز در باريان جند نن زيز خوازهـ }
$$

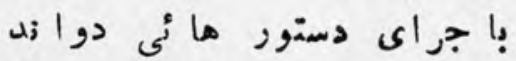

$$
\text { خودث آهد ودست شير بن كرفد }
$$

بزانزو س-ريار د دير ين كرفت 


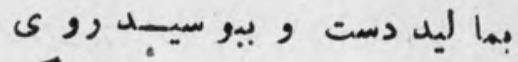
יגسن: د,

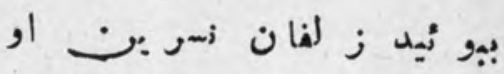

: ز

دو :

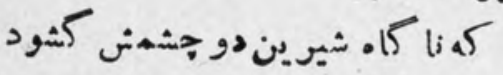

فل بشد درب با

درا مد :بكى قا صد و مده فو از

ب

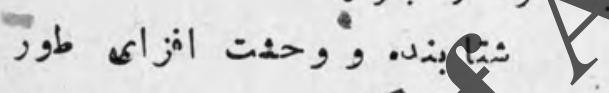

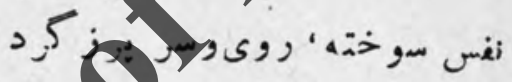

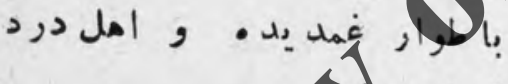

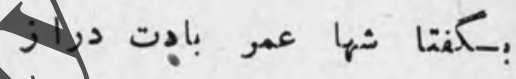

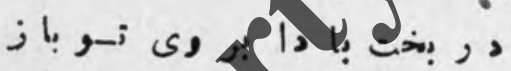

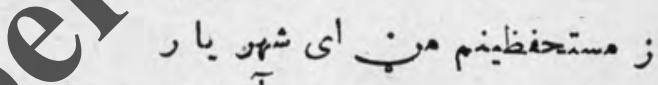

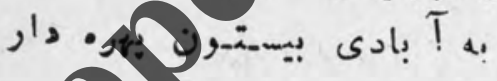

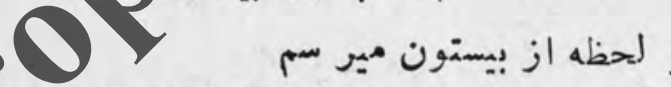

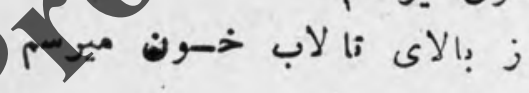

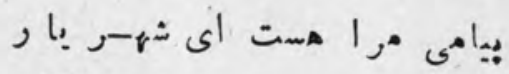

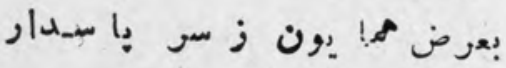

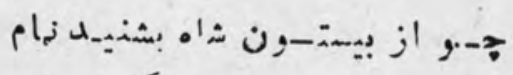

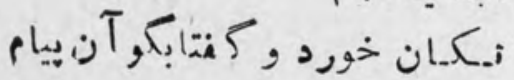




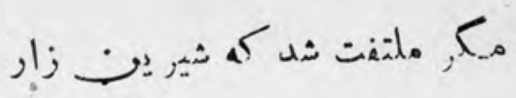

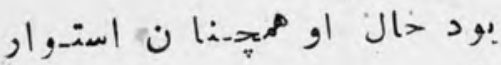

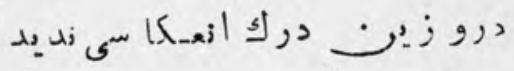

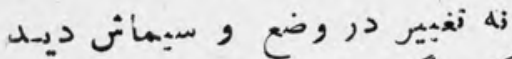
قاصد اجازت بـكنتن كمر فن

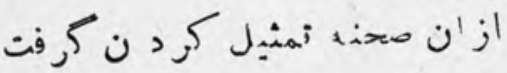
دست و بالا نمود

بسر زد كأه ضر بت بد ندينوضع بهود

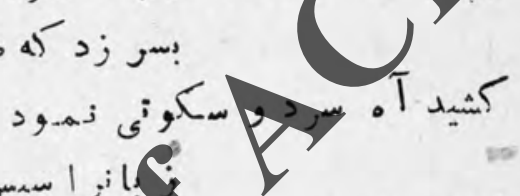

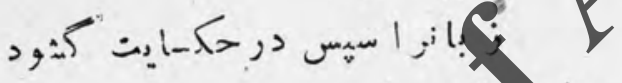

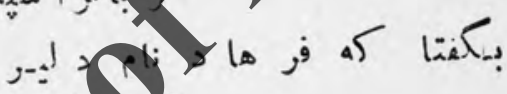

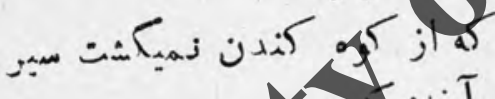

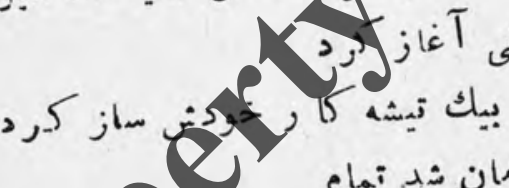

بيك ضرب كا رش ممان شيد تمام

है।

بنا كاه شيرئ بخنه • فتاد

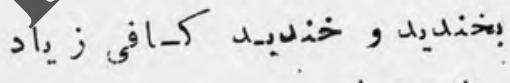

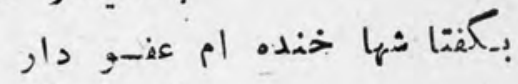

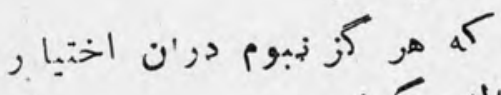

سيس دست خسرو ز الفت كرفنت

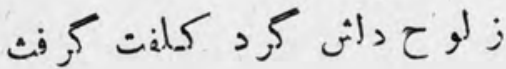




$$
-10-
$$

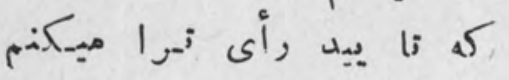

$$
\text { ** * }
$$

حادزه و ا جدا دست داد

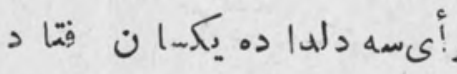

*⿻一𠃋火
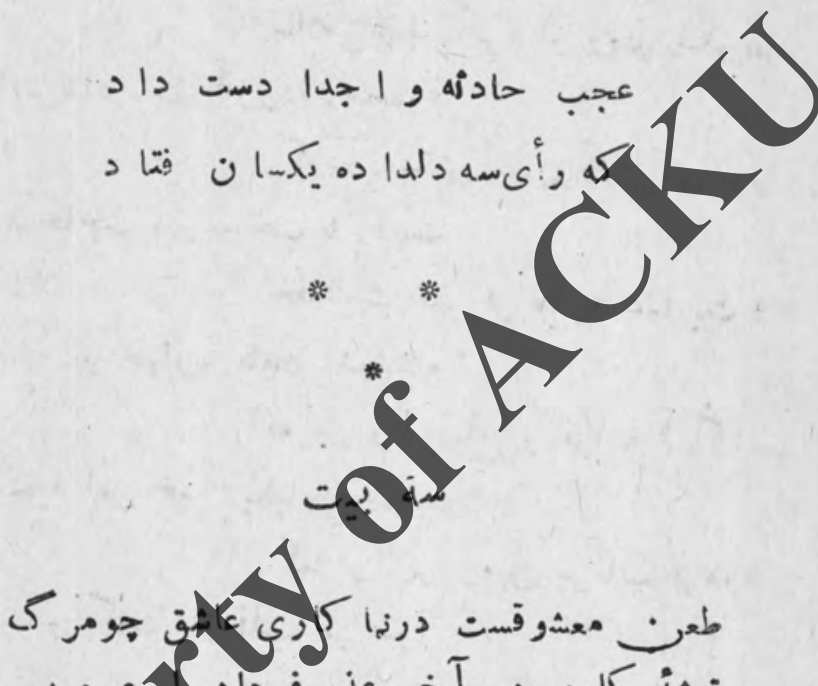
تيشة كارى در آخر عذر فرهاد * *

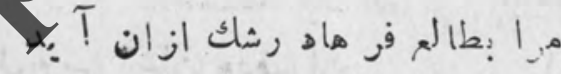

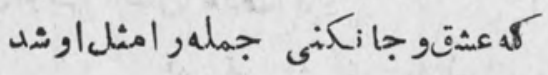
* *

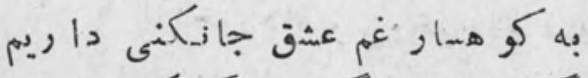

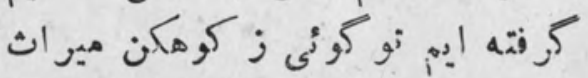




\section{$=$}

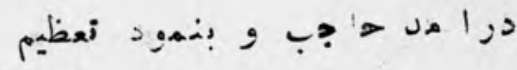

سلامق عرض كرد از رودى نكريم

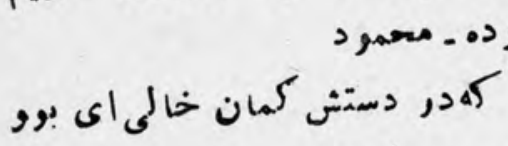

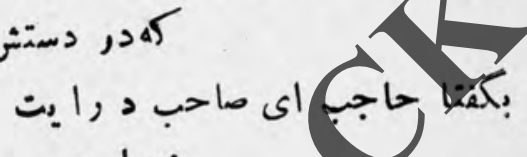

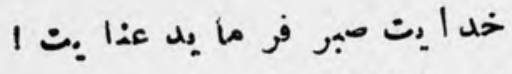

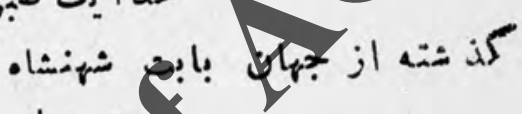

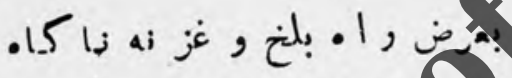

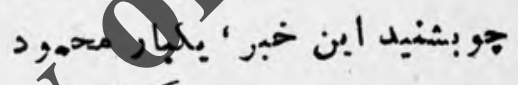

كمان نريجرئنين بر ناب فزمود

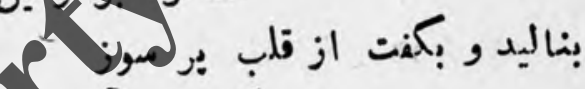

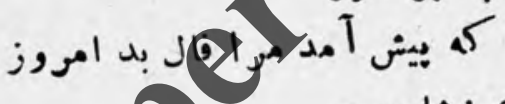

$$
\text { مين دم بود بر برج نشا بو ر آر }
$$

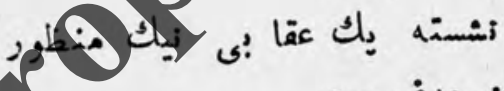

;ثنى سهل وبس آسان هدف بود

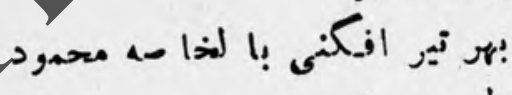

$$
\text { بعمب برنشان ثير اوليخ بار }
$$

نخخور دافسوسوخور دم غضه بسيار

بخا طر ثد مرا اند بشه ها يين

ز بد ييث آ مد م افزود نشويش 
براى إِذكه در نانى مد ف نيز

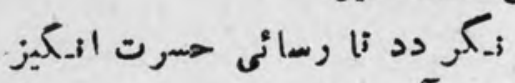

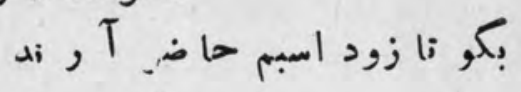

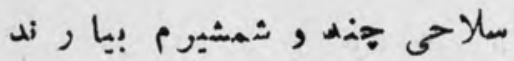

مأه بارى كنو نم جا نشيى است

هدف احر از أخت وات أزاج غزنيست

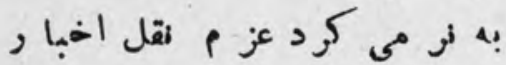

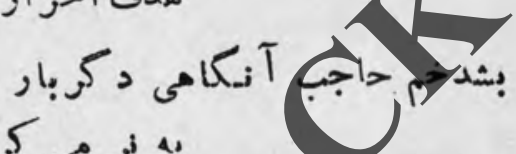

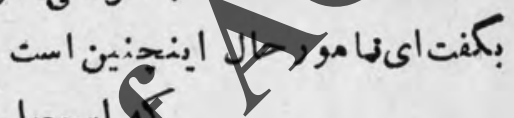

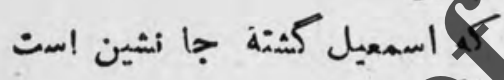

بحسب رلهم/إيلى بو قرار است

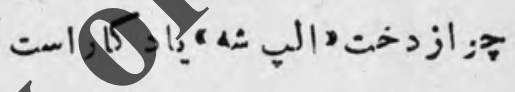$$
\text { و صيت كرد. در, حقن دي , ديتن }
$$

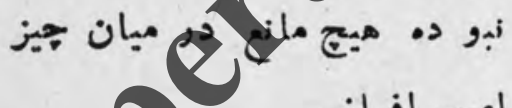

$$
\text { كنون بايست دازنست الى أسر افراز }
$$

كاخت كردام

$$
\text { بحق حضر زت داده است د ستور }
$$

كما كان سكو نت دور نشثا بور

$$
\text { ?aمهود اين خبر بس حير ت افزور }
$$

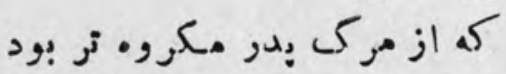

بكفت ازغيظ · إين واضح سؤ الدت از مرك

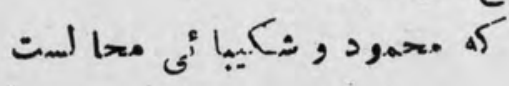




$$
=\gamma \wedge=
$$

$$
\text { مرا جز رزم آ,ائى هنر زيست }
$$

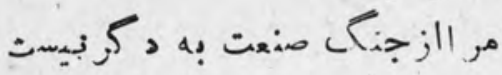

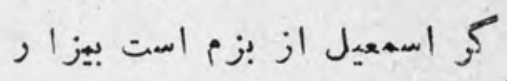

مر ا خو د نيسث بيز ارى زئم زيكار

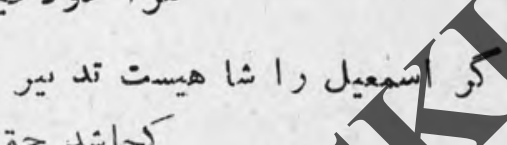

كباشد حق محمود جم' نـكير

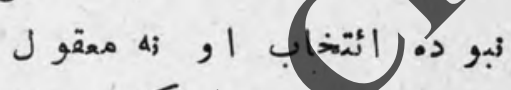

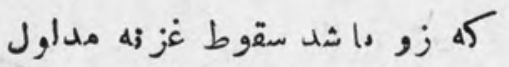

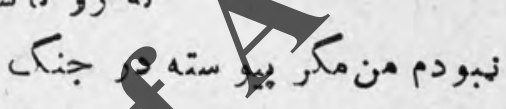

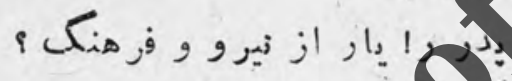

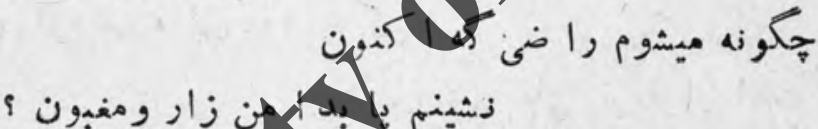

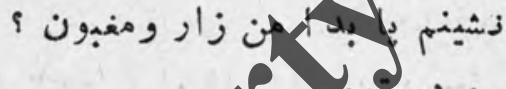

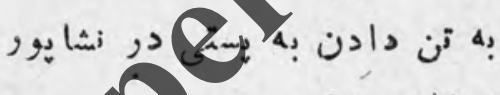

حه|سمعيل را خوشه|ده شاهيست كن

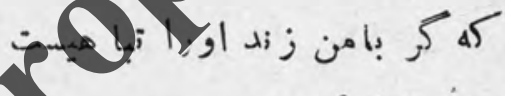

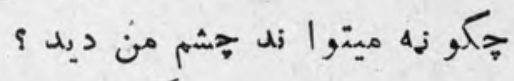

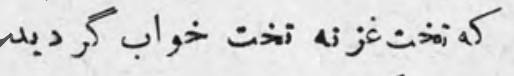

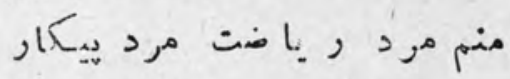

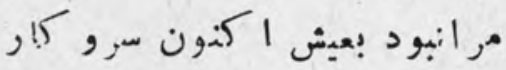

سنس حاجب بكفنت ازوضع مخججول

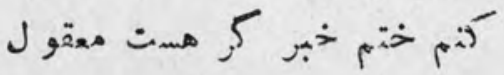




$$
=79=
$$

جو محمودش اجازت داد ككفتار

بشد خم زازمين حاجب دمكروبار

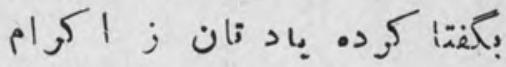

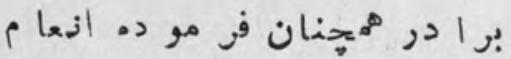

$$
\text { حار ز يما زن فر ستاد }
$$

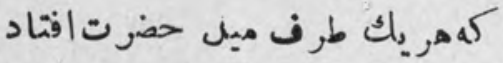

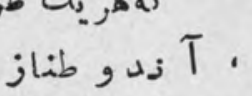

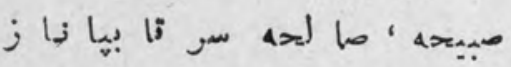

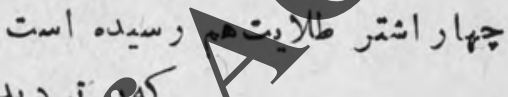

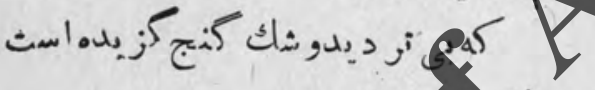

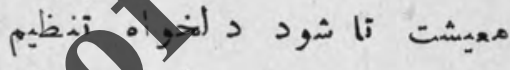

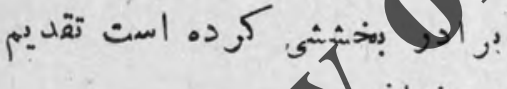

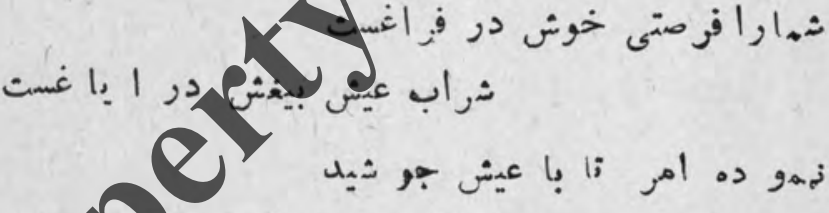

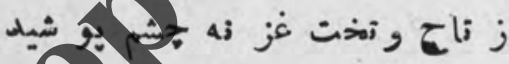

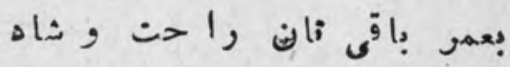

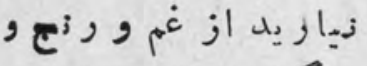

همه اوقات خود خوش بكذ رانيد

بر احت عمر را بإ بان ر سازيد

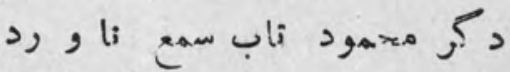

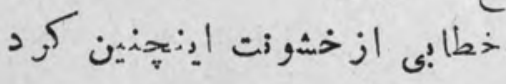




$$
\text { كماى حا جبز بان بر بند وهشدار }
$$

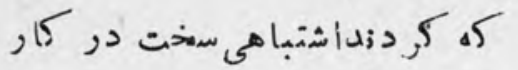

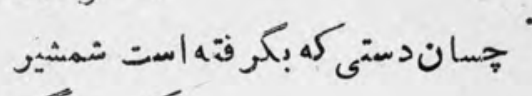

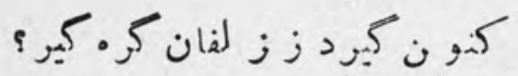

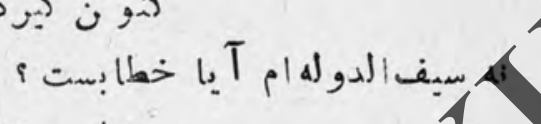

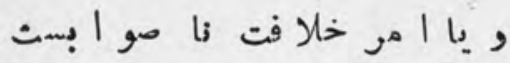

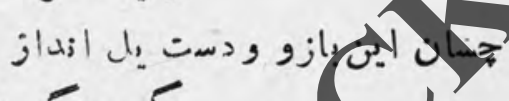

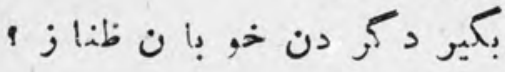

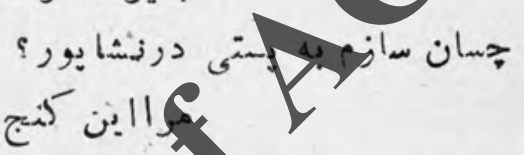

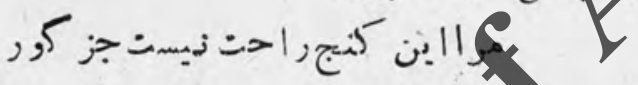

$$
\text { جو من بودم بهر }
$$

بكاجكيوفتح بودم دست هربار

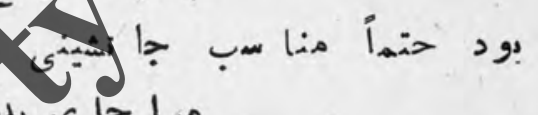

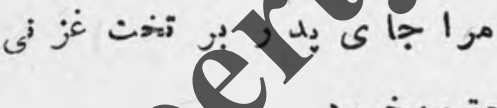

$$
\text { كنمثا بت كه زتوان حق من خورد }
$$

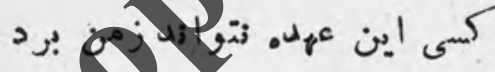

$$
\text { ك كر با ر• بشد خم حا جب بير اين }
$$

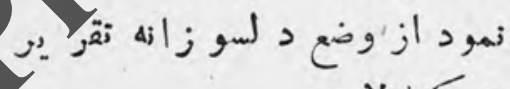

$$
\text { ككنة ايهر د ميد الن كما لات }
$$

جه حاصل جانكنى بهر محالات

$$
\text { جو اكنو انت مهيا عيث ونو ششت }
$$

هوس ميدان رزم آبا زهوثشئت ؟ 


$$
=\mathrm{VI}=
$$

\section{جرا إبد بريد از عيش بيوند ؟}

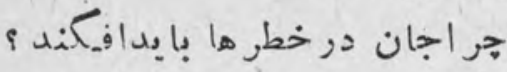

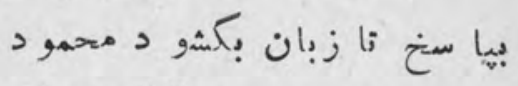

همان حل معلم إى جها ن بود

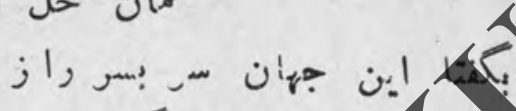

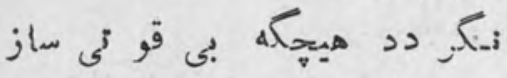

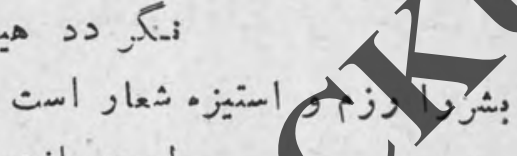

طبيعت بازد وخور رد استوار است

جأن ني زور وقوت جان زدارد

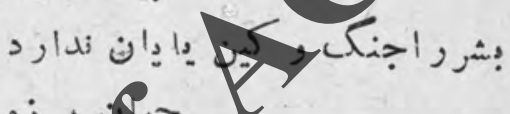

بشر ران

.

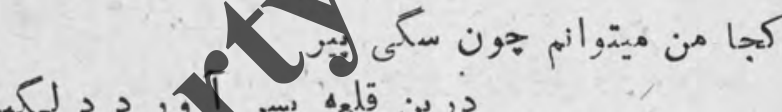

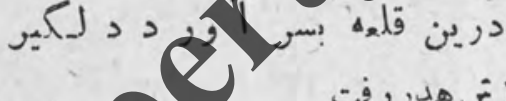

$$
\text { جوحاجبدين كازدر زن هلدر رفت }
$$

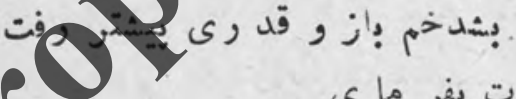

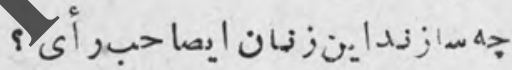

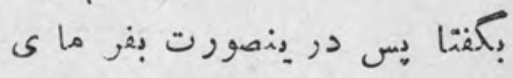

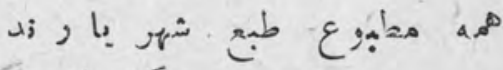

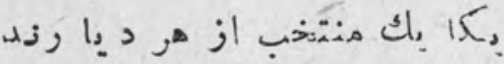

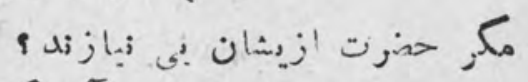

ز 
تزد دم حرجواب اينوقت مجهود

كه باخود با طنا دود در كيفتكو بود

بخوبى ملثفت شه هي ز فر هـك كانك

كهدر كار ثن بر ادوزد جهه نير نـكى

$$
\text { 年 }
$$

توائمحمود دقت كن كهز زينسان

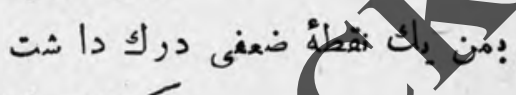

كها زن با زر بـ بـ اغورام بكماشت

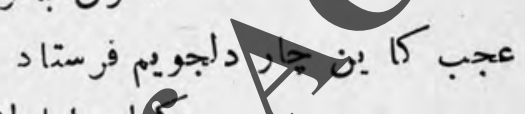

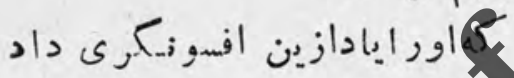

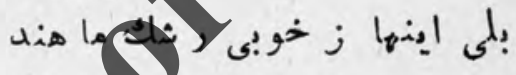

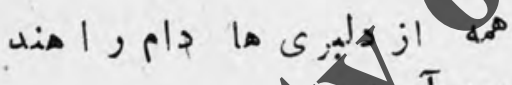

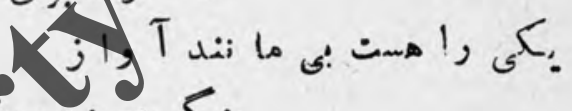

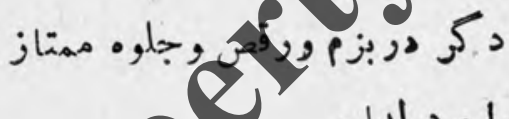

$$
\text { بود آن سومى دالخوا هد الدار }
$$

إ

$$
\text { بس 'زاختى كه دوازدبشه محهبرد }
$$

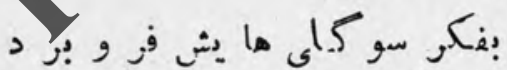

$$
\text { بكنت البهه ابنها نيز آيند ه }
$$

مرا خود ازعقب إنجاجهه دإيند

$$
\text { مكر بشنيد از حا جب دكر بار }
$$

جوابى از و قوف و كثيف اسر ار 
كه اى سر دار والاى سر افراز

بود معلوم من بى شبهه اين راز

كمز اسمعيل ايشان راست دستور

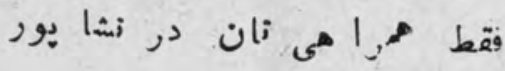

بر

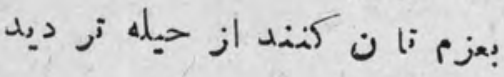

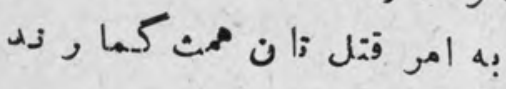

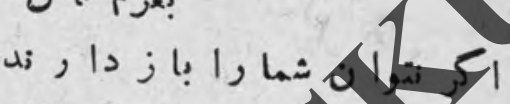

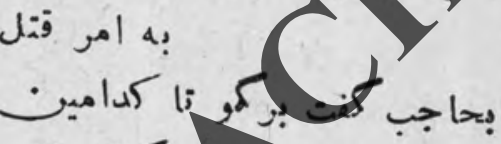

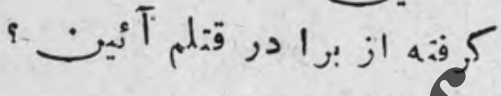

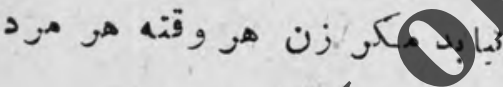

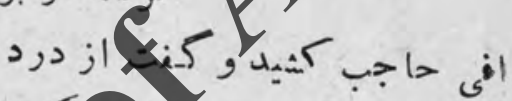

3مود. شاه ايشا زر إست نلقيرن

\&

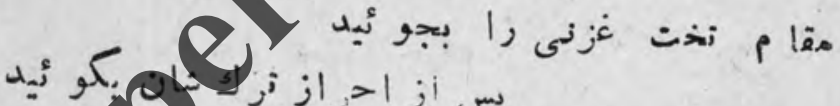

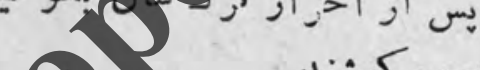

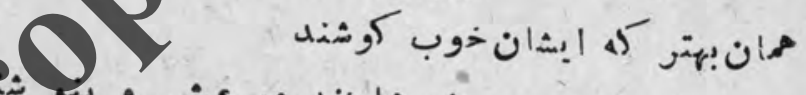

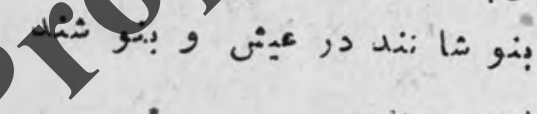

جيال ساطنت را از سر تان

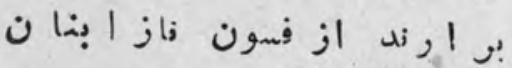

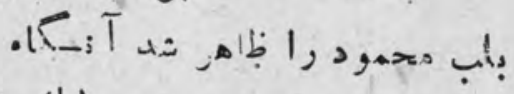

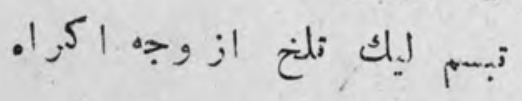


-

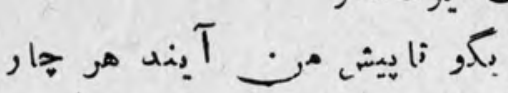

$$
\text { مراكر دروجين شاهى است نحرير }
$$

نيا رد كس ستردن حرف تقدير

$$
\text { مرادروجلب حق :رواى سرنيست }
$$

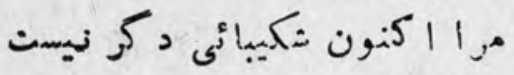

بثيلا جما جلمبرون وشددرورن باز

زبى آن جار سرو عشوب. بر داز

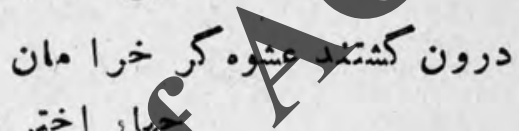

مجهار اختر در خشان ور فروزان

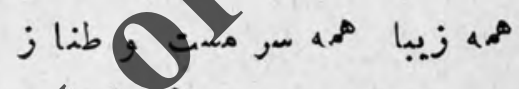

مانه

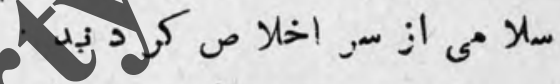

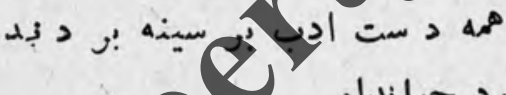

بس ازلختى كه محمود جها ندار

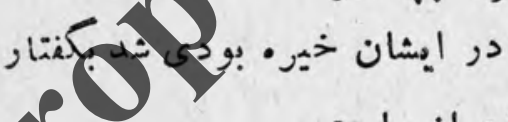

كما مين ازثها كوئيد از راست

بقصد كشتر محمو د بر خاست و

شده ما مور قتل من كما مست

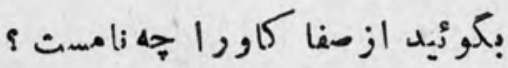

$$
\text { بها سنخ جهاكى كلى }
$$

زبا شد در ميان إينطو ر اسرار 


\section{سمال خواهيد مازد أند ر زشا دور}

ز تلخ وشور دور ان شادمان دور

ز ما هر مكك ور سم سأبق آ نطور

هعثي و نوش نان كوشيم از غور

شماثلا مريكى در هر خوشى باز

شزيك و و خدمتى باشيم و دمساز

كمانير الكه قبلا دور كمش داشت

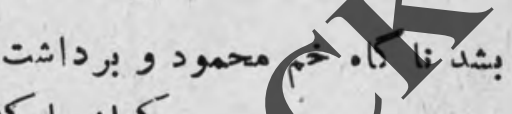

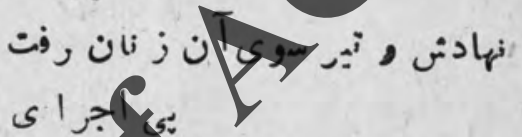

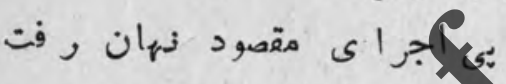

بكغة

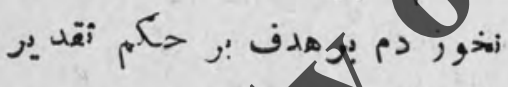

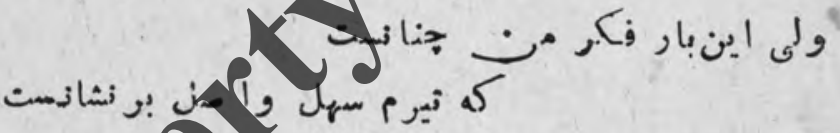
8

\section{ازانج| أيكله هركز قد ر تى نيست

$$
\text { ازانج| زيكه هركز قد ر تى نيست }
$$

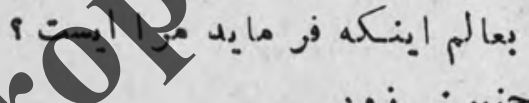

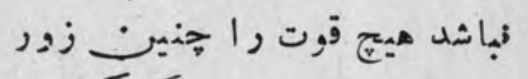

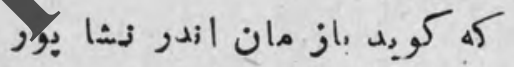

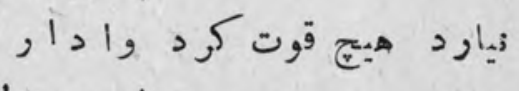

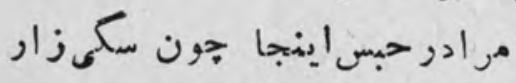

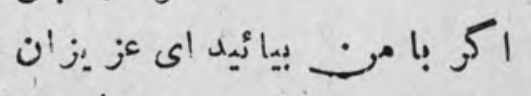

: 


\section{•}

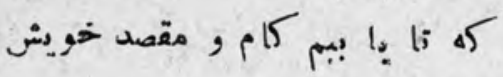

$$
\text { هـ ا هيدان جiكع و كارزاراست }
$$

شمار ا در حرم عيشى ورقرار است است

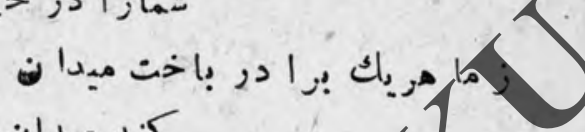

كند ميدان بديديكر خالى آنس آنسان

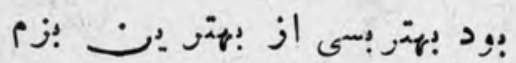

هنمجاج زكس

كمار ا ميد هم از دست ;

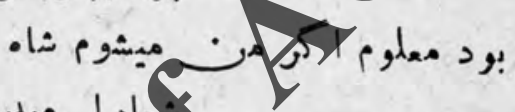

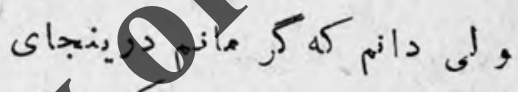

حأى

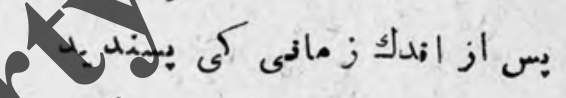

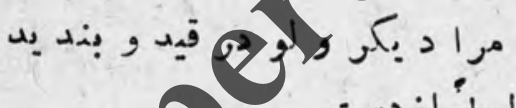

$$
\text { درا نصور ت شه! را طبعان ازدست }
$$

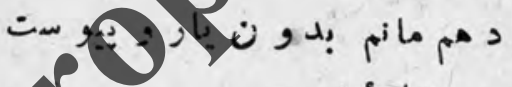

ثهما و قتيكه با من مى نيا ئيد

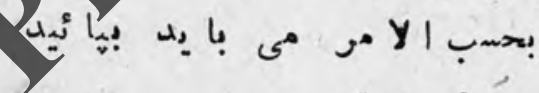

$$
\text { جومى بينم كه در هر صورنى هـست }
$$

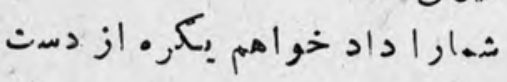

$$
\text { ما ن بهتر كه خود اينجا بها نيد }
$$

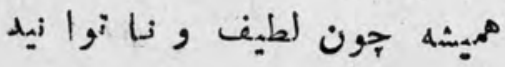


سيس جندبن قدم سنجيده بر داشت

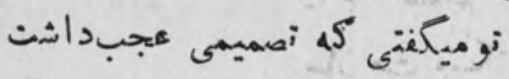

$$
\text { با هـشا ن قا هرازه اهر فر هود }
$$

بيك خط ايستا دن زود اهو از زود

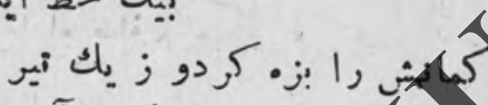

فيكند آن جارزن برون باحاجب يير

همنر بودن مهم تيرث بجا خورد

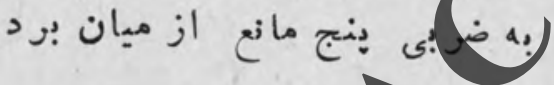

- $\cdot 2$

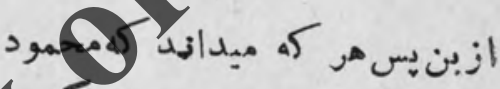

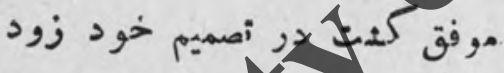

بشد سلطان وغازى بتشكن هنز

جي

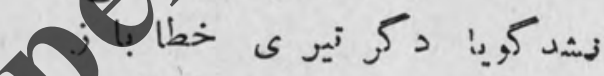

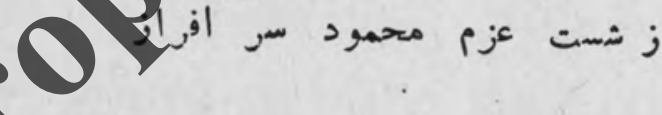

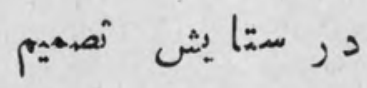

الا الى سايه تقديو يز دان

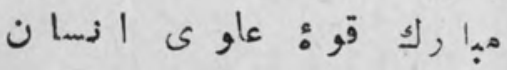




$$
=v \wedge=
$$
الا اى محرز هر كيام تصميم مت ميكم ز اخلاص تقد يم ترا او صاف ميكور ميكو يم در اخبار

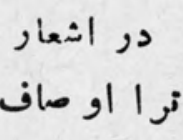
اكر واجن ترا واجد شود بين

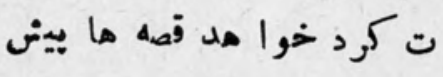

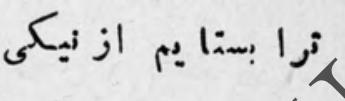
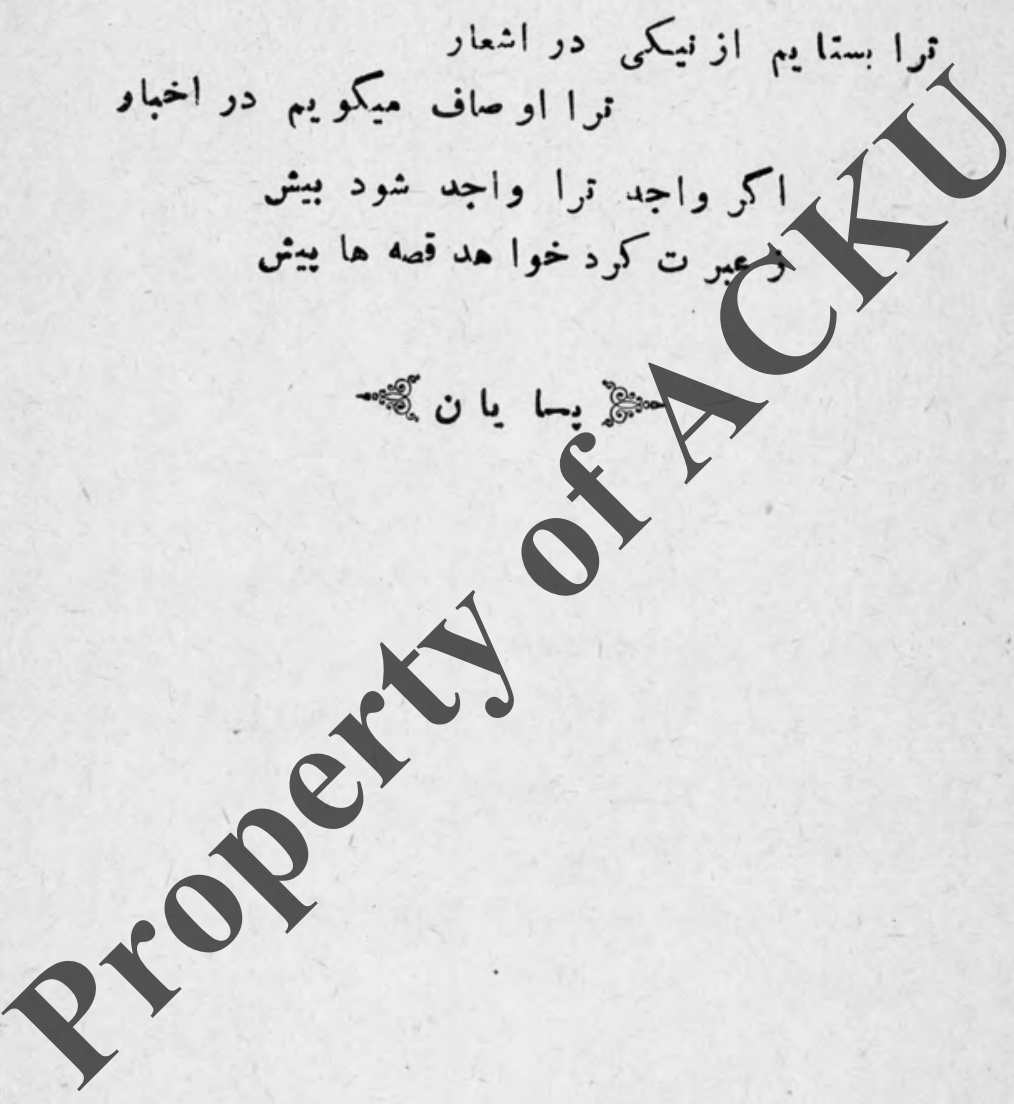


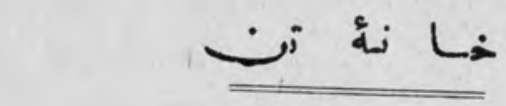

r

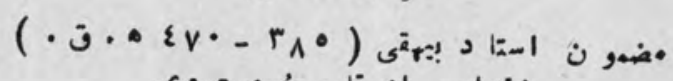

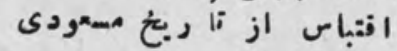

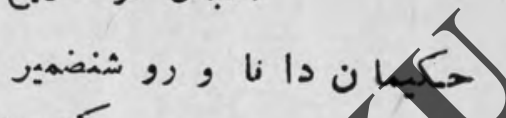

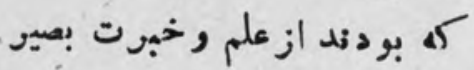

زاخلات وسعرث دور سفته اند

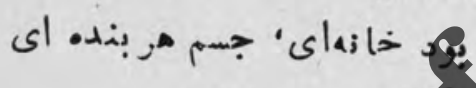

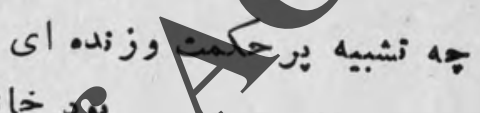

.

هورين خان

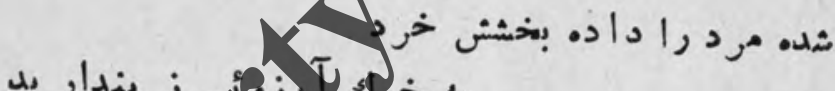
u ilis ; 4

O)

كا

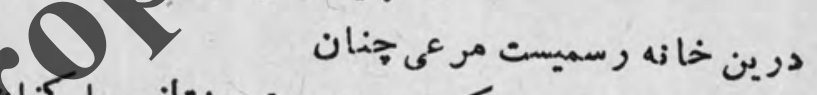

كاك

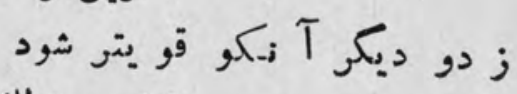

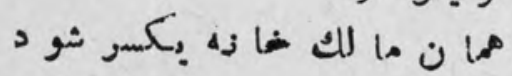

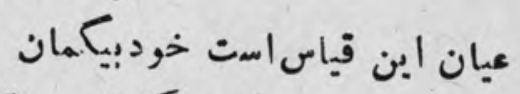

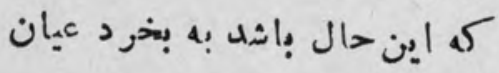




$$
=\wedge \cdot=
$$

$$
\text { كه هـر مرد بتواند از اقتدار }
$$

كند ضبط اين خازية را مرد وار وار

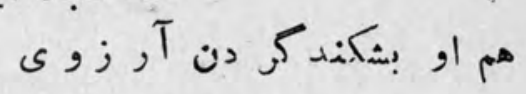

سيه حرص را سازد ازجهد ورى

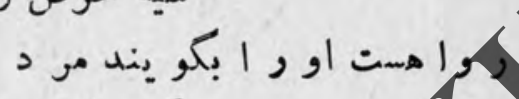

كه راه سعادت بخود دود باز كرد

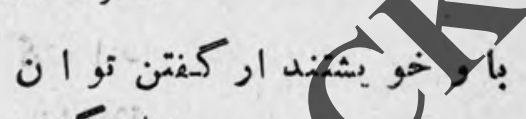

توان كتمنش مرد صان حب نوان

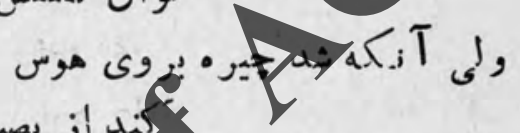

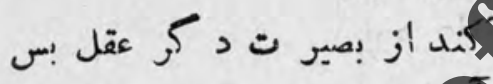

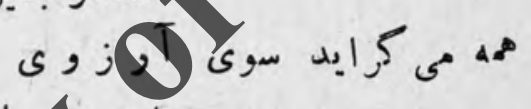

ن

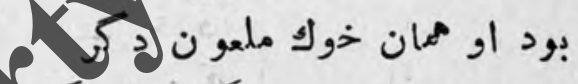

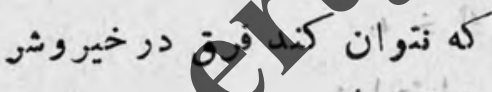

$$
\text { بود مالك خانه آن ز شتخ ثام }
$$

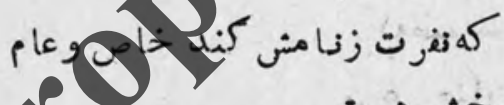

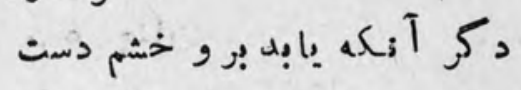

ثود از جفاى غضب سخت بـتي

$$
\text { جنا زيكه بر امر خشم ازشتاب }
$$

كرابد سوى كين و بغض و عتاب

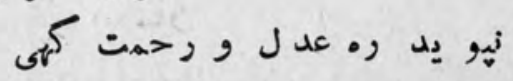

نيا بد بسوى مر ورى ته 


$$
=\Lambda_{1}=
$$

$$
\text { مركبانش آن مرد، كوبا جوشير }
$$

إ جراى خشم و خشو نت داير

جود طاعنى راكر ابن كمتككوى

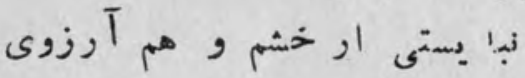

$$
\text { كان }
$$

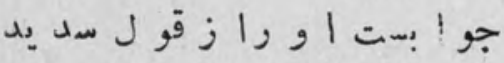

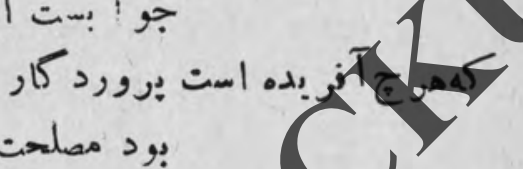

بود مصلحت ها د دران آ نيكار

$$
\text { بلى كر is }
$$

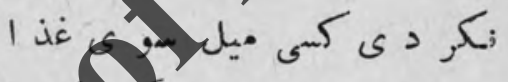

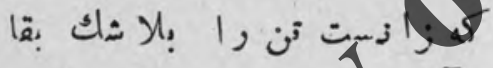

ك

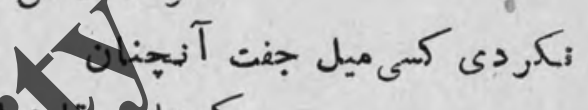

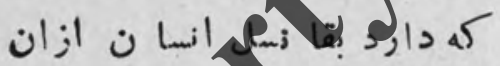

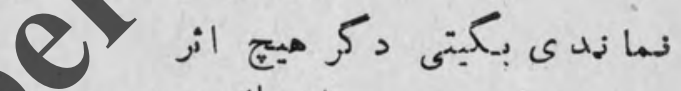

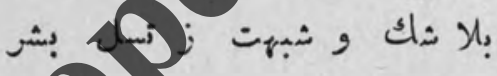

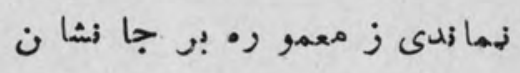

ثدى نيز و ير ان جهان بيكبلان

وكى نيز خشم و غضب زا فر بد

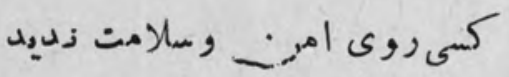

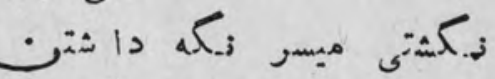

زنينكع وستم خوبثرا مردم وزن 


$$
\text { Nro }
$$

$$
\text { نبو دى كر از خشم وقوت سؤال }
$$

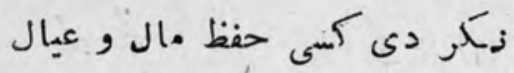

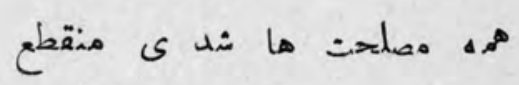

شنى امن وخير ازجهان مرنع

جنين قونى را و جود و حضور

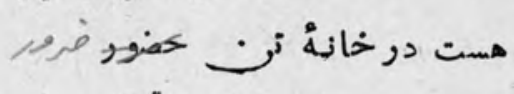


كم اين هر دو قوة بود د نمشفان

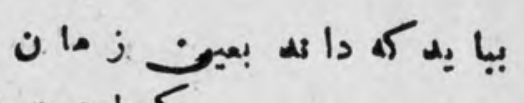

$$
\text { ازا3ند خصهان بر هكر و زور إن مرد }
$$

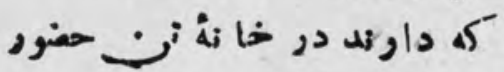

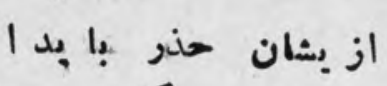

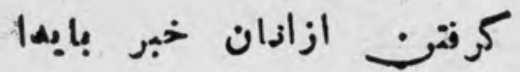

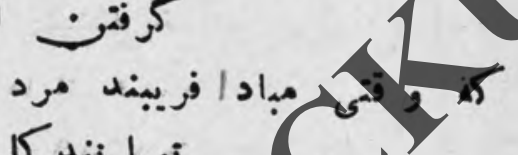

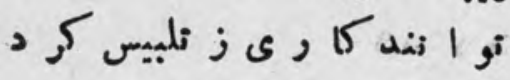

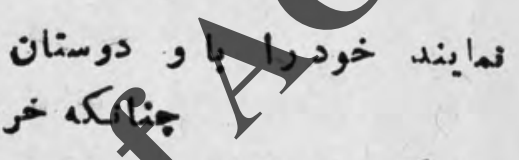

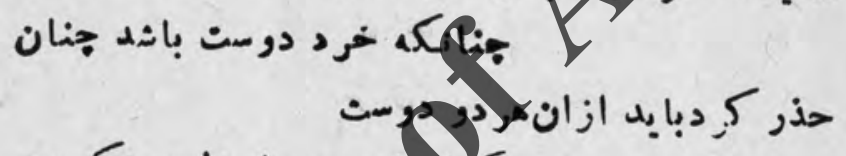

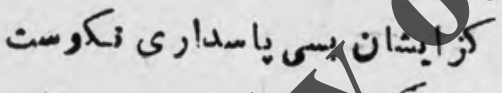

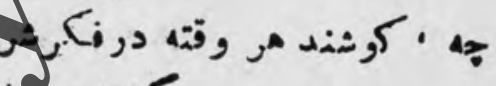

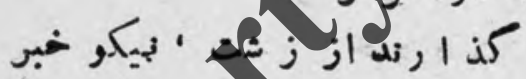

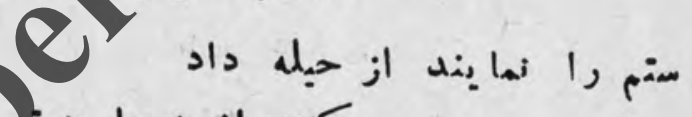

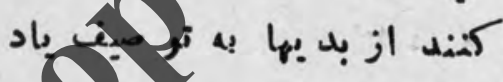

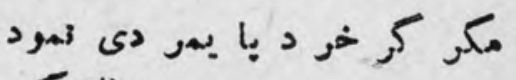

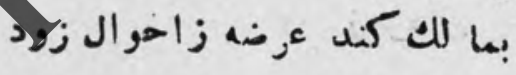

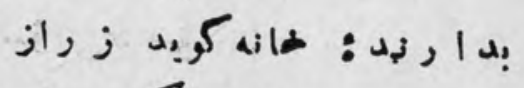

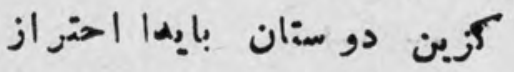

هرآن بند . راكز نواءا خداى

خرود روشن اعطاشه ه نيك رأى 


$$
\Rightarrow \Lambda_{i}=
$$

خرد زانككه باشد وفادار دوست كما يد باو آ نجه رو رات خير او ست

كمد عر ضه احوال هر كه بهرد

كه بايست كوشت بهرد به بهبود كرد

دا خبار ر بيشينيا ن

كذنته بخوازد جو روشن روان

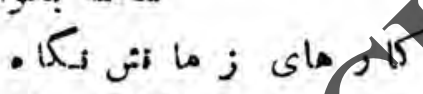

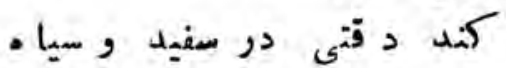

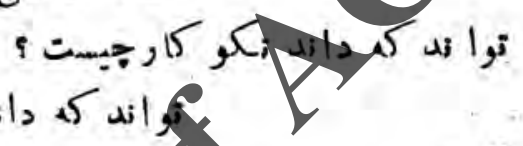

i

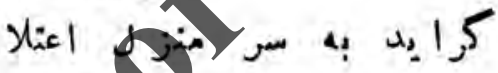

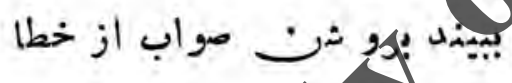

بيند سر الجام مردو لد قيق

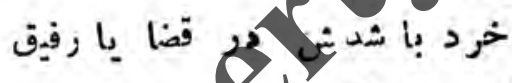

بر سد جها كم يند تا مر د مان

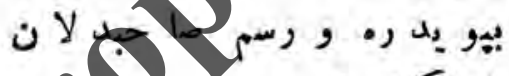

بجوبه جه ما3د نككو ي! د كار و

زمردان بد و ران بر كير وادار

در بنجا ست ديكر سؤالى د قيق

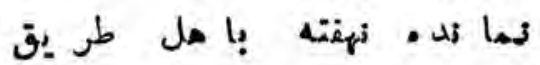

كه باشد بشر را طبيمت عجب

كر فتار در دامب دام صد ها سبب 
$-\Lambda_{0}=$

بسأ از خرد مند مر دان بود

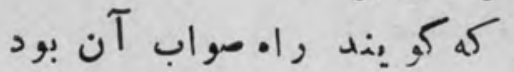

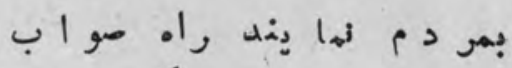

كك, بذد هر معذ رو ت زال جواب

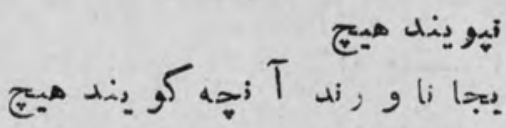

بكر :

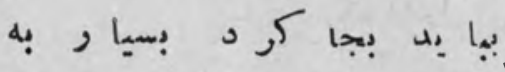

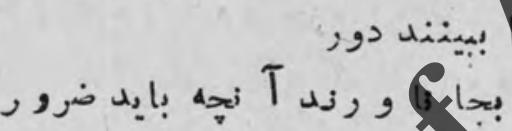

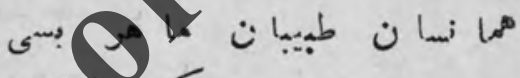

كi

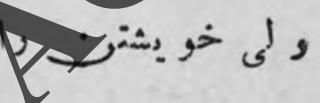

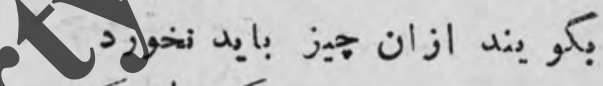

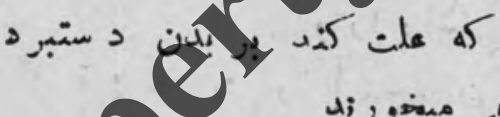

ولى خود ازان جيز هى ميندور

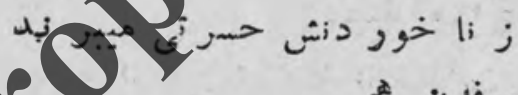

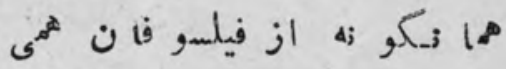

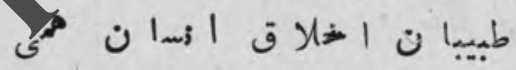

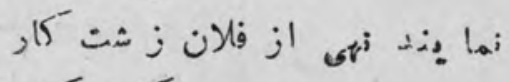

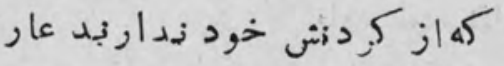

dij ز هis a

جو خلوت شو د كار ها ها ميكند 
بس مر دماننه در روز كار كه هـتيند زادان واز جهل خوار

$$
\text { زدا زند از غور , غارت اهور }
$$

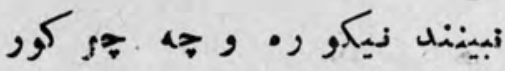

ئزلان خواند معذر ر ابن مردمان

كه هـتشند از جهل خود نيانوان

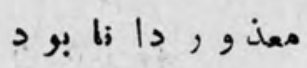

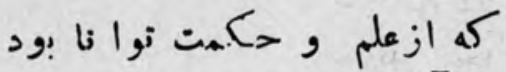

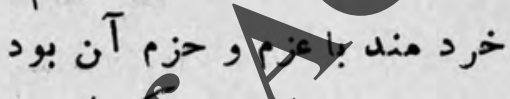

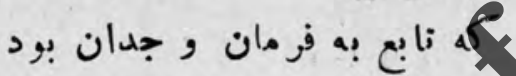

هم از رأى روشن كنه رمتجوى

رمى كالزن صوا بست بى كمنتكوى

ز دل بك مميشه به جمعيت لهست رحي

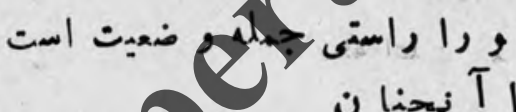

اكر قو: خو يـ رآ بزينا ن

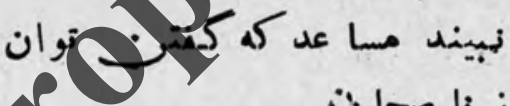

تنى جند بكز بند از نا صحا بن

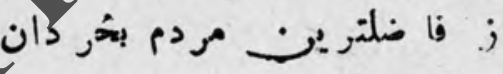

كه او را عيو بش كما بند باز

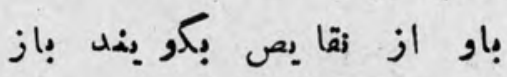

$$
\text { جو اور است بارى قوى دنشمنان }
$$

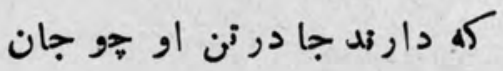




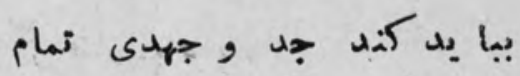

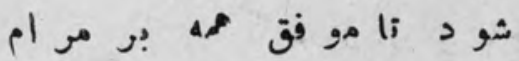

$$
\text { وكر عا جز آيد بـ بـكر و توان }
$$

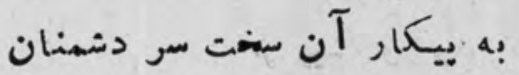

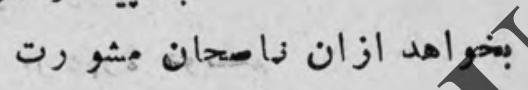

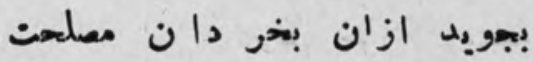

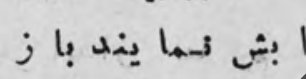

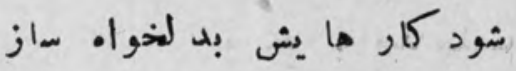

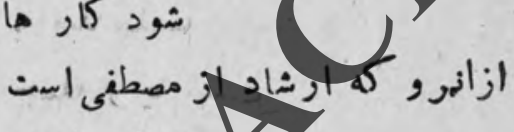

مثا

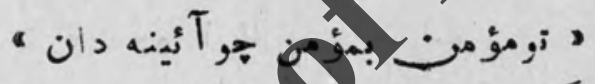

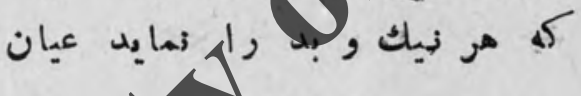

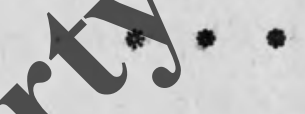

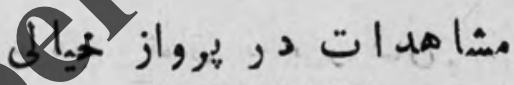

هر جند بر و بال زدلاريم حو مر غان

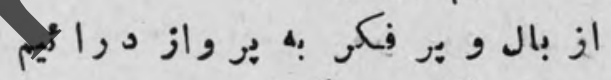

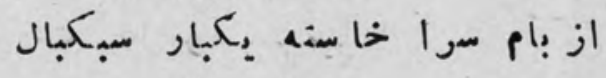

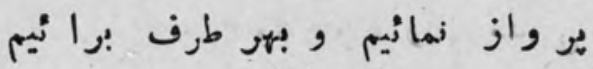

$$
\text { بر واز عجيبى .كه نظر دور كنه }
$$

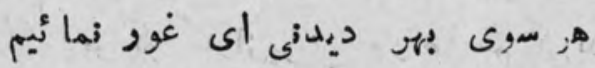


بينيم جو خود جمله كر فتار باد بار

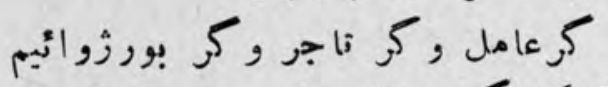

كر, 15

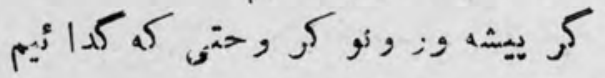

علمعاسك نظاهر زده بر بهرئ خويشيم

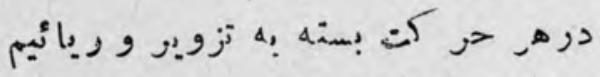

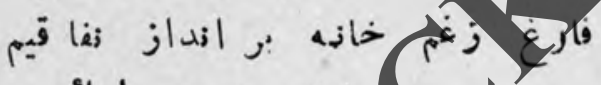

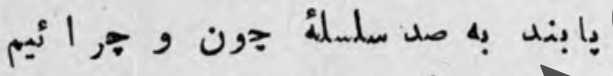

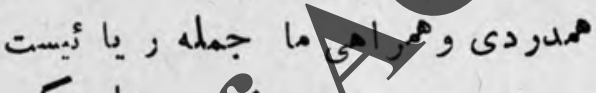

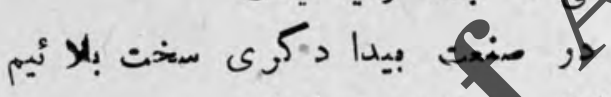

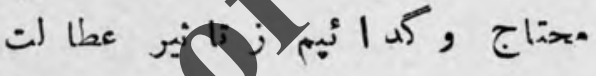

را حت طلب!

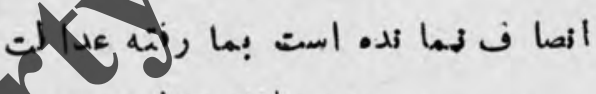

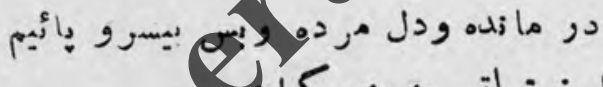

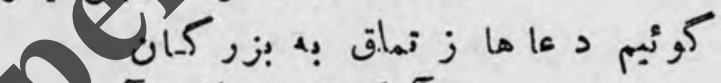

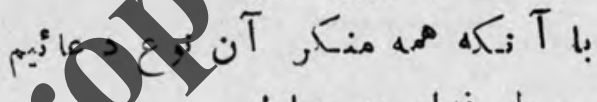

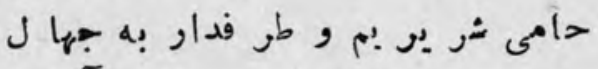

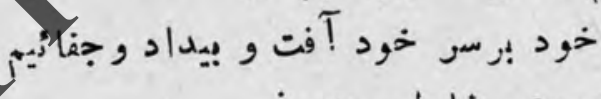

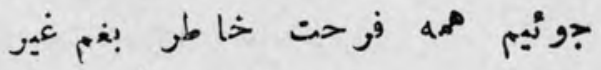

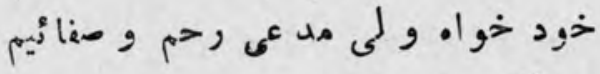

$$
\begin{aligned}
& \text { ز ئن بيثمكو واجد ازبن سير خباليت }
\end{aligned}
$$

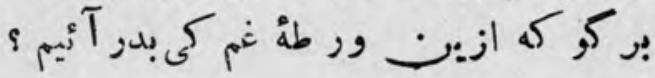




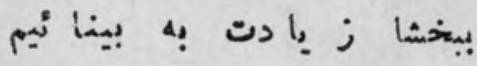
خلخها روان ساز ازذكرناهي زبان زعلم بيفرمز يارب دروان

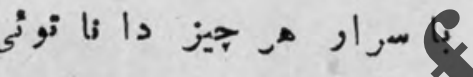

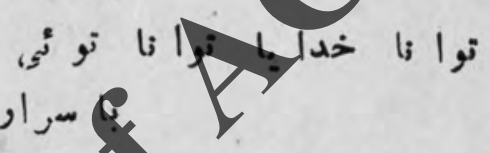
خدا با هنم بند :-1-10 نولها تونى كن عنا بت توان

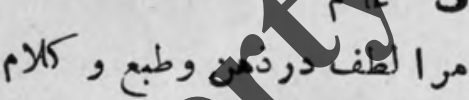
بيخشا الها ز الكان

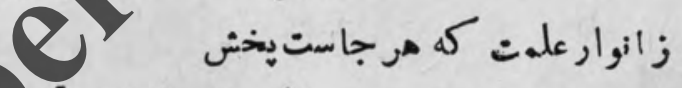

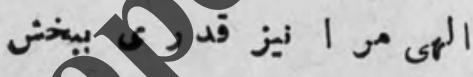
0
زمن جهل بزد اوبخث از كرم الهر المر

اتر در بيان و توان دمرمانلمان

$$
\text { كر بما كر اين التجا ميكنم }
$$

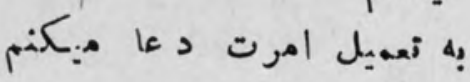

الهى بجق نو ا نا نئ

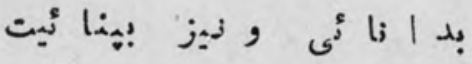




$$
=9 \cdot=
$$

ز زيروى آنم نزان يد نوان

$$
\text { كه عامى بدمكان فروز }
$$

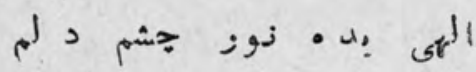

ز نكرت بكن باك آ ب وكمنم

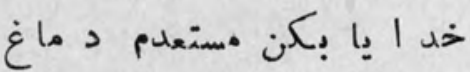

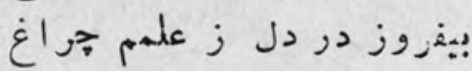

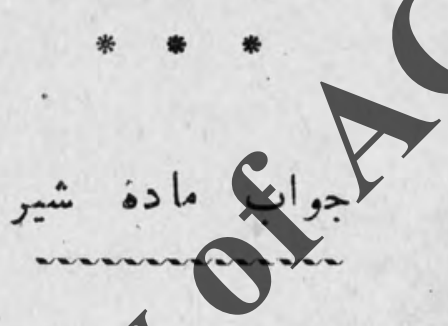

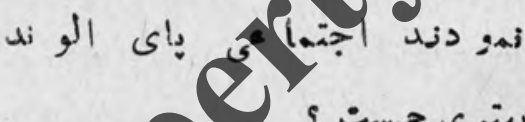

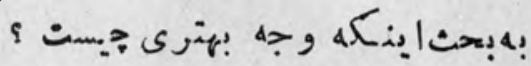

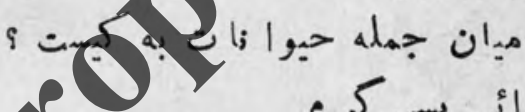

$$
\text { بشد آغاز :ور رائى بسى كرمب }
$$

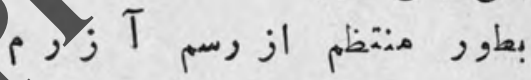

$$
\text { بنوبت كرد وصفى هر يك ازخويش }
$$

شغال وكر كا وروباه وخر وخر وميش

$$
\text { يكاكابك شرح وصف خويش بنهود }
$$

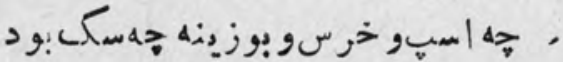




\section{ز خود لافيد هر حيوان به كفتار}

بكا بـ بك كاو و اشتر ، فيل و كمتار

$$
\text { زخود نعريف و تو صيفى نمو دى }
$$

بر ح حو بين شر حى فز و دهى

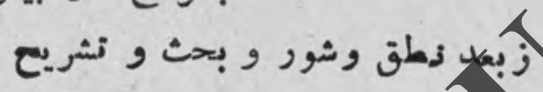

كس از ندقيق و الهتيضاح ونوضيع

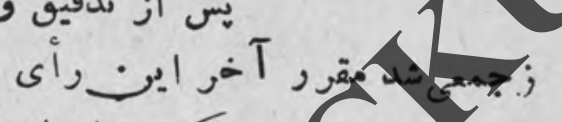

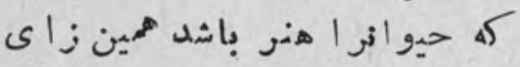

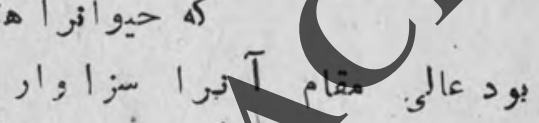

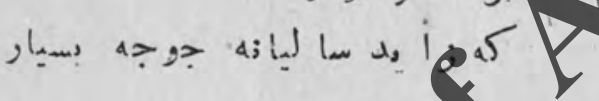

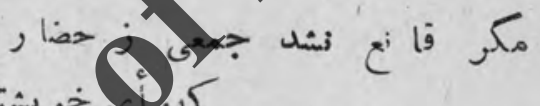

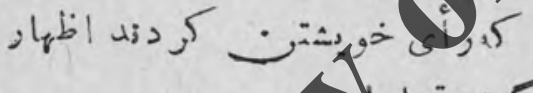

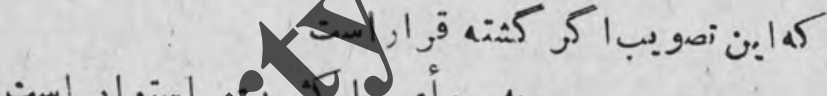

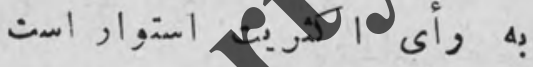

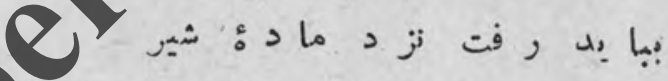

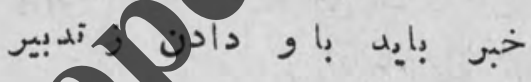
0

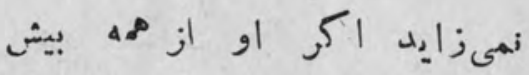

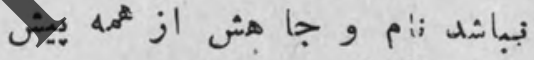

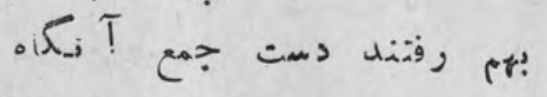

به هيث شير ما ده خواه نا خوا.

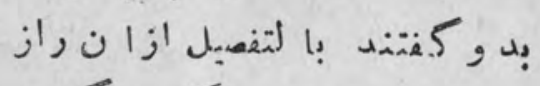

كه تاكم بد جوان جواب فيعله باز 


$$
\text { با بشا ن كنت نير ماد. غران }
$$

كه اي جمع سخن نافه内 وان ونا دان

زجندين جوجه آرودن نمرنيست

$$
\text { ز زا زيدن به بسيارى هنر زبسـ }
$$

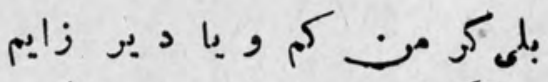

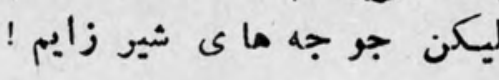

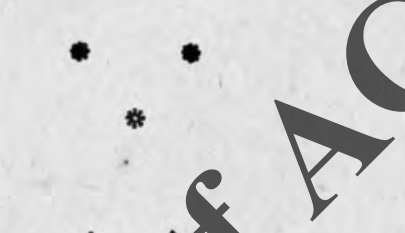

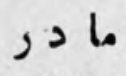

...............

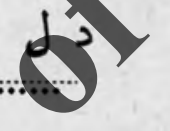

\section{stis}

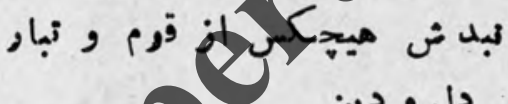

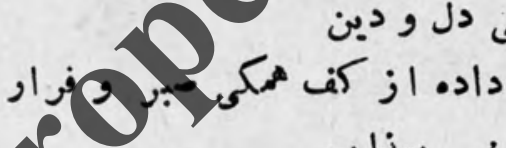

نده از شور جو الفى بعذاب إده

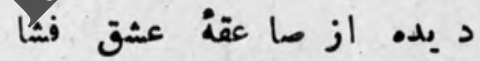

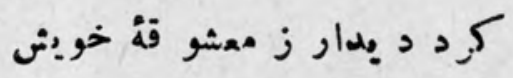

رو زي از موسم ديكوى بهار

عشق ا ظها ر بد لدا ر زمود زي

بعد ازان شككو. و : نا لث بسيار 


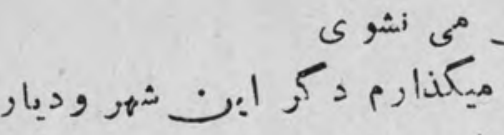

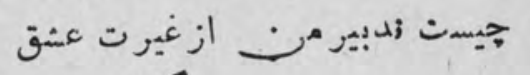

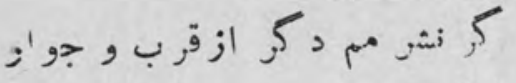

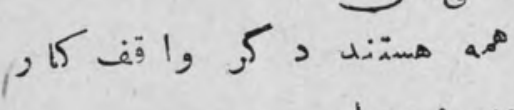

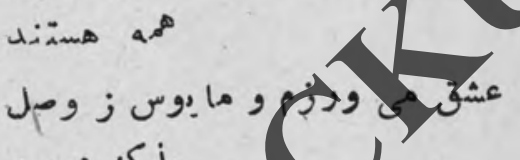

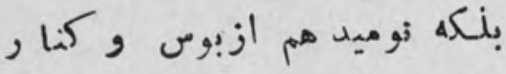

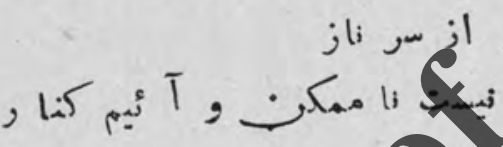

ك.5. معشو

كر ;

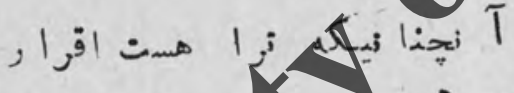

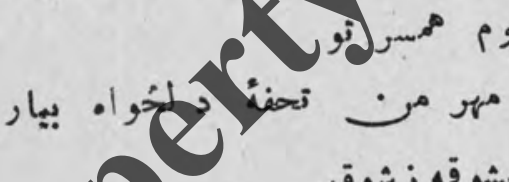

كفت د الدا ده به معشوقه زشوق

كا

$$
\text { هر جه خو اهث بودت بى كم وكاست }
$$

كثم اجرانم وكاتو بفر ماى نـكار

كفت محجبو به كه فى الفور برو آجن

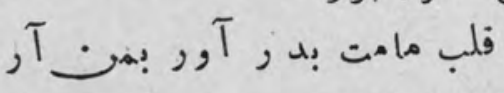

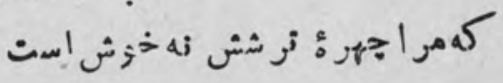

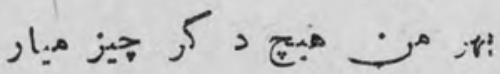


$-92=$

د كر آن بئخر, د غول د

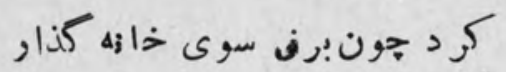

مادر بير بيك ضر ب بكشت

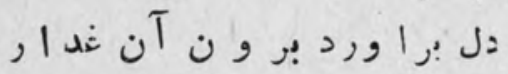

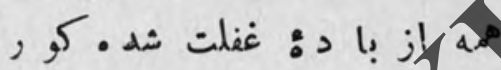

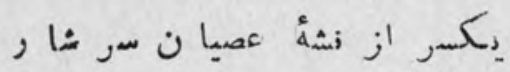

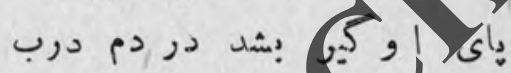

خورد برورى زمين خر بزه ورار

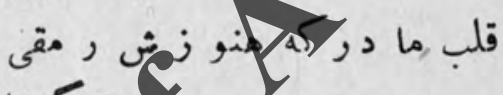

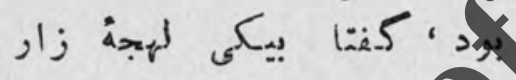

كأى

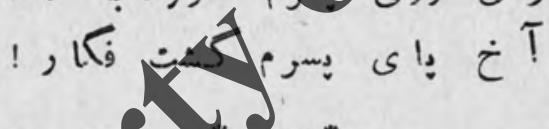

جو اب د ند ان

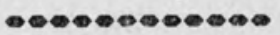

Aسد س :طرز جديد

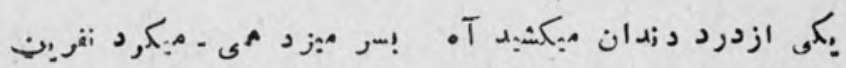

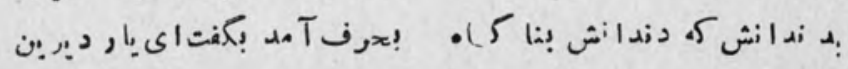

•

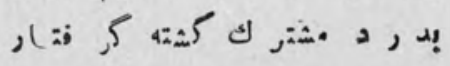




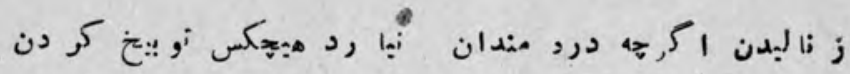

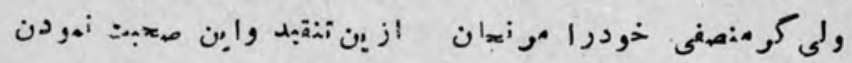

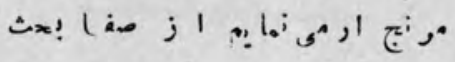

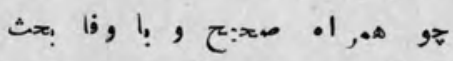

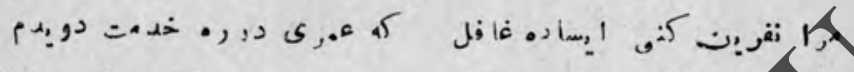

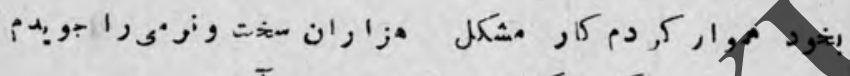

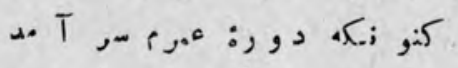

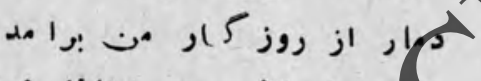

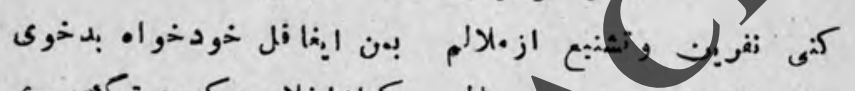

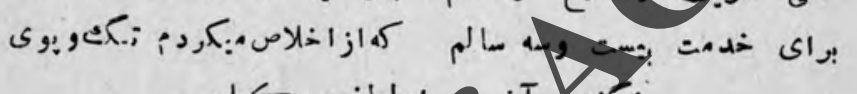
, : كنى is

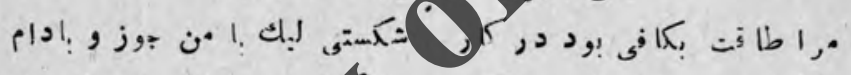

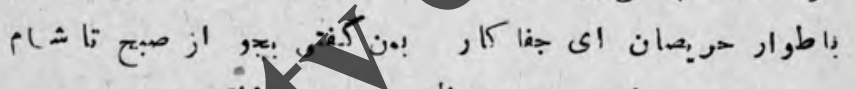

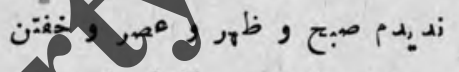

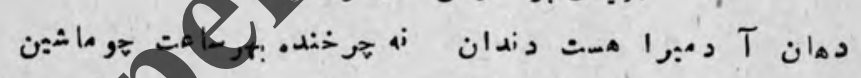

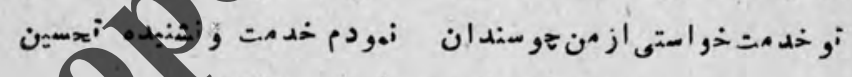

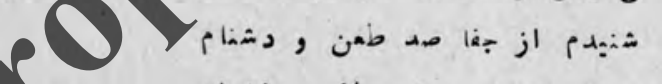
r

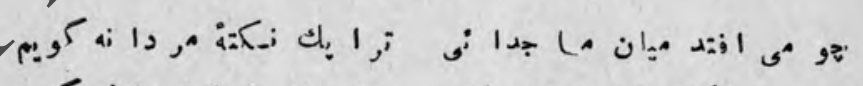

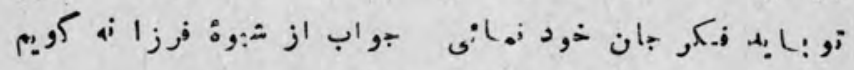

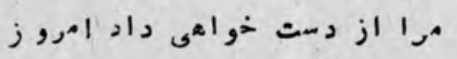

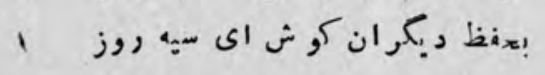

- (1) 


\section{عنو ان آ دميت

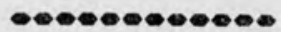

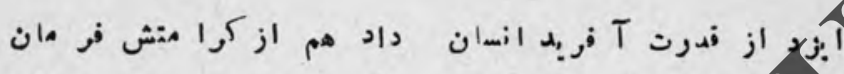

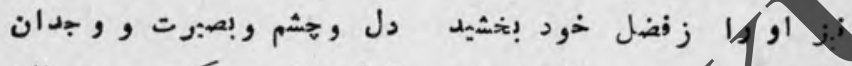

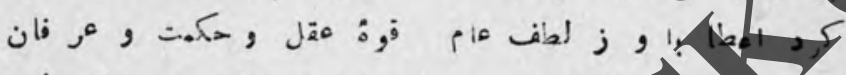

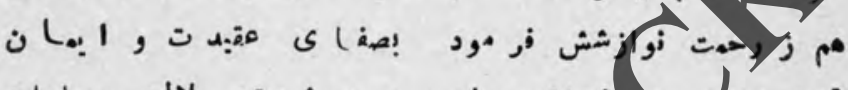

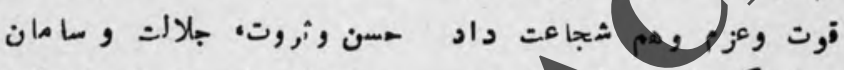

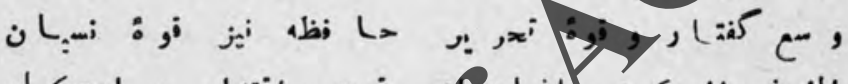

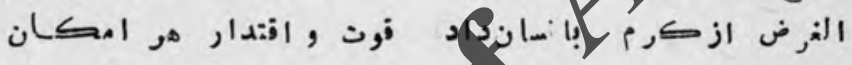

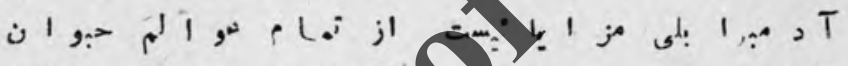

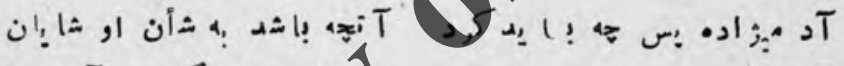

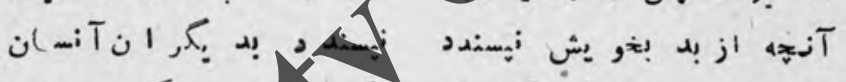

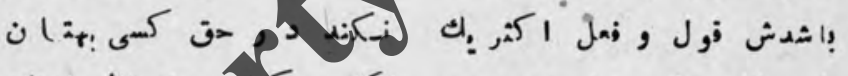

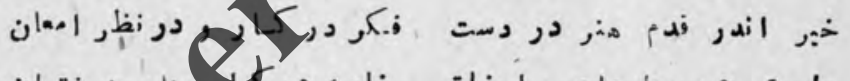

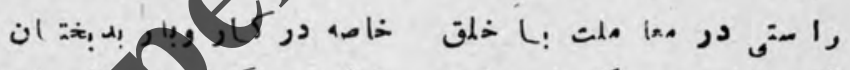

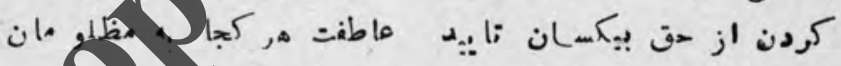

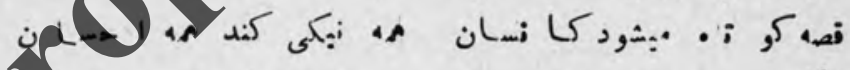

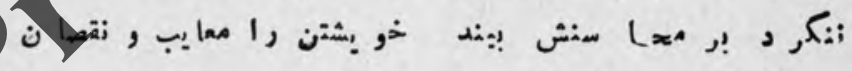

$$
\begin{aligned}
& \text { : }
\end{aligned}
$$

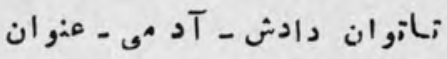

6) 


\section{دروصف خراهة شر بفة خانم الانبيا (ص)

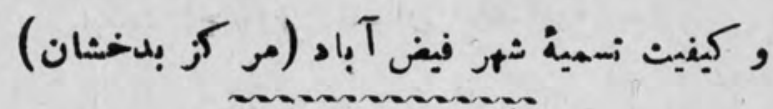

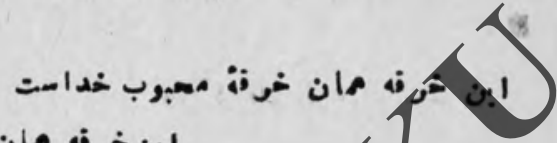

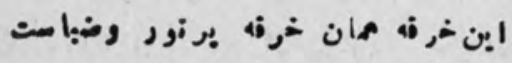

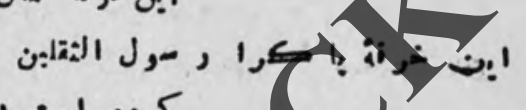

كرد. است بير بنزوا: بدر و-:نت

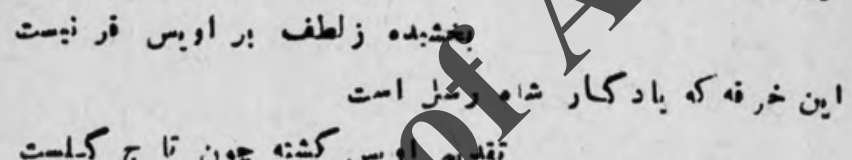

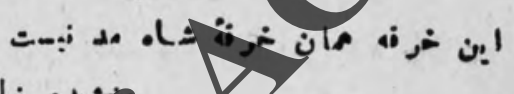

"

$$
\text { Jl- }
$$

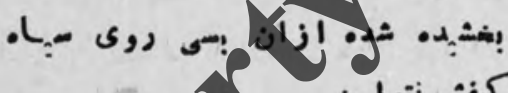

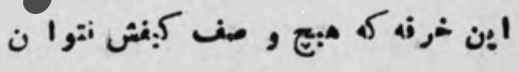

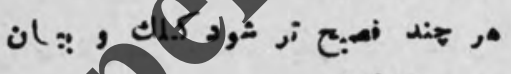

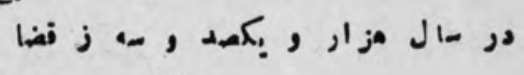

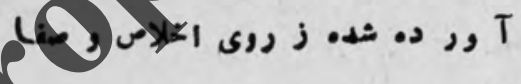

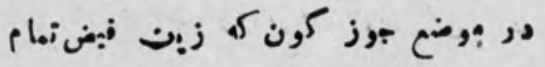

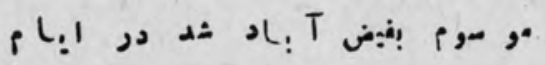

ㄴ. 


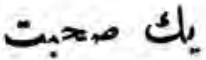

\section{زهضت اجتهاعى أسوان بك زأمه است}

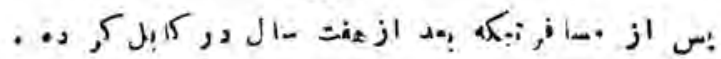

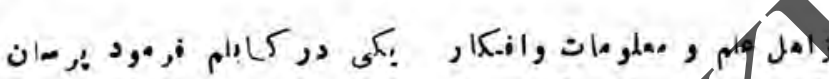

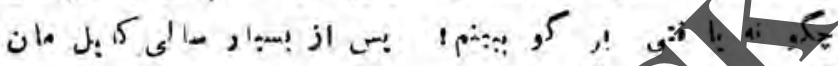

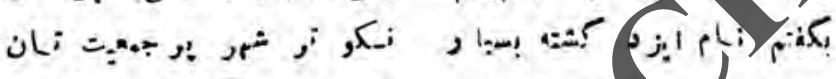

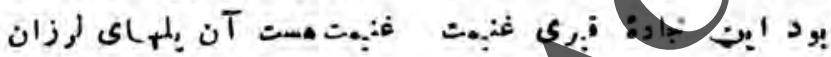

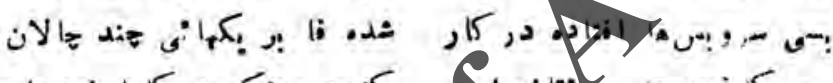

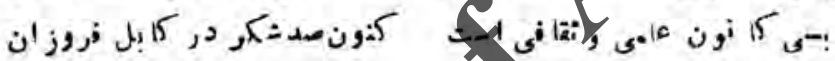

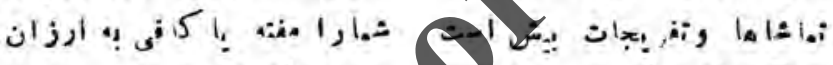

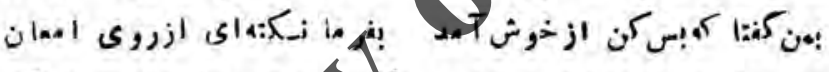

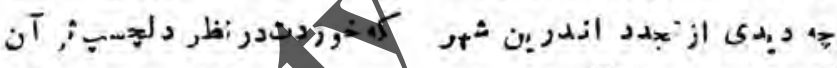

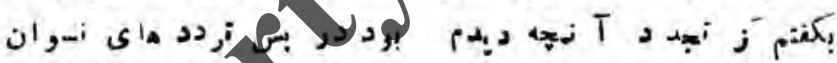

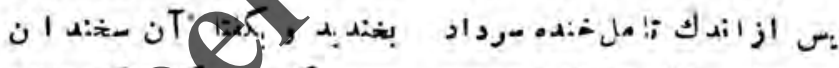

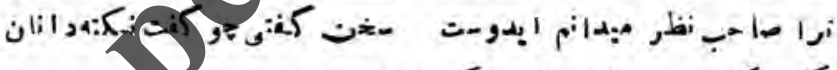

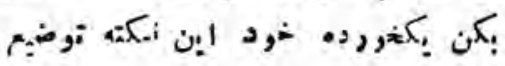

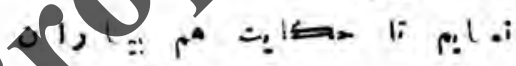

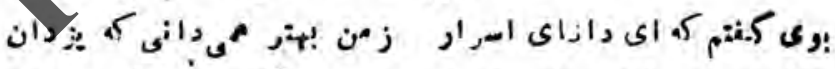

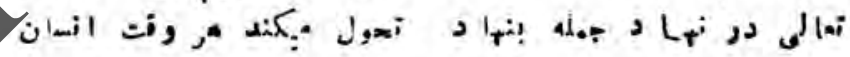

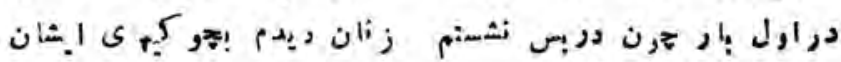

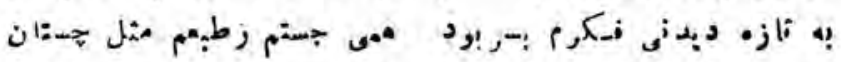

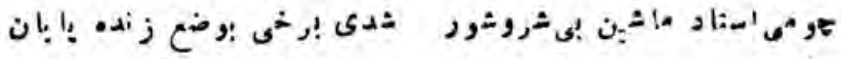

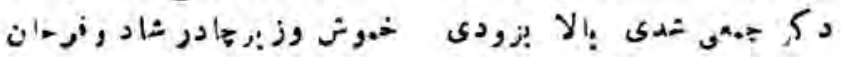




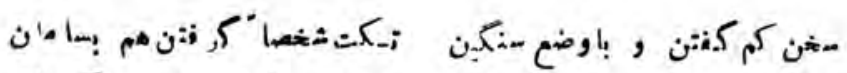

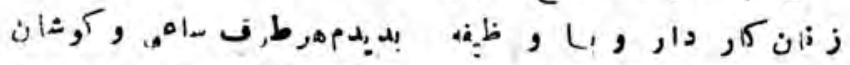

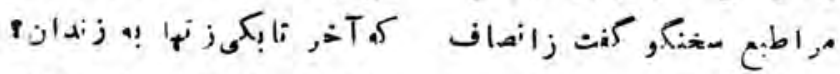
;

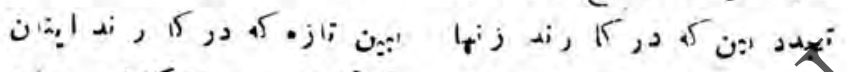

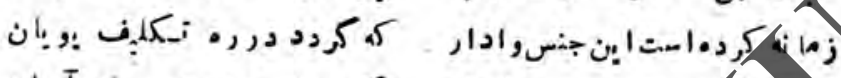

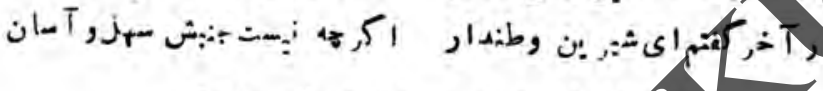

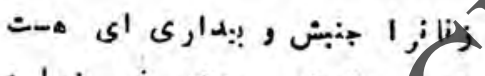

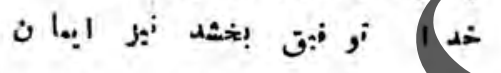

워

6

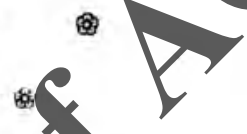

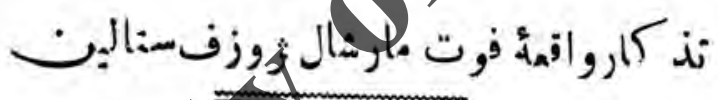

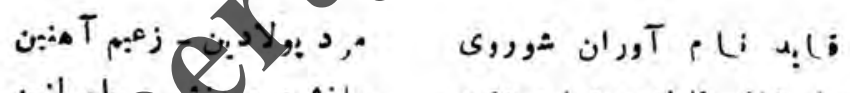

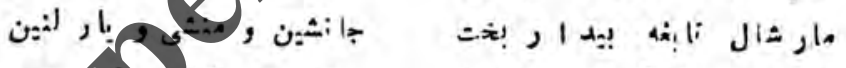

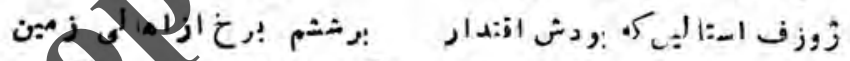
جشم يوتيد إزبهان 51 مهداجل

$$
\begin{aligned}
& \text { انجاد شور, شی شد سوكرار }
\end{aligned}
$$

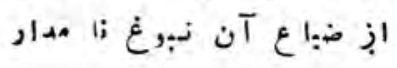

هرد رأس :أهدار ثو روى : ה در مه هالمجو إرق اف:اد شور

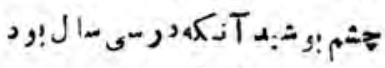

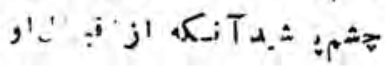




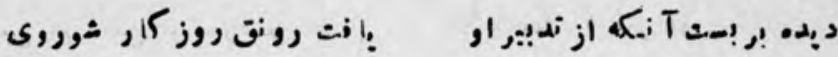

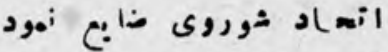

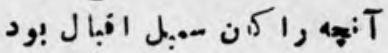

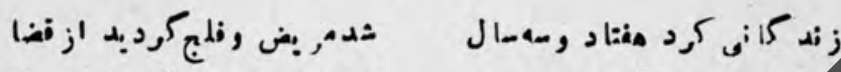

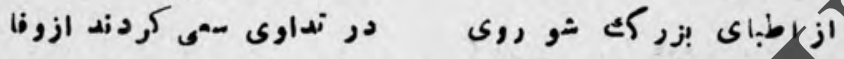

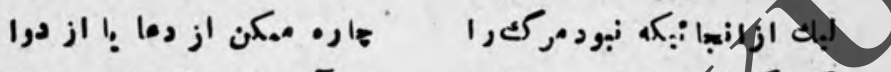

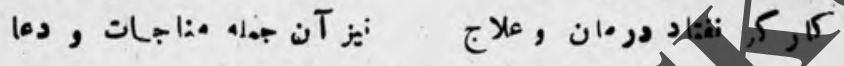

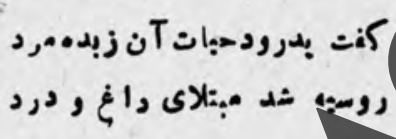

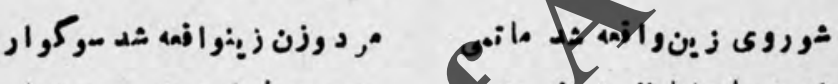

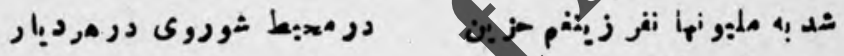

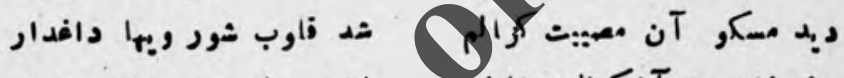

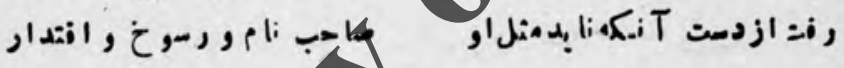

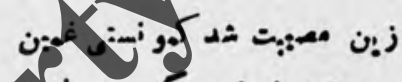

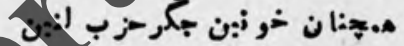

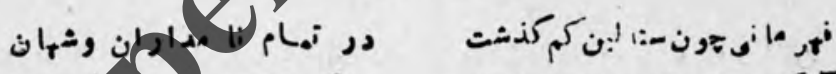

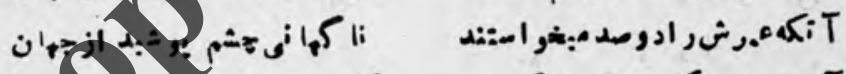

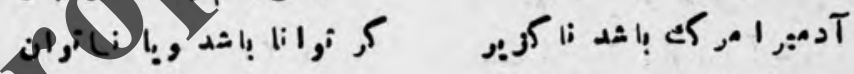

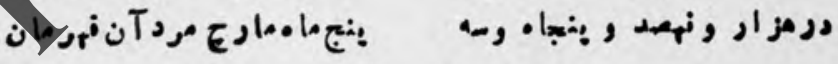

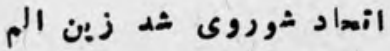

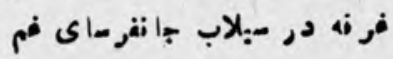




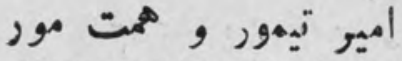

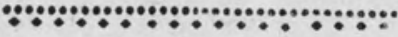

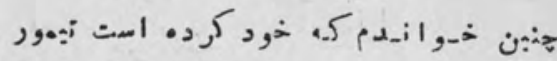

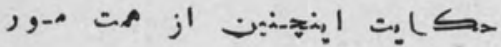

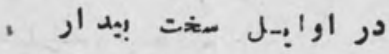

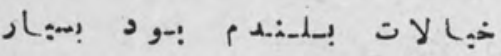

م

ه ا

;

فتو

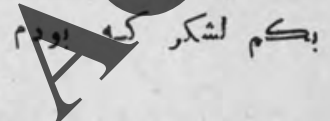

ر

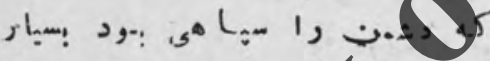

شكبر

!-

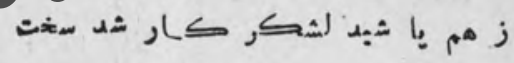

شـ

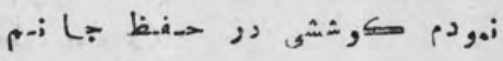

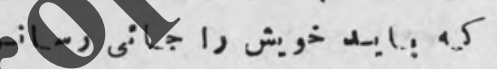

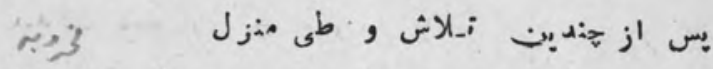

خز :

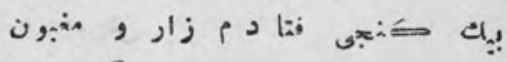

ن , j

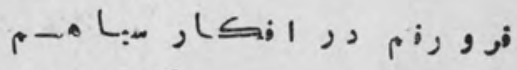

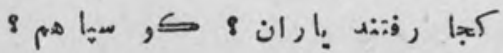




\section{$-1 \cdot r=$}

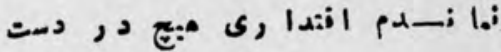

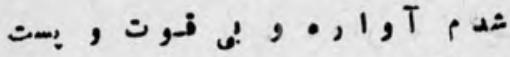

A

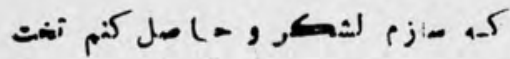

$$
\text { 飞: }
$$

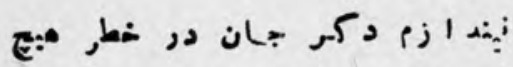

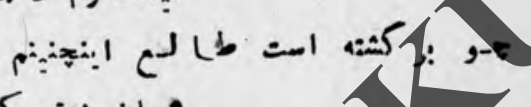

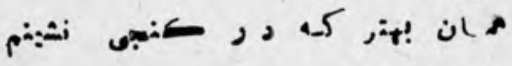

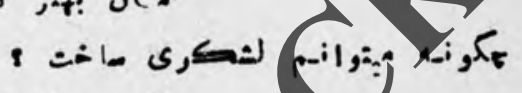

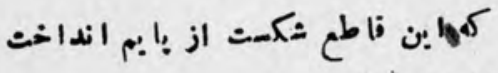

ركان

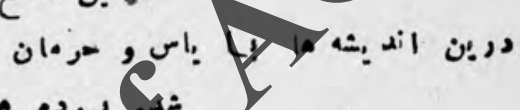

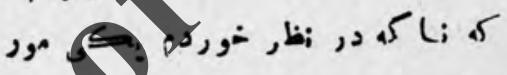

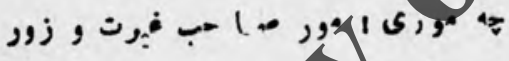

$$
\text { كر ف: }
$$

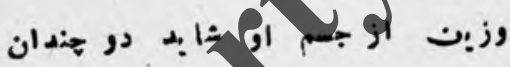

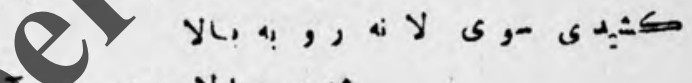

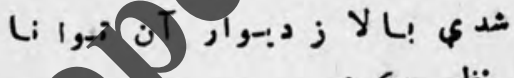

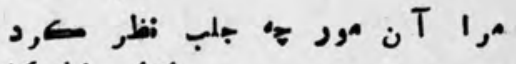

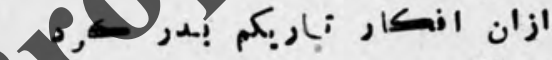

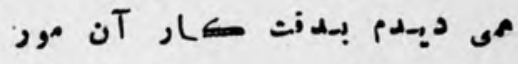

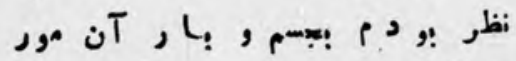

$$
\text { بm باill }
$$

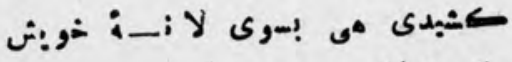

iادت از

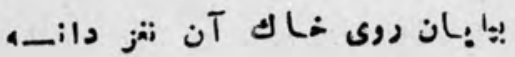




$$
\begin{aligned}
& =1 \cdot *=
\end{aligned}
$$

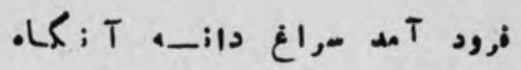

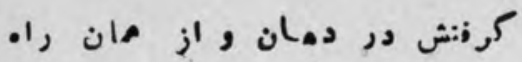

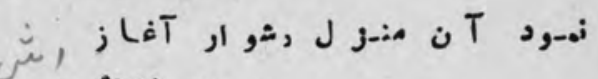

ب.

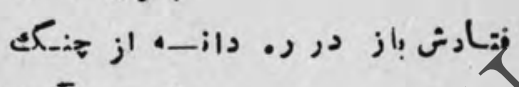

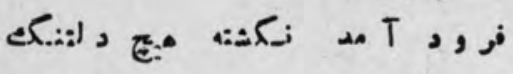

$$
\text { ك- }
$$

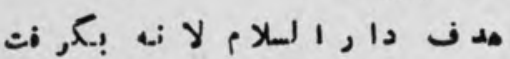

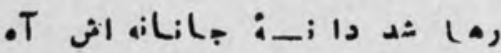

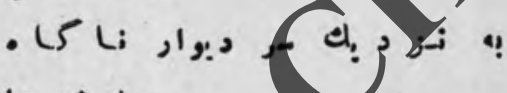

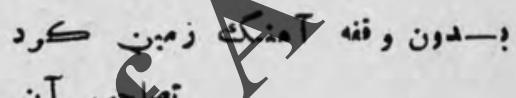

د

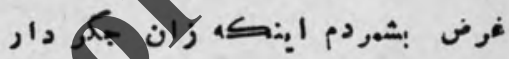

ف:

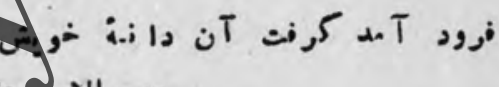

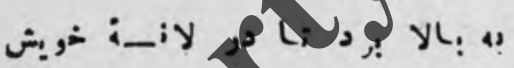

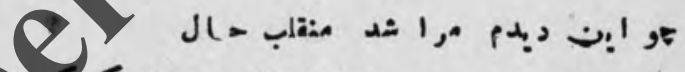

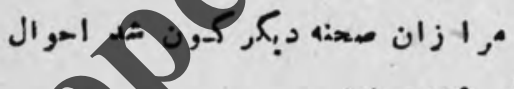

,

نز

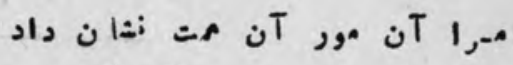

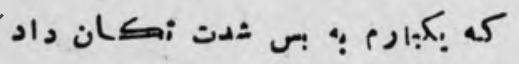

$$
\text { براهد از دل صن :اس وحرهان }
$$

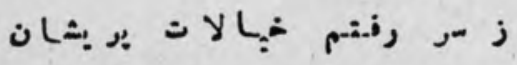

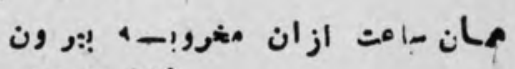

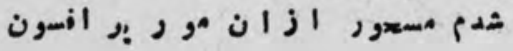




$$
-1 \cdot 5=
$$

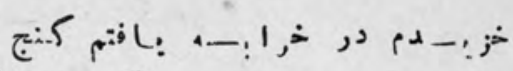

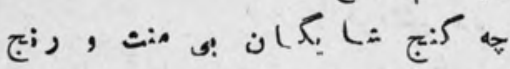

$$
\text { د ز }
$$

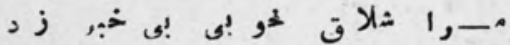

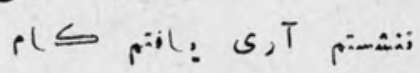

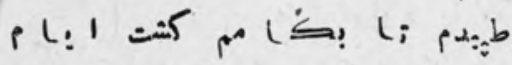

$$
\text { H, - }
$$

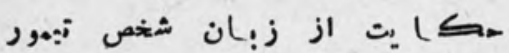

$$
\text { كثان }
$$

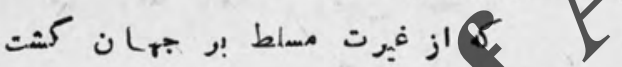

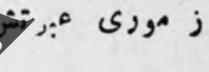

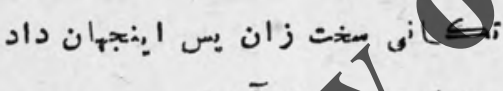

!

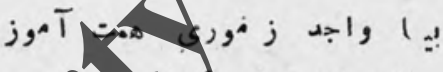

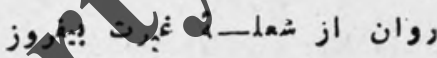

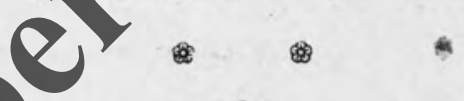

$-8$

\section{|fi}

هكو ها ر ا نشا ندار و نشان نيت

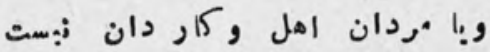

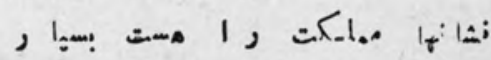

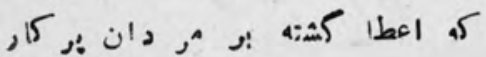




$$
=1.0=
$$

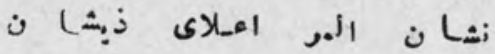

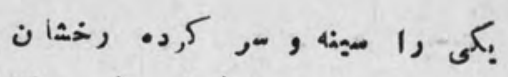

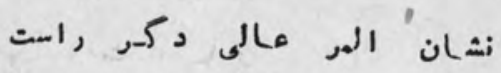

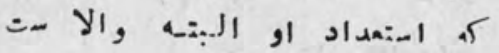

كرفة

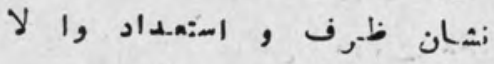

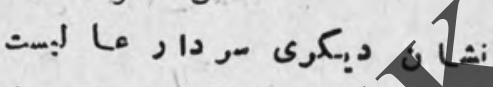

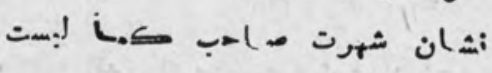

- =.

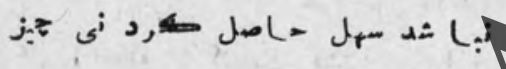

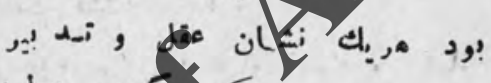

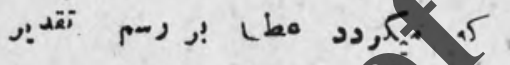

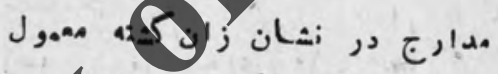

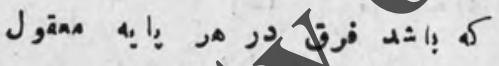

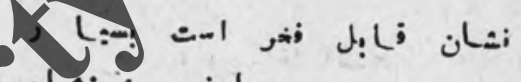

x=, مe ن

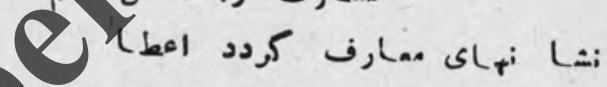

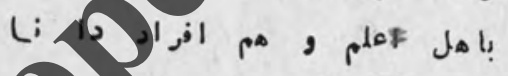

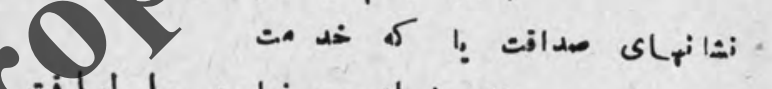

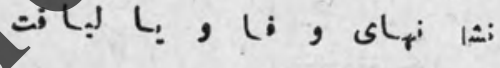

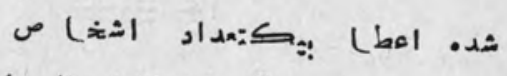

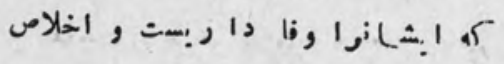

$$
\text { مدال ور ز شى آ }
$$

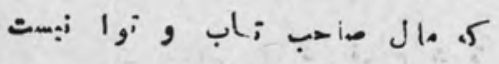

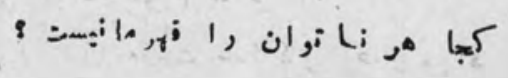




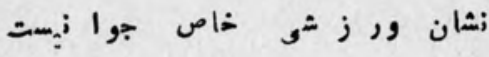

- ․

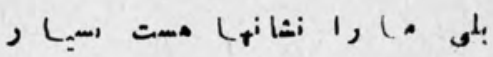

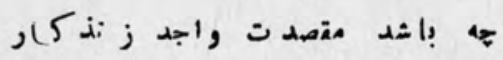

\&

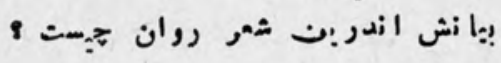

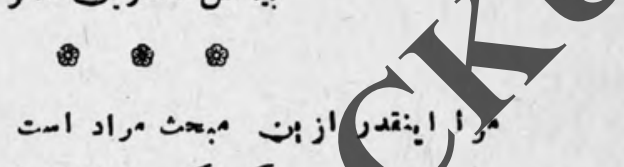

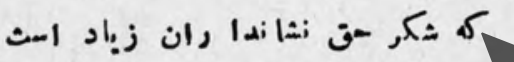

كنو is

ار

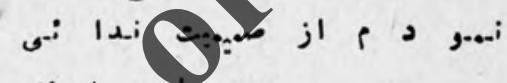

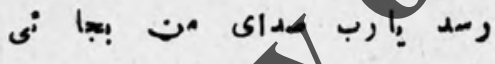

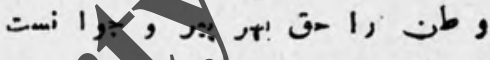

1

27 .
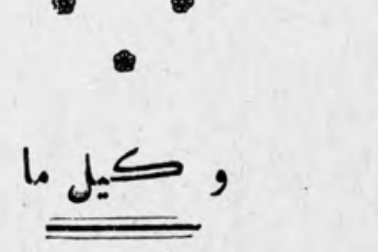

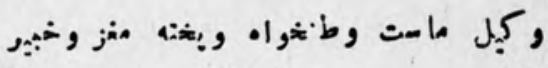

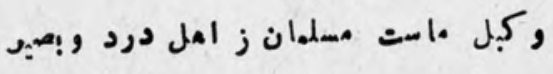

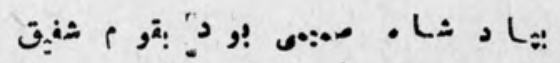

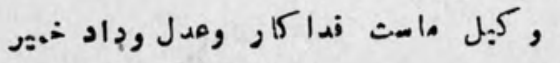




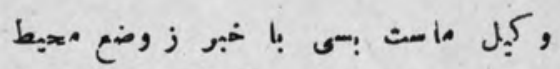

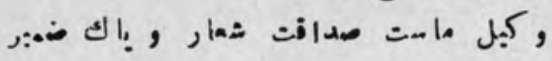

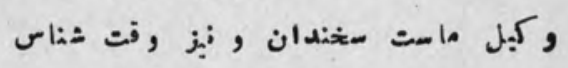

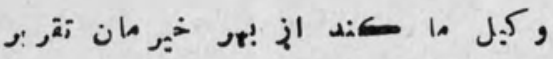

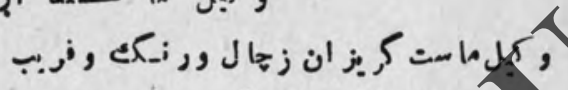

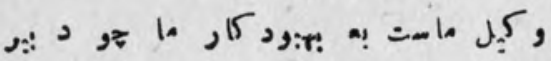

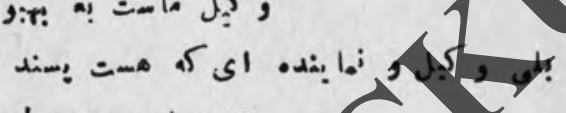

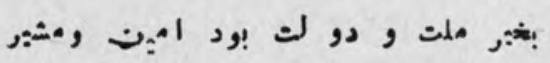

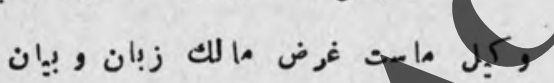

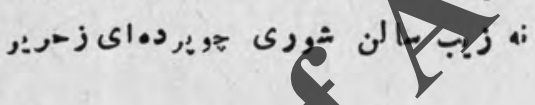

6

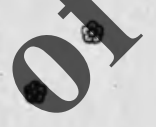

4

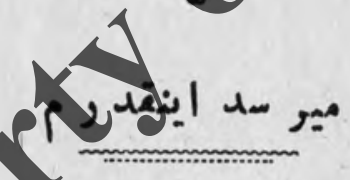

$Q \gamma$

1

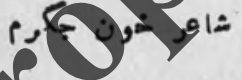

صا

p gan st:

:נورم ط?: נמו

ب :ود إن هنر م

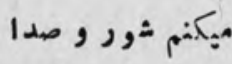

is $5,2,1,4.0$

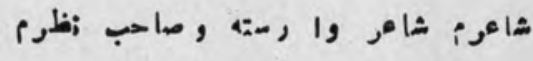

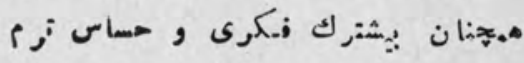

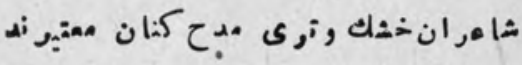
"ن

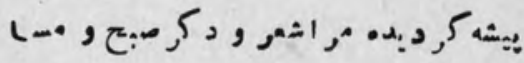

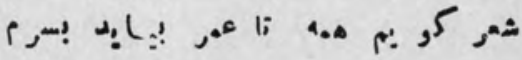

هر كاجا كو : 
ك,

;

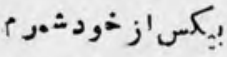

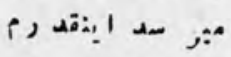

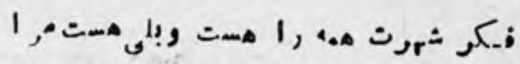

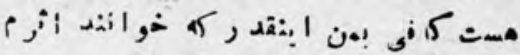

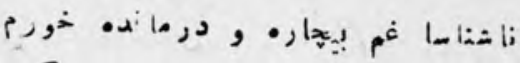

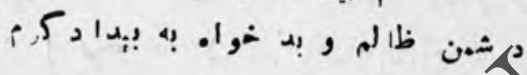

(3)

s

Tاز سال

[ ]

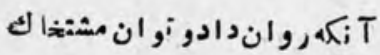

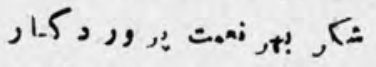

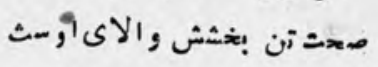
ش

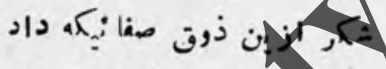

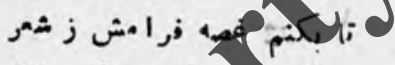

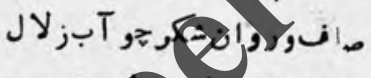
نغ شكر كنم : شكر ازبن is سال لجل

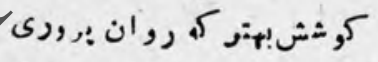

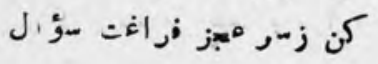

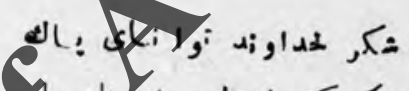

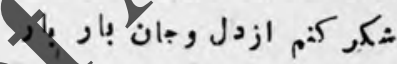

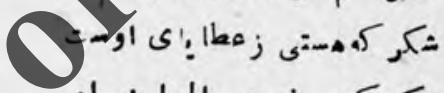

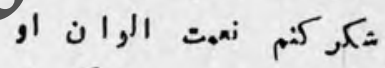

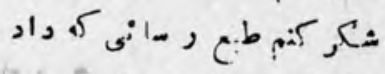

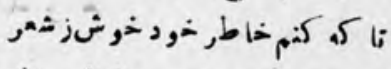

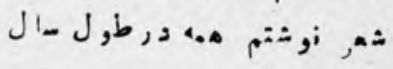

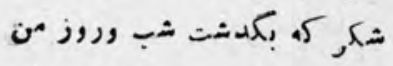

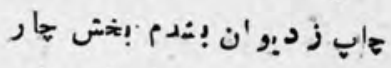

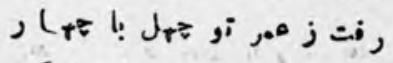

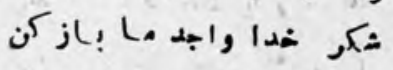

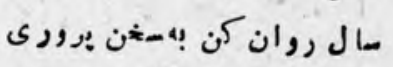

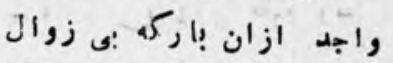

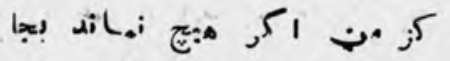

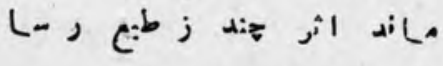

- 


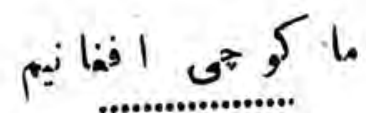

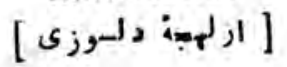

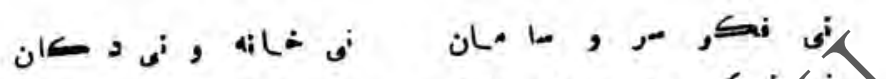

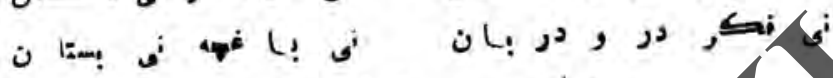

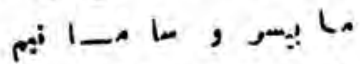
:

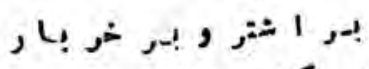
, $1-1$

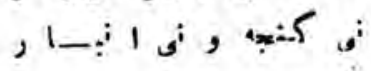
$\rightarrow 1:-1$

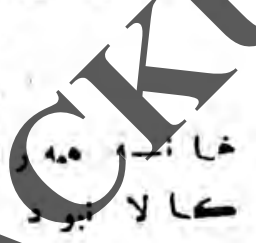

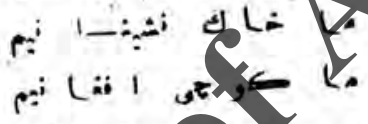

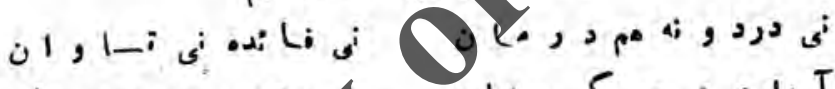

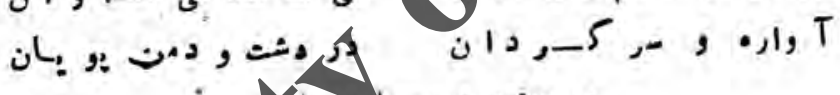
S

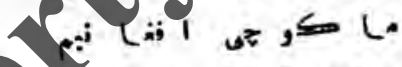

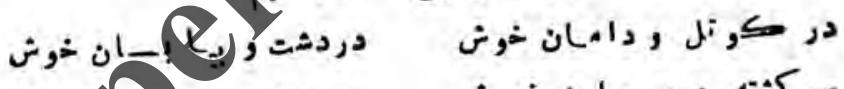

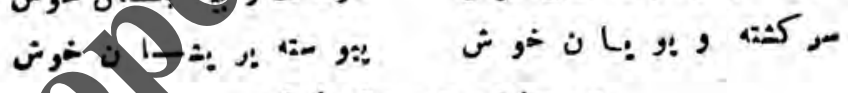
مل

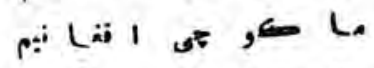

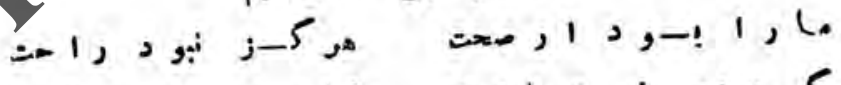

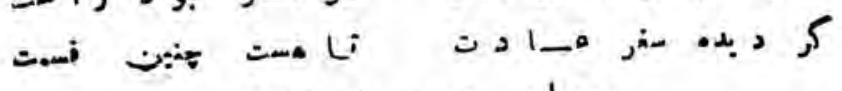

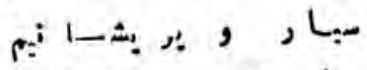
il (중 


$$
=11:=
$$

J

:::::::

يكى نا لبدى از د ست دل خوبش

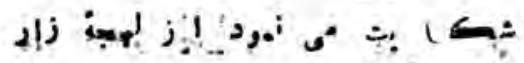

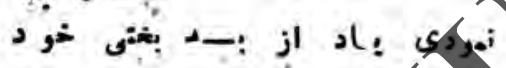

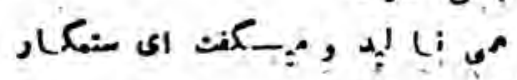

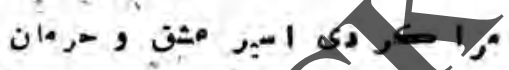

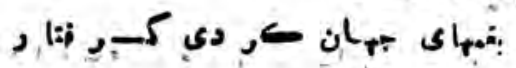

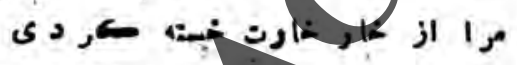

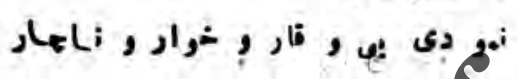

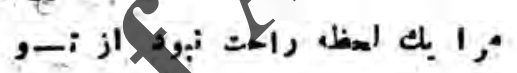

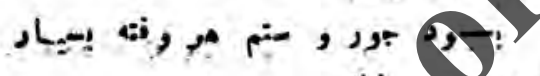

a

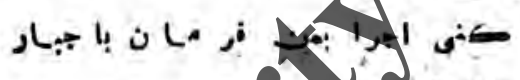

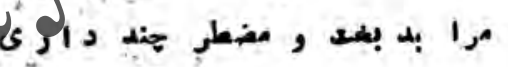

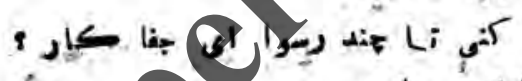

:

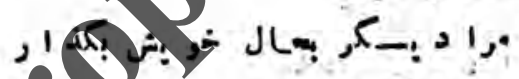

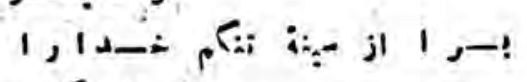

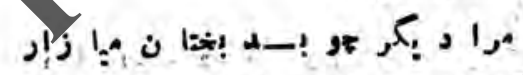

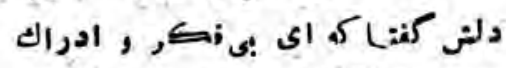

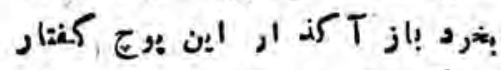

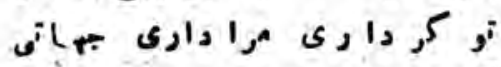

:كر, غك 


\section{غ. غل}

Con

ba

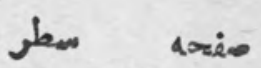

بـ

:

11

از :بن

!

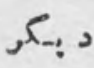

,

جوان كويد

جوان كو.بم

م,

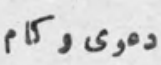

5

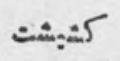

8

12

ف.

Ails

$0 \gamma^{v}$

18

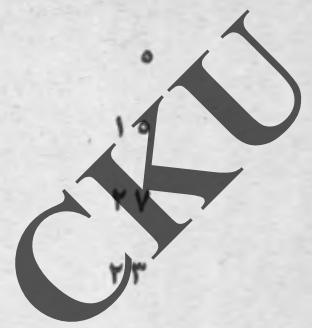

3

$2 x$

ضرور

bان

I

1

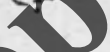

1

$\dot{T}$

re

1

rv

* $\{1$

$\iint y^{4}$ ple Jal.

لا نا

L.A

40

v

$\Lambda^{\mu}$

$y^{a} \ln L$

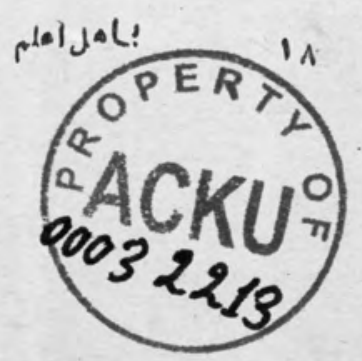

